\title{
Addressing Global Challenges through Pluralistic Sovereignty: A critique of state sovereignty as a centerpiece of international law
}

\author{
John W. Head *
}

Editor's Note: In this Article by KU Law faculty member John Head, we join global issues with Kansas issues. Professor Head explores a central concept of international law - the concept of sovereignty, as exercised by nation-states - with an eye to urging legal reforms that will help address global challenges that have special relevance to our own state. As he notes near the end of the "Introduction" to his Article, the issues he addresses bear importantly on agriculture and climate change, which are crucial to the future of Kansas. Moreover, he suggests that addressing global legal issues offers an opportunity for Kansas to add a new chapter to its "long history of progressive legal reform."

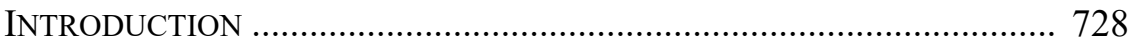

I. TOWARD A NEW ORIENTATION FOR SOVEREIGNTY ......................... 731

IA. HISTORICAL FOUNDATIONS AND THE BUILDING OF

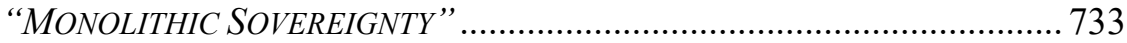

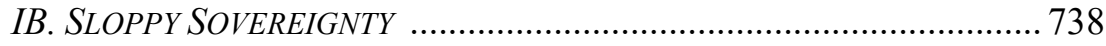

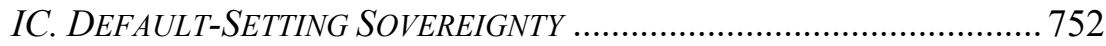

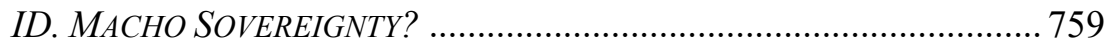

IE. SOVEREIGNTY AND STATES FROM A PRACTITIONER'S

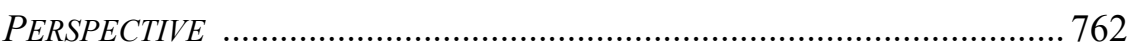

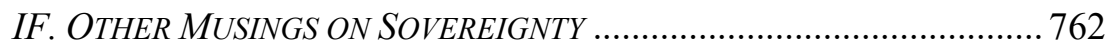

IG. NEGOTIATED INNOVATION AND PLURALISTIC SOVEREIGNTY ......... 783

II. OVERCOMING THE ANACHRONISM OF THE STATE AND

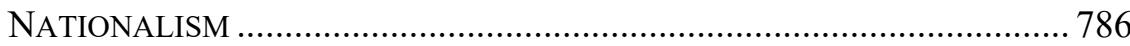

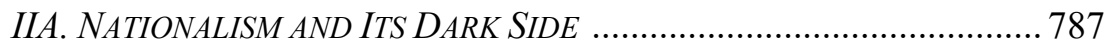

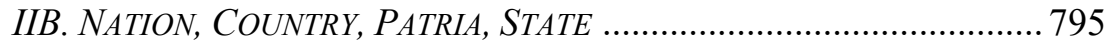

IIC. FURTHER CLARITY ON THE NATION-STATE: ALI KHAN AND

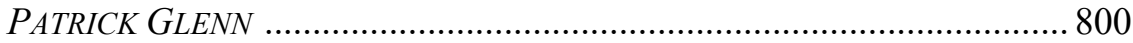

IID. TERRITORIAL INTEGRITY, OWNERSHIP, AND RESPONSIBILITY . 809

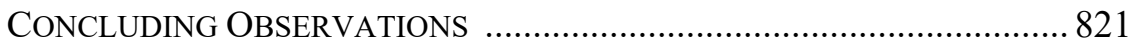




\section{INTRODUCTION}

Almost exactly twenty-five years ago, the Kansas Law Review published an article I wrote about "supranational law." Now I welcome the opportunity to publish - again in this same journal — an update on the views I expressed then, as well as a proposal for introducing a new concept for addressing global challenges we face today.

In my 1994 article, I explored international-law developments of the preceding half-century. The year 1944 served as my principal startingpoint because that year saw the emergence of the first generation of modern public international organizations (such as the International Monetary Fund), as part of a burst of enthusiasm for multilateral solutions to global problems. I offered this synopsis:

In sum, the legal landscape of the globe has changed radically in the past fifty years. It has witnessed a "multilateralization" of legal regimes, both through the rise of international organizations and through an explosion in the number and coverage of multilateral sets of rules. For better or worse, we have entered the age of "supranational law." New players and new rules have made obsolete the concept of an "international law" concerned solely or primarily with nation-states abiding by rules emanating from their own free will. ${ }^{2}$

Did I predict that "supranational law" would in fact soon become a more effective system of law than the form of international law that preceded it? No.

Barring some global catastrophe on the same order of magnitude as the two world wars of this century, I expect supranational law to continue suffering, at least for the next half-century, from two of the same problems that have dogged international law thus far and prevented it from maturing into a complete and fully effective legal system.

One of these problems is political[:] . . the doctrine of state sovereignty

\footnotetext{
* John W. Head holds the Robert W. Wagstaff Distinguished Professorship at the University of Kansas, where he concentrates on international and comparative law. His recent books include texts on global business law, on international agricultural reform, on Chinese dynastic history, on the Asian Development Bank, and on global legal regimes to protect the world's grasslands. He has also written numerous monographs, articles, and other works relating to international law, some of which have been published in Chinese and Indonesian. Mr. Head has been awarded Fulbright teaching and research fellowships to China, Italy, and Canada and has also taught in Austria, Hong Kong, Jordan, Mexico, Mongolia, Turkey, and the United Kingdom.

1. See John W. Head, Supranational Law: How the Move Toward Multilateral Solutions Is Changing the Character of "International" Law, 42 U. KAN. L. REV. 605 (1994) [hereinafter Head1994].

2. Id. at 635 .
} 
remains too strong to permit the establishment of an effective system for enforcing rules against the most powerful states. ${ }^{3}$

Is state sovereignty still "too strong" now, a quarter-century later, to permit "supranational law" to emerge and help address global problems? Yes, but only barely. My research and experience over the past twentyfive years, coupled with the ever-increasing threat posed by environmental degradation-especially climate disruption-suggest to me that state sovereignty has weakened around the world. Partly because of this weakening, I regard the prospects for "supranational law" not only more likely but perhaps inevitable in coming years.

Accordingly, I am engaged now in a project to suggest how we might undertake a reorientation of certain concepts that form the foundation of international law and governance. I give special attention in this Article to the doctrine of sovereignty and the so-called nation-state that purports to possess and exercise such sovereignty. In doing so, I emphasize how poorly certain concepts rooted in sixteenth- and seventeenth-century Europe serve the needs of today's world, and I outline how they might be modernized to make them, and us, better able to address global problems.

How do any of these topics relate to Kansas - and why am I eager to express my views in the Kansas Law Review? Three reasons spring to mind. First, among the "global problems" I referred to in general terms in the preceding paragraph, one is especially pertinent to Kansas: agriculture. In recent years, building on my own personal history of having grown up on a farm, I have concentrated most of my academic and advocacy efforts to helping escape from the dead-end of modern extractive agriculture of the sort that dominates the landscape and economy of our own state and the surrounding states of our Great Plains region. To that end, I have published several books and $\operatorname{articles}^{4}$ that (i) explain the

3. Id. at 659. The second problem I identified was that "as a physical matter, our world is all we know. It is not part of some larger population or broader legal context to which we might look for a generally recognized set of fundamental rules against which the rules of supranational law can be judged valid or invalid." Id.

4. See, e.g., John W. HeAd, Global Legal Regimes to Protect the World's Grasslands (2012); JOHN W. HEAD, INTERNATIONAL LAW AND AgROECOlOGICAL HuSBANDRY: BuILding LEgAl Foundations FOR A NEW Agriculture (2017) [hereinafter HeAD-2017]. See also John W. Head, A Global Corporate Trust For Agroecological Integrity: New Agriculture in A World of LEGITIMATE ECO-STATES (forthcoming 2019) [hereinafter HeAD2019]. For an abbreviated treatment of some of these topics, see John W. Head, International Law, Agro-Ecological Integrity, and Sovereignty - Proposals for Reform, 63 FED. LAW. 56 (2016), http://www.fedbar.org/Resources_1/Federal-Lawyer-Magazine/2016/June/Features/InternationalLaw-Agro-Ecological-Integrity-and-SovereigntyProposals-for-Reform.aspx?FT=.pdf [https://perma .cc/K5P2-WSK2] [hereinafter Head-2016]; John W. Head, Grasslands, Agriculture, and International Law: A Survey of Proposed Reforms, 26 KAN. J. L. \& PUB. POL’Y 297 (2017). 
ecological dangers I see inherent in the form of industrial agriculture that the U.S.A. has promoted for the past half-century and that now has spread around the world and (ii) explore the role that law can play in facilitating a transition to a "natural-systems" form of agriculture. ${ }^{5}$ Sovereignty-the subject of this Article - stands at the center of international law. Hence, making international law an effective means of transforming agriculture, in Kansas and elsewhere, will require a modernization of sovereignty.

Here is a second reason-related closely to the first - why I see a strong linkage between the state of Kansas and the topics I address in this Article: climate change. Just as reforming the concept of sovereignty will help international law respond to the crisis I see in agriculture, doing so will also help respond to the climate crisis. After all, Kansas faces in the next few years the prospect of substantially warmer temperatures, drier soils, and groundwater depletion, ${ }^{6}$ with serious consequences not only for agriculture but also for public water supplies and electric power generation in the state — and indeed for the health of our fellow Kansans generally, since "Kansas is likely to have four times as many days above $100^{\circ} \mathrm{F}$ " by

5. It is worth noting that from a scientific standpoint, as distinct from a legal standpoint, Kansas has for several decades led the world in developing a natural-systems agriculture of the sort that my overall research agenda aims to support. The Land Institute, founded about forty years ago with its headquarters in Salina, recently achieved commercially-viable production levels of what they call "the first perennial grain crop in the history of agriculture over 10,000 years"- a perennial intermediate wheatgrass they have named Kernza ${ }^{\circledR}$. See Tim Unruh, Gaining Momentum, SalinA J. (Aug. 4, 2018), http://www.salina.com/news/20180804/gaining-momentum [https://perma.cc/XAZ9-KF62] (last updated Sept. 3, 2018). Unlike annual grains, Kernza ${ }^{\circledR}$ does not need replanting every year, and its deep perennial roots make it highly drought tolerant and pest resistant. For details on this and other areas of progress in developing perennial-polyculture crops, see HEAD-2017, supra note 4, at 204-32.

6. See U.S. EnV'T Prot. Agency, EPA 430-F16-108, What Climate Change Means for KANSAS 1 (2016), https://www.kansasforests.org/resources/resources_docs/climate-change-ks\%202 016.pdf [https://perma.cc/2DRW-E694] [hereinafter CLIMATE-KANSAS]. As a consequence, crop yields are likely to "decline by about 50 percent in fields that can no longer be irrigated" and "[e]ven where ample water is available, higher temperatures would reduce yields of corn." Id. at 2. Numerous other reports touch on the same themes. For instance, the 2014 U.S. National Climate Assessmenttouted as a "comprehensive scientific assessment ... of climate change and its impacts across every region of America"-indicated that Kansas and other states in the Great Plains face the prospect of "more frequent and more intense droughts, heavy downpours, and heat waves." Office of the Press Secretary, White House, Fact Sheet: What Climate Change Means for Kansas and the Great Plains, OBAMA White HOUSE ARCHIVES 1-2 (2014), https://obamawhitehouse.archives.gov/sites /default/files/docs/state-reports/KANSAS NCA_2014.pdf [https://perma.cc/GL5K-4H28]. These consequences of climate change would affect not only agricultural productivity but also the health and resilience of other ecosystems (from, inter alia, "increases in wildfire activity and pest outbreaks"). $I d$. at 2 .

7. See Climate-KAnSAS, supra note 6 , at 1 . As explained there, "[a]lthough the state has only one hydroelectric dam, conventional power plants also need adequate water for cooling. Compounding the problem, rising temperatures are expected to increase the demand for electricity for air conditioning." Id. 
the year $2050 .^{8}$

I also see a third point of connection between Kansas and the topics I address in this Article. This state has a long history of progressive legal reform. Our state acted early to adopt child labor laws, to create juvenile courts, to regulate the working hours of railroad employees, and to pass a civil service law. ' Indeed, as one observer recounting our state's "long progressive tradition" has expressed it, "[t]he earliest Kansans fought off slaveholders to make their territory a free state." 10 Efforts to improve our system of governance-including at the global level, now that ours is an interconnected world - should have voice and support in Kansas; doing so could contribute another chapter in our state's history of progressive legal reform.

For these reasons, I appreciate the opportunity to examine in the following pages some issues of international law that look different today, now that twenty-five years have passed since I last addressed them here. First, I focus (in Part I of this Article) on the concept of sovereignty; then I discuss (in Part II) the closely related concept of the "nation-state." I conclude with some observations about (i) how poorly these concepts serve the needs of today's world and (ii) how the concepts might be reformed to help us address the challenges, and especially the ecological challenges, that modern society faces.

\section{TOWARD A NEW ORIENTATION FOR SOVEREIGNTY}

Countless observers have struggled to define, discuss, disparage, defend, denounce, and even deify sovereignty. Likewise, accounts of the "nation-state" abound. While some of the accounts are complimentary, many are critical. In setting the stage for a summary of my own views on the concept of sovereignty - and on its closely-related concept of the state-I offer below a broad range of perspectives on sovereignty. From these perspectives will emerge the following six main themes.

A first theme, explored in Section IA below, relates to the historical development of the concept of sovereignty. It is an old concept, rooted in the political peculiarities of sixteenth- and seventeenth-century Europe. Although the concept has changed greatly over time, it has retained the essential characteristics with which it was born roughly four hundred years

\footnotetext{
8. Id. at 2.

9. See Progressive Movement, KAN. HIST. SOC'Y (Nov. 2001), https://www.kshs.org/ kansapedia/progressive-movement/14522 [https://perma.cc/AUY4-W3F3] (last updated June 2011).

10. Conservative Shift Has Some Kansans Yearning For The Past, NAT'L PuB. Radio (Apr. 27, 2013 4:17 PM), https://www.npr.org/2013/04/27/179490501/conservative-shift-has-some-kansansyearning-for-the-past [https://perma.cc/GBM3-8J8H].
} 
ago.

A second theme, explained in Section IB below, is that sovereignty is a remarkably sloppy concept. It has changed dramatically over time. It has proven nearly impossible to define cleanly at any single stage of its development. It is liable to cast more darkness than light. And these aspects of "sloppiness" are evident not just if the concept of sovereignty is considered across several disciplines (political science, sociology, and law, for instance) but even if the concept of sovereignty is considered solely from a legal perspective.

Third, sovereignty is merely a "default setting": whatever central rules the notion(s) of sovereignty might have, those rules are by no means brittle and non-derogable; instead, they can be displaced when circumstances warrant. As I will explain below in Section IC, numerous specific modern cases illustrate how such a displacement of the standard rules of sovereignty has occurred in the modern world. Accordingly, even if we were able to settle on a definition of sovereignty - thereby overcoming the problem of its "sloppiness"-we would still not be hide-bound; departures from the standard form of sovereignty have been widely accepted where specific needs have arisen. Only in the absence of imagination and resourcefulness does traditional sovereignty serve as a very restrictive default setting.

Fourth, we can and should discount and reject popular claims of sovereignty that frequently appear in the popular press and political rhetoric - what I call "macho sovereignty." In order to explain this point, I will briefly highlight in Section ID some such "macho sovereignty" claims and then explain why they should hold no relevance for the proper consideration of how we can use the doctrine of sovereignty in today's world.

Fifth, perhaps the greatest impediment to developing a more modern, useful, and sophisticated concept of sovereignty-one emerging from innovations designed to help overcome its sloppiness and to counteract "macho sovereignty"- -lies in the persistent view that states should and do still dominate today's political world. In this respect I will examine in Section IE a "practitioner's perspective" on sovereignty and suggest how that perspective might be modified by closer attention to recent world developments.

Sixth, even though sovereignty has deep deficiencies, it lives on as a term whose meaning we can, with some careful thought, fashion in a way that serves us well in today's world. It is with this in mind that I introduce at the end of Part I the notion of "pluralistic sovereignty."

These musings on sovereignty draw from a wide variety of published 
works. I should emphasize, though, that I have not tried to be comprehensive in this effort, but instead representative. That is, I have summarized below some key points made in a broad range of works addressing issues of sovereignty. Then, having offered those observations, I widen my discussion in Part II to encompass other closely related concepts - namely, the state, nationalism, patria, and territorial integrity.

Why? The overall aim of this Article, as noted at its outset, is to explain how poorly these time-worn concepts and definitionssovereignty, the state, and so forth-serve the needs of the modern world, especially in the face of existential threats to its natural systems. Against this critical backdrop, I intend to propose progressive and achievable reforms in international law and institutions, with special attention to agricultural reform and effective ecological governance. I will touch on those proposals at the end of this Article and develop them more fully elsewhere. ${ }^{11}$

\section{IA. Historical Foundations and the Building of "Monolithic Sovereignty"}

In my 1994 article, I explained that the historical development of our modern concept of sovereignty reflected political peculiarities prevailing in Western Europe several centuries ago, ${ }^{12}$ resulting in what I have more recently called "monolithic sovereignty." 13 Let me summarize as follows the main points I have emphasized in my earlier accounts: ${ }^{14}$

- "Sovereignty is both a historical and a legal concept. That is, an understanding of the concept of sovereignty as it prevails in today's world requires both (i) as a historical matter, an appreciation for how a cluster of key factors has influenced the development of international relations, especially in the Western world, and (ii) as a legal matter, an appreciation for the central position that sovereignty is thought to occupy in the world's legal framework." 15

- Jean Bodin, Hugo Grotius, and Thomas Hobbes had special

\footnotetext{
11. See generally HEAD-2019, supra note 4.

12. See Head-1994, supra note 1, at 612-20.

13. I first introduced this term about two years ago. See HEAD-2017, supra note 4, at 353. In another context, I have used the term "thick sovereignty" in lieu of "monolithic sovereignty." See Head-2016, supra note 4, at 62 .

14. These points draw especially from HEAD-2017, supra note 4, at 354-68. Extensive citations to authority appear in those pages for the points that I briefly summarize here.

15. Id. at 354 .
} 
influence in shaping the concept of sovereignty. ${ }^{16}$ Writing in the sixteenth century, Bodin envisioned sovereignty as a form of control that was highly centralized but that nevertheless made a king bound by external law, including natural law. Grotius, writing in the early seventeenth century, likewise gave special legal significance to natural law as drawn from Christian teaching, but Grotius went on to acknowledge as well the significance of the newly-emerged "nation-states" in the system of law. ${ }^{17}$ What might be called "the Grotian Solution" 18 was in essence a formula defining international law - or what was at the time referred to as "the law of nations"-in this way: "the law of nations = jus gentium voluntarium + natural law." 19 Hobbes, by contrast, "injected much more absolutism into the concept of sovereignty" when he addressed the subject in the mid-seventeenth century. He thereby set in position a central legal pillar for the international community, "that of state sovereignty. In doing so, he demoted natural law from its place of central prominence and promoted the single human sovereign, acting under a presumed divine right of kings, to a position of sole 'holder' of sovereignty." 20

- "All of these developments came against the backdrop of a specific set of challenges arising in a peculiar historical and political environment"-present in the sixteenth and seventeenth centuries - "that involved intense religious antagonisms and growing nationalism in the post-feudal political system" of what we now identify as Western and

\footnotetext{
16. See id. at $357-62$.

17. Id.

18. Various writers have coined the terms "Grotian Tradition," "Grotian Quest," "Grotian Moment," and so forth. See HEAD-2017, supra note 4, at 385-86. One set of authors, citing Richard Falk and others, refers to the "Grotian Moment" as "a period of normative uncertainty in which [an old structure] of international relations is being superseded, but not yet fully or in any precisely defined direction or manner." BURNS H. WESTON et al., INTERNATIONAL LAW AND WORLD ORDER 1086-87 (2d ed. 1990). More recently, Michael Scharf explored the notion of a "Grotian Moment," defining it as "a transformative development in which new rules and doctrines of customary international law emerge with unusual rapidity and acceptance." Michael P. Scharf, Seizing the "Grotian Moment": Accelerated Formation of Customary International Law in Times of Fundamental Change, 43 CORNELl INT'L L. J. 439, 444 (2010) (citing work by Saul Mendlovitz and Merav Datan). See also Michael P. Scharf, Customary InTERnational LaW in Times of Fundamental Change: RECOGNIZING GROTIAN MOMENTS (2013).
}

19. HEAD-2017, supra note 4, at 361.

20. Id. 
Central Europe. $^{21}$

- Later writers modified the concept of sovereignty to make it more absolutist in nature. ${ }^{22}$ Hence, "traditional international law had evolved by the first part of the twentieth century into a body of rules that (i) acknowledged and supported the primacy of the state endowed with a very robust form of sovereignty and (ii) consisted only of those rules that had been accepted by states, either by treaty or through practice."23 Thus was state sovereignty - construed as guaranteeing the complete legal independence of states - confirmed in its role as the central pillar of international law. ${ }^{24}$

- To a large degree, this view of sovereignty persists today in the twenty-first century. ${ }^{25}$ Granted, there are several important ways in which departures from this view have been made in the past seventy-five years or so. ${ }^{26}$ Certain topics have been carved out of the authority of states and made subject to more "external" control, especially as exercised by international organizations that have free-standing legal personality but whose powers are nevertheless heavily dependent on a cluster of states that created them and dominate them still. ${ }^{27}$ Human rights can be viewed as an example of this "carving-out." 28

- In short, our world in the early portion of this century largely embraces what I call a "monolithic sovereignty" concept. ${ }^{29}$ This "monolithic sovereignty" is territorial in its conception, so that within a single (usually contiguous) physical territory, the government of a state is thought to have nearly unimpeded authority. Moreover, the "monolithic sovereignty" concept is national in its assertion (or pretension) that state territorial boundaries widely reflect "nationalities," so that persons residing within State A are of one nationality and persons residing within State B are of another nationality. Support for

\footnotetext{
21. Id.

22. See id. at 364-67.

23. Id. at 366 .

24. $I d$.

25. $I d$.

26. Id. at 366-67.

27. Id. at $368-73$.

28. See id.

29. Id. at $367-68$.
} 
these views of sovereignty remains strong despite their inconsistency with reality in several important respects. ${ }^{30}$

In order to illustrate several of those points, I also offered in my 2017 book several diagrams ${ }^{31}$ intended to reflect in a simplified way various views of sovereignty, especially those espoused by Grotius, Hobbes, and later writers favoring a more absolutist approach — and including also some recent developments showing the "carving out" that I noted just above (as, for example, in respect of human rights norms). The diagrams, which I show below in updated form in Figures 1 and 2, reflect answers to these questions:

- What are the topics (regarding law, governance, etc.) that are the subjects of the sovereignty at issue?

- What types of entities (that is, persons, groups, etc.) are the "holders" of sovereignty in the sense that they have standing, authority, stake, voice, or vote to make decisions on those topics - or at least have the right to have their interests represented and protected by others?

- What entities are most closely involved in or responsible for implementation of such decisions - that is, for ensuring that the rules are really followed?

30. Id.

31. See HEAD-2017, supra note 4, at 362, 370. 


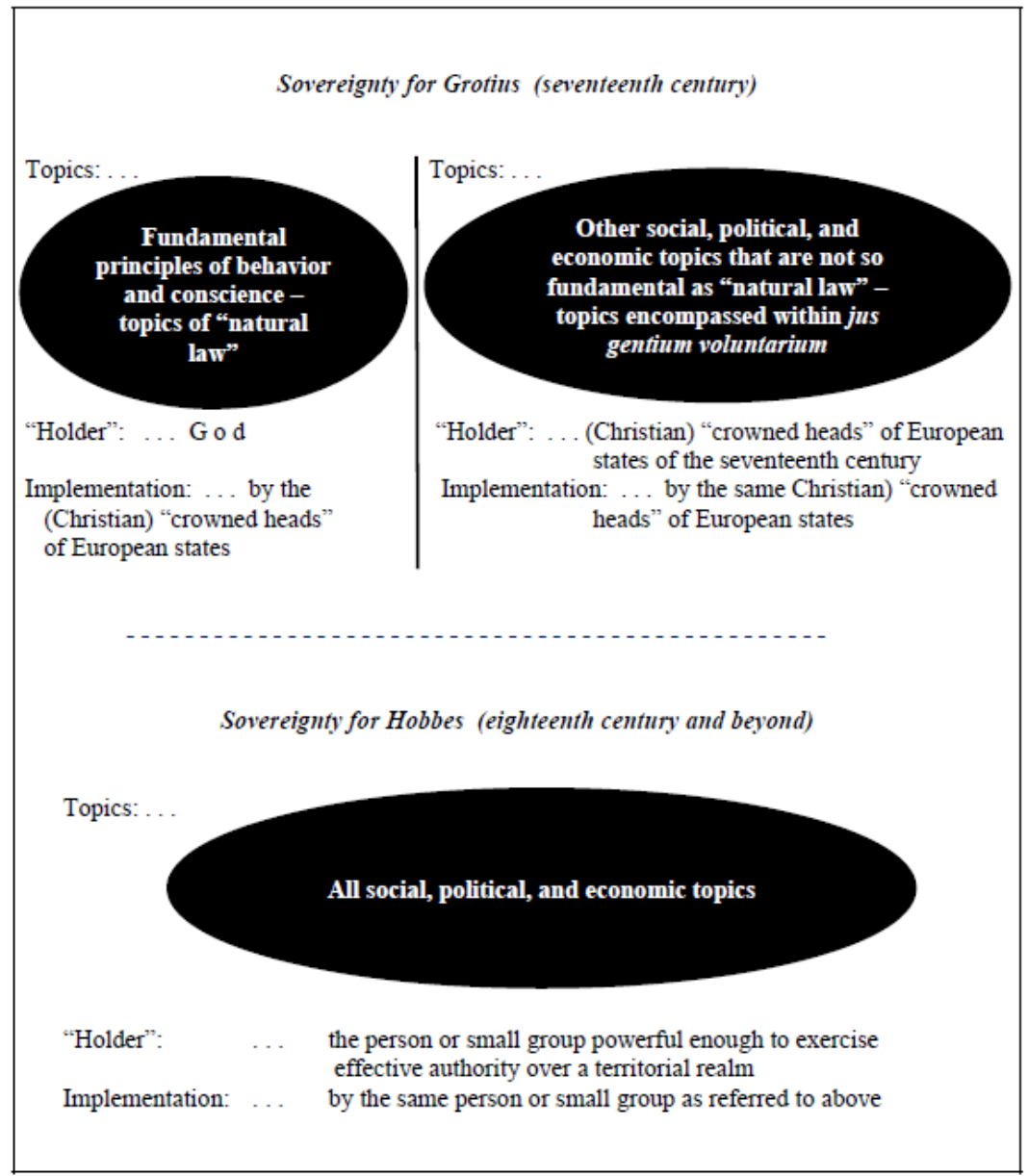

Figure 1. Simplified Representations of Sovereignty for Grotius and for Hobbes 


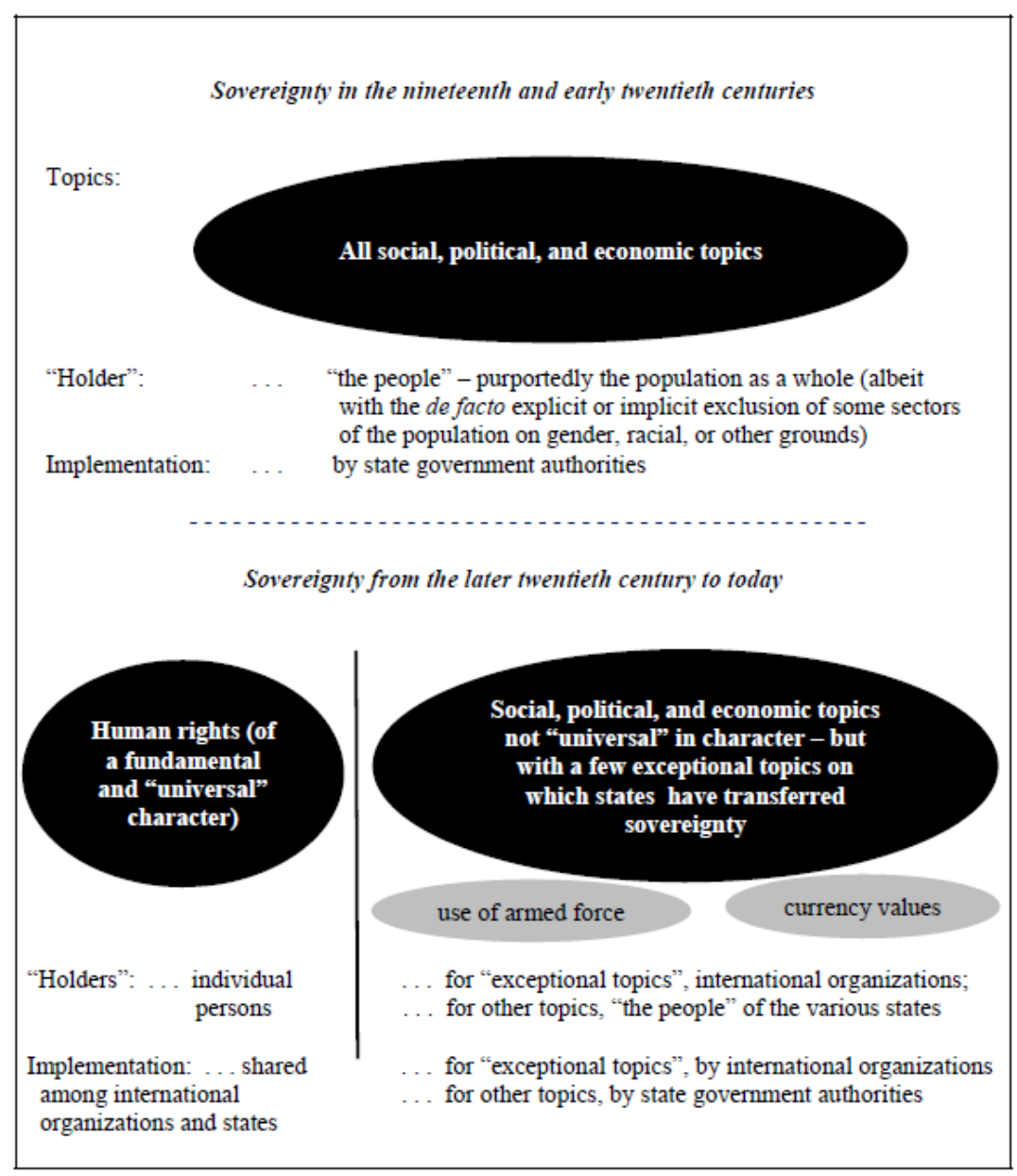

Figure 2. Simplified Representations of Sovereignty as Evolved from the Nineteenth Century to Today

\section{IB. Sloppy Sovereignty}

The summary I have offered immediately above reflects general observations that I made in my earlier writings. A closer review of the broad academic and practical literature on the concept of sovereignty yields a more complex and nuanced answer to the question "What is sovereignty?" In the following several pages I provide highlights from such a review. The first highlight is that sovereignty is "sloppy" in the sense that its meaning is remarkably vague and varying. 
IB1. Bartelson: Sovereignty, Fire, and Accidents of History

In his 1995 work titled A Genealogy of Sovereignty, Jens Bartelson of the University of Stockholm provides a critical analysis and conceptual history of sovereignty. ${ }^{32}$ Why? Because the concept of sovereignty "is central to international relations theory and theories of state formation, and [it] provides the foundation of the conventional separation of modern politics into domestic and international spheres."33 Bartelson's book deals with that separation as reflected in philosophical and political texts during three periods: the Renaissance, the Classical Age, and Modernity. ${ }^{34}$ One of his key assertions is that "sovereignty should be regarded as a concept contingent upon, rather than fundamental to, political science and its history." 35

In taking this approach, Bartelson echoes the works of numerous other writers, several of whose views are also summarized in the following pages of this Article. Under such headings as "deconstructing sovereignty" and "the end of sovereignty," Bartelson throws considerable doubt on just how and why the concept of sovereignty has come to occupy such a central role in political philosophy and (more recently) political science. ${ }^{36}$ He opens the book with a comparison of sovereignty and fire:

In speaking of something as an object, we are generally inclined to think that we are objective about it, but because we chose it in the first place, there is a possibility that the object of our choice reveals more about us than we do about it. Take fire: since prehistory, fire has been available to human experience as a datum. Still, despite the apparent uniformity of the objective phenomenon of fire, it is close to impossible to discern a corresponding uniformity in the accounts of fire since antiquity. From ancient teachings on the elements, through medieval alchemy to earlymodern phlogiston theory, fire is an object of knowledge, yet the accounts of it vary to the point of incommensurability. More puzzling, when the question of fire is raised today, one is likely to discover that fire no longer is a reality for science; there is a theory of combustion, but whenever the original question is posed, answers are likely to repeat the most ancient and most fanciful explanations. In modern textbooks in physics, it is as if fire did not exist.

Yet [even] if fire does not exist, we still speak and act as if it did. The same goes for sovereignty. For all that we know, most human societies have confronted problems of power and authority, and where they should

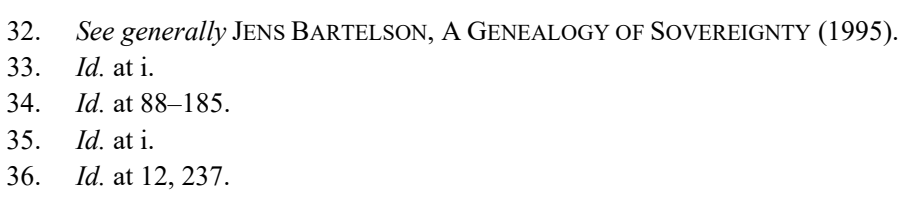


be located .... [In Europe, for instance,] we can discern how the source and locus of authority is distributed downwards in a slow chronological series, ranging from God to king, and then from king to people. Yet our textbooks in political science have become increasingly silent on the topic of sovereignty; ... [in recent years] the question of sovereignty [has been only] seldom raised, and when it occasionally has been, answers tend uncritically to repeat premodern or early-modern formulae, or to sociologize it away as reminiscent of a bygone age.

So perhaps we should do to sovereignty what Gaston Bachelard, a physicist who turned to literary criticism, did to fire; we should avoid the direct question of what sovereignty is, and instead ask how it has been spoken of and known throughout a period of time, and connect the answer to this question with the question of why it seems so difficult to speak of and to know sovereignty today. ${ }^{37}$

The approach Bartelson takes to the concept of sovereignty, therefore, is historical, genealogical, ${ }^{38}$ and philosophical. Importantly, although he does not attempt a definition per se, he pointedly disagrees with writers who suggest that "the question of sovereignty can be brushed aside as irrelevant to modern political science." 39 After all, it is indisputable that "modern political reality has the state as one of its constituent parts, however intangible and porous it seems," and "when the political scientist stumbles upon the state as a unit of analysis, ... he will once again become entangled in a discourse on sovereignty as its defining property; for what makes a state a state?"40

Ultimately, Bartelson concludes that views of sovereignty are extremely malleable, and they change with changing political circumstances. He writes: "I will insist that the relationship between the very term sovereignty, the concept of sovereignty and the reality of sovereignty is historically open, contingent and unstable." ${ }^{41}$

Having established the parameters and goals of his undertaking, Bartelson concentrates on sovereignty's conceptual history. In this regard, he argues that "most features we hold to be integral to the modern concept of sovereignty are absent from political knowledge during [the later

37. Id. at 3-4 (emphasis added) (drawing on a 1938 work by Gaston Bachelard on the "psychoanalysis" of fire. See GASTON BACHELARD, LA PSYCHANALYSE DU FEU (Librairie Gallimard, 1938)).

38. Bartelson explains that "genealogy is a history of the present in terms of its past" and that "a genealogy has not as its task to tell what actually happened in the past, but to describe how the present became logically possible." Id. at 7, 8 .
39. Id. at 1
40. Id.
41. Id. at 2 . 
Middle Ages and the Renaissance]."42 Likewise, he asserts that although the notion of sovereignty emerging in the seventeenth and eighteenth centuries (what Bartelson refers to as the Classical Age) "contains a rudiment of what we mean by sovereignty today, it nevertheless excludes certain features of sovereignty.... [that] modern... accounts of sovereignty" regard as "trans-historical[]" in character. ${ }^{43}$ In short, sovereignty has constantly changed over time in definition and in operation.

He goes much further than that, though. The most interesting parts of Bartelson's book are (i) the passages that explain how the concept of sovereignty is by nature virtually impossible to define even at any single point in time and (ii) the passages in which Bartelson suggests that with the knowledge revolution of our present age, the notion of sovereignty might essentially evaporate.

On that first point, Bartelson emphasizes that "the centrality of the concept of sovereignty in modern political discourse has enabled it to soak up a multitude of meanings," with such a "resulting ambiguity" as to make the concept highly immune to clear and useful definition. ${ }^{44}$ In this regard, he acknowledges that there is in fact one undisputed component of a general understanding of sovereignty: sovereignty is inextricably intertwined with the state and with the international system:

[W]hat makes a state a state? What is the crucial property behind its capacity for unitary action? What distinguishes it from other forms of political organization? ... [S]overeignty is introduced both as the defining property of the state and in explaining the presence of an international system. ${ }^{45}$

As evidence of the fact that this central two-part character of sovereignty is widely accepted, Bartelson cites numerous writers who claim that international politics came into being when medieval Christendom dissolved and the modern sovereign state was born, and that sovereignty lies at the basis of all international relations. He quotes Hedley Bull in this regard:

The starting point of international relations is the existence of states, or independent political communities, each of which possesses a government and asserts sovereignty in relation to a particular portion of

\footnotetext{
42. Id. at 11 .

43. $I d$.

44. Id. at 14

45. Id. at $22-23$.
} 
the earth's surface and a particular segment of the human population. On the one hand, states assert, in relation to this territory and population, what may be called internal sovereignty, which means supremacy over all other authorities within that territory and population. On the other hand, they assert what may be called external sovereignty, by which is meant not supremacy but independence of outside authorities. ${ }^{46}$

With that quoted passage from Bull, along with others, Bartelson emphasizes how the concept of sovereignty generally helps explain the essential difference between domestic politics and international politics. He quotes another authority for an explanation of why such a difference can persist - and why, as a consequence, the sovereignty of states (with its emphasis on internal monopoly of power yet external independence from other powers) is acceptable:

The state of nature among men is a monstrous impossibility ... [and so] governments establish the conditions for peace [and are] at the same time the precondition of society. The state of nature that continues to prevail among states often [also] produces monstrous behavior but so far has not made life itself impossible. ${ }^{47}$

Beyond those quite vague and generally-agreed-upon points, Bartelson explains, the term sovereignty (and, by extension, the concept of the state) are almost hopelessly confused-not just changing over time but logically muddled in any single period. He disparages, for instance, the efforts by Jean Bodin (referred to above) ${ }^{48}$ in formulating a theory of sovereignty; ${ }^{49}$ he cites Niccolo Machiavelli's "troubled attempt at innovation" in explaining the independent existence of the state against the backdrop of universalist assumptions derived from the Christian myth $;^{50}$ and he refers to Franciso de Vitoria's "inability to disentangle the state from divine law." 51

It is with those observations - particularly the ones highlighting what Bartelson calls "man's estrangement from the Christian God" of earlier days - that Bartelson starts drawing his analysis to a close. ${ }^{52}$ Under the heading "[t]he end of sovereignty," he offers these observations about how

46. Id. at 23 (quoting Hedley Bull, The AnARChical Society: A Study Of Order IN WORLD POLITICS 8 (1977)).

47. Id. at 25 (emphasis added) (quoting KenNeth N. Waltz, Man the State, AND War: A THEORETICAL ANALYSIS 227-28 (1959)).

48. See supra note 18 and accompanying text.

49. Bartelson calls Bodin's theory of sovereignty "utterly problematic" as a logical matter. Bartelson, supra note 32, at 142 .

50. Id. at 242.

51. Id.

52. Id. at 243 . 
the genealogy of sovereignty reflects unpredictable and even accidental historical developments:

Interpreted from the vantage point of nostalgia, the above genealogy would indicate a fall from the primordial beauty of Christian unity, whereas interpreted from the vantage point of a modernized historical process, it would look like a progressive series, in which man becomes the master of his own political destiny by emancipating himself from dogma and superstition.... [However, interpreted from a more discerning vantage point,] the genealogical series [of views on sovereignty] appears as a more or less random succession of discursive and epistemic events ... [that reveal] no meaning, just pure contingency. The question how did we get here [to our current view of sovereignty] ... would then be given a most prosaic answer, like the questions of how we came to wear the kind of clothes we are wearing, or how we came to eat the kind of food we are eating. ... Thus interpreted, the simultaneous rise of the modern sovereign state and the international system ... would appear quite accidental. ... .

[In short, the] modern notion of sovereignty does not result from the fulfilment of Enlightenment promises of revolution and emancipation, nor from the failure to realize these promises. Nor is the modern concept of sovereignty singularly reducible to the organic thought of historicism; rather, it emerges as the unintended consequences of the clash between the core concepts and forces of modern knowledge, ... between philosophy and history. ${ }^{53}$

Bartelson offers then a concluding suggestion. With the knowledge revolution of our present age, he asserts, the notion of sovereignty might essentially wither away as unimportant:

[S]overeignty does not merely mean different things during different periods ...; rather, the topic of sovereignty - the concept of sovereignty as opened to definitional change across time - is so rigorously intertwined with the conditions of knowing, that we could inductively expect a change in the former [the concept of sovereignty] to go hand in hand with a change in the latter [the conditions of human knowledge].... If this is true, ... we could perhaps expect the imminent dissolution of our topic. [After all, inasmuch as] the foundations of modern knowledge today appear as shaky as political reality itself, ... we should not expect sovereignty to remain unaffected in its ability to organize modern political reality into the two distinct spheres of the domestic and the international.

Bartelson's view of sovereignty-hardly a complimentary one-

53. Id. at 246-47 (first, third, and fourth emphasis added).

54. Id. at 247 . 
characterizes it as rather ill-founded, confused, largely accidental, and possibly on its way toward irrelevance. Other observers, though, hold quite different views.

\section{IB2. Stankiewicz and His Defense of Sovereignty}

About a half-century ago, W. J. Stankiewicz of the University of British Columbia edited a series of symposium papers on sovereignty. Appearing under the overall title of In Defense of Sovereignty, this set of essays examines from various perspectives what sovereignty is and whether it is still worth discussing. In his own introductory essay, Stankiewicz offers critiques of all the other papers appearing in the book, and he sets the tone for those critiques by asserting that "sovereignty is not simply a myth, but a fact of political life which is inconveniently at odds with democratic assumptions of what ought to be." ${ }^{, 55}$ He continues in this vein:

Despite the claims made by the opponents of the concept, the presentday exercise of sovereignty is not far from what the classical theory postulated: the sovereign tends to be an unlimited, supreme, coercive power which has a will and expresses itself through legislation. What has happened is that the loss of support for values in general has once again made order the central value, as it was for Bodin and Hobbes [in first developing the concept of sovereignty]. ${ }^{56}$

The emphasis that Stankiewicz places in that passage on order repeats throughout his analysis. He claims, for instance, that "[i]n essence, sovereignty is a declaration that if order is to have certain characteristics, then an ordering body or sovereign having certain qualities must exist." 57 In another passage, he acknowledges that "one of the more objectionable attributes of the classical concept" of sovereignty is that "sovereignty must be unlimited": this would seem, he says, "to place the sovereign beyond

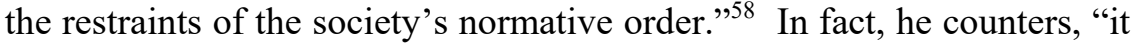
does not do so, since the function of keeping order includes the maintenance of norms which are part of the social order." 59

Stankiewicz defends sovereignty against a number of its detractors. Indeed, he offers sometimes biting criticisms of the essays submitted by

\footnotetext{
55. W. J. StANKIEWICZ, In DEFENSE OF SOVEREIGNTY 3 (1969).

56. Id. at 3-4 (emphasis added).

57. Id. at 5 .

58. Id. at 7 .

59. Id.
} 
his fellow symposium participants. His first target is an essay by Jacques Maritain of Princeton - an essay that concludes with this assertion: "[t]he two concepts of Sovereignty and Absolutism have been forged together on the same anvil. They must be scrapped together." ${ }^{\prime \prime}$ Granted, Maritain offers a large and juicy target for Stankieicz or anyone else wishing to defend the concept of sovereignty. Maritain starts his essay insistently:

It is my contention that political philosophy must get rid of the word, as well as the concept, of Sovereignty: - not because it is an antiquated concept ... and not only because the concept of Sovereignty creates insuperable difficulties and theoretical entanglements in the field of international law; but because, considered in its genuine meaning ... this concept is intrinsically wrong and bound to mislead us if we keep on using it. ${ }^{61}$

In building to this contention, Maritain reports that "Jean Bodin is rightly considered the father of the modern theory of Sovereignty" ${ }^{2}$ - a point that, as mentioned above, ${ }^{63}$ Bartelson might challenge (by insisting that the modern theory of sovereignty is dramatically different from Bodin's views). ${ }^{64}$ According to Maritain, Bodin's view of sovereignty necessarily requires absolutism - both absolutism in the surrender of power by the people in a society and absolutism in the separation and superiority of the person (the sovereign) to whom such power has been surrendered:

Bodin's position is perfectly clear. Since the people have absolutely deprived and divested themselves of their total power in order to transfer it to the Sovereign, and invest him with it, then the Sovereign is no longer a part of the people and the body politic: he is "divided from the people," he has been made into a whole, a separate and transcendent whole, which is his sovereign living Person, and by which the other whole, the immanent whole or the body politic, is ruled from above. When Jean Bodin says that the sovereign Prince is the image of God, this phrase must be understood in its full force, and means that the Sovereignsubmitted to God, but accountable only to Him - transcends the political whole just as God transcends the cosmos. Either Sovereignty means nothing, or it means supreme power separate and transcendent - not at the peak but above the peak ("par dessus tous les subjects") - and ruling the entire body politic from above. That is why this power is absolute

\footnotetext{
60. Jacques Maritain, The Concept of Sovereignty, in IN DEFENSE OF SOVEREIGNTY, supra note 55 , at 64 .

61. Id. at $42-43$.

62. Id. at 43 .

63. See supra note 49 and accompanying text.

64. See, e.g., supra note 49 and accompanying text.
} 
(ab-solute, that is non-bound, separate), and consequently unlimited, in its extension as well as in its duration, and not accountable to anything on earth. ${ }^{65}$

According to Maritain, Hobbes took fundamentally the same position that Bodin did about the absolute power of the sovereign. ${ }^{66}$ That is, the version of sovereignty Hobbes espoused in Leviathan, his master-work of the mid-seventeenth century, also viewed the sovereign as a "Mortal God." $" 67$

Let us re-read at this point Hobbes' unforgettable page: “... The only way to erect ... a Common Power [among men in order] to defend them from the invasion of Forraigners and the injuries of one another ... is, to conferre all their power and strength upon one Man, or upon one Assembly of men, that may reduce all their Wills, by plurality of voices, unto one Will: which is as much to say, to appoint one Man, or Assembly of men, to beare their Person... [This is in essence] a real Unitie of them all, in one and the same Person ... as if every man should say to every man, 'I Authorize and give up my Right of Governing my selfe, to this Man, or to this Assembly of men, on this condition, that thou give up thy Right to him ... in like manner.' This done, the Multitude so united in one Person, is called a Common-Wealth, in Latin Civitas. This is the Generation of the great LEVIATHAN, or rather (to speak more reverently) of that MORTALL GOD, to which we owe under the Immortall God, our peace and defence. [Moreover,] by this Authoritie, given him by every particular man in the Common-Wealth, he hath the use of so much Power and Strength conferred on him, that by terror thereof, he is inabled to forme the wills of them all.... And he that carryeth this Person, is called SOVERAIGNE, and said to have SOVERAIGNE POWER; and every one besides, his SUBJECT." 68

Then comes, for Maritain, the great but perhaps inevitable errorattributable to Rousseau. Note that for both Bodin and Hobbes, the sovereign was always to be separate from the people and subject to the ultimate authority of a Christian God; ${ }^{69}$ this is explicit in Bodin's assertion (quoted above by Maritain) that the sovereign "submitted to God"70 and was "accountable only to Him," (quoted immediately above) that the Leviathan acted "under the Immortall

65. Maritain, supra note 60 , at 47.

66. Id. at 51 .

67. Id. at 52 .

68. Id. at 51-52 (quoting Thomas HobBes, Leviathan, part II, chap. xvii (R. A. Waller ed., Cambridge Univ. Press, 1904) (1651)).

69. Id. See also id. at 47 .

70. Id. at 47.

71. Id. 
God." ${ }^{, 72}$ Maritain castigates Rousseau for distorting those earlier views in introducing as part of his Contrat Social the notion of Votonté Générale ("general will") — what Maritain calls a mythical "superior and indivisible Will emanating from the people as one single unit" sovereignty rested in "the people" 74 through the operation of that "General Will." 75 Maritain says this is logically impossible. ${ }^{76} \mathrm{He}$ calls it "a nonsensical notion"77 that the sort of separateness that both Bodin and Hobbes insisted on in their versions of sovereignty could exist in such a popular sovereignty as Rousseau posited: "it would be simply nonsensical to conceive of the people as governing themselves separately from themselves and from above themselves." 78 Moreover, by removing God from the hierarchy in which sovereignty operated, "Rousseau . . . injected in nascent modern democracies [of his day] a notion of Sovereignty which was destructive of democracy, and pointed toward the totalitarian State."79

In short, Maritain says, Rousseau failed to discard "the separate and transcendent power of the absolute kings" ${ }^{\prime \prime}$ - who at least operated under God and could be challenged in their authority for transgressing against God's higher laws. Instead, Maritain complains, Rousseau made the "spurious power" 81 of kings even more absolute:

The Legislator, that superman described in the Contrat Social, offers us a preview of our modern totalitarian dictators [who preside over the operation of totalitarian states. And recall this:]... . Did not Rousseau think moreover, that the State has a right of life and death over the citizen? "When the prince has said to him: it is expedient for the state that you should die, he must die, since it is only on this condition that he has safely lived up to that time." 82

For Maritain, then, the concept of sovereignty has run its course and should be discarded, along with the absolutism that it always had at its core. In this regard, he emphasizes that even as formulated by Bodin, sovereignty was pre-programmed to sink into absolutism - and sink it did:

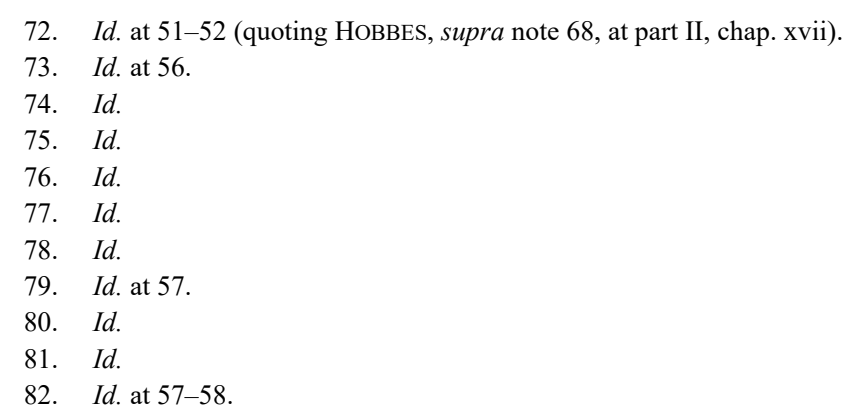


Jean Bodin had indeed submitted the Sovereign to the law of God, but the inner logic of the concept was to make Sovereignty free from everyeven heavenly-limitation. ... In actual fact Sovereignty required that no decision made by the Mortal God, or law established by the General Will, could possibly be resisted by the individual conscience in the name of justice. Law did not need to be just to have force of law. Sovereignty had a right to be obeyed, whatever it might command. Sovereignty was above moral law. The story came to its end once the Sovereignty of the abstract entity of the State had [with the rise of "nation-states"] been substituted for the Sovereignty of the king, and the Sovereignty of the State had been confused [by Rousseau and his followers] with the Sovereignty of the Nation and the Sovereignty of the People. ${ }^{83}$

Stankiewicz disagrees. He acknowledges that "Maritain is quite correct in his contention [that] sovereignty and absolutism are synonymous," 84 but then Stankiewicz argues that what Bodin, Hobbes, and Rousseau aimed to achieve was the proper "relation between power, obligation, and social order." 85 The views of those classical theorists, Stankiewicz explains, "can be epitomized in the statement that order demands a power structure with a head (or supreme decision-maker) able to make ultimate decisions." ${ }^{\text {"86 }}$ Again, therefore, Stankiewicz emphasizes the role of order. "What cannot be ignored is the function of sovereignty in maintaining social order: it is this function which creates the obedience that makes sovereign power and its exercise possible." ${ }^{87}$ Although he does not say so explicitly, we are left to assume that Stankiewicz would acknowledge that the sovereign's failure to fulfill that function of sovereignty would justify disobedience on the part of the subject-citizen.

Stankiewicz, then, seems to think he can have his cake and eat it too. For him, sovereignty is absolute until it stops being absolute due to a serious incompatibility between (i) the sovereign's exercise of power and (ii) "the value-order that the sovereignty must hold [and reflect in his behavior in order] to fulfill his function as a sovereign." $" 88$ I find it curious that Stankiewicz finds this line of reasoning persuasive- that is, that Stankiewicz can call sovereignty and absolutism "synonymous" 89 and yet suggest that the absolutism is somehow conditional. ${ }^{90}$

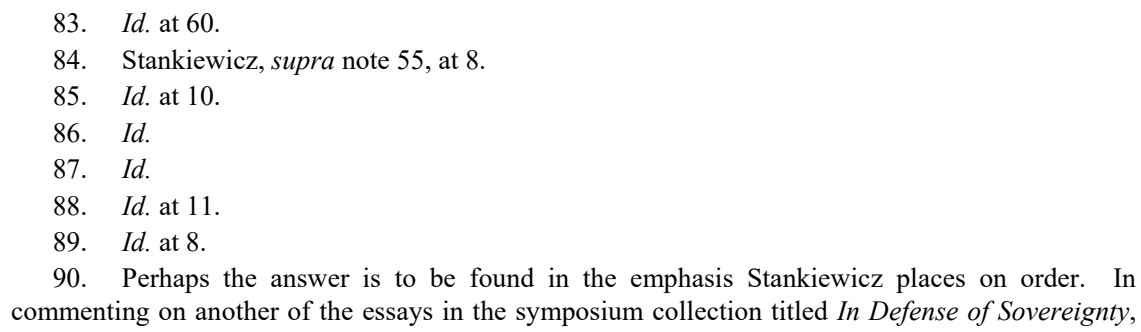


Another of the essays appearing in the volume titled In Defense of Sovereignty reaches similar conclusions to those of Maritain's essay. Stanley Benn of the Australian National University identifies six ways in which the word "sovereignty" might be meaningfully used:

(a) to express the supremacy of a norm in a legal hierarchy, as viewed by a lawyer, or by a student concerned with the legal limits of discretion [what Benn calls "legal sovereignty"];

(b) in a study of constitutions as normative orders, to refer either to the omnicompetence, or to the supreme competence within its field, of a legislative organ [what Benn calls "legislative sovereignty"];

(c) to express the self-sufficiency of a legal order from the point of view of a lawyer operating within it;

(d) to refer to a particular kind of legal order, the definition of which may vary from one legal order to another (its utility in this sense being limited to particular jurisprudence);

(e) to express the ability of bodies such as armed forces to defeat all probable rivals [what Benn calls "sovereignty as 'supreme coercive power"'];

(f) to express the ability of a sectional interest decisively to influence policy [what Benn calls "sovereignty as "the strongest political influence"'] $]^{91}$

One of Benn's main objectives in examining these various meanings is "to determine whether they possess any common element that would justify the use of the one word 'sovereignty' to cover them all." $92 \mathrm{He}$ concludes that they do not:

The first four senses are relevant to normative studies and cannot be directly utilized in historical or sociological studies without confusion. Each of them is a useful concept in its own field, but they seem to have little in common. The first two share the idea of "supremacy" but in slightly different senses of that word; the third is an expression of totality, rather than supremacy; the fourth implies neither notion. The fifth and sixth senses, unlike the first four, do simply ability to determine other people's conduct; and it is in these senses alone that sovereignty implies supreme power. These two senses... can be seriously

Stankiewicz explains Jean Bodin's views on the importance of the sovereign in maintaining order in society. "Bodin ... declares that it is the maintenance of order that creates the sense of obligation [on the part of the people to obey the sovereign], and not, as some critics of sovereignty have supposed, the sovereign's command." Id. at 15.

91. Stanley I. Benn, The Uses of "Sovereignty," in In Defense of Sovereignty, supra note 55 , at $79,82,84-85$.

92. Id. at 69 . 
misleading.

In the light of this analysis it would appear to be a mistake to treat "sovereignty" as denoting a genus of which the [various] species can be distinguished by suitable adjectives, and there would seem to be a strong case for giving up so Protean a word. ${ }^{93}$

The "protean" $" 94$ nature of sovereignty as a concept and as a word is highlighted also by Kenneth Cole, of the University of Washington, in another of the essays appearing in the volume titled In Defense of Sovereignty. Cole opens his essay by observing that "[even the] casual student of Western political history encounters sovereignty in a number of guises," 95 so that in the age "of absolute monarchy, it [sovereignty] was a personal endowment of princes" $"$ and its character changed when democratic regimes arose. ${ }^{97}$ Various political and historical contexts for sovereignty, writes Cole, therefore reveal "the protean possibilities of the general conception" of sovereignty. ${ }^{98}$ In other words, sovereignty has proven to be remarkably malleable over time.

What Cole considers most surprising, though, is that in modern times - dominated by "nation-states" " - the notion of sovereignty has become so very powerful:

The initial idolization of the state was to some extent forced ... by the pressure of historical events .... [particularly] the critical events of the sixteenth century [that required] ... shifting to a particularist system of maintaining order. During the Middle Ages, there had been an attempt to establish a universal order under the aegis of the Christian faith and upon the foundation of a common European tradition reaching back to the twin classical models of Greece and Rome. [Although] [t]his order had never worked to insure [adequate levels of peace,] ... . the schism within the religious community [made it] ... evident that the old order was doomed. The only alternative was to accept the dismembered parts as self-sufficient units within which to rehabilitate strong government.

The principle of sovereignty was the great ideological weapon used by the nation-states in accomplishing [this rehabilitation].... There is a sense, therefore, in which sovereignty may be said to have provided a shelter necessary for the preservation of Western civilization after the religious wars. On the other hand, however, we must emphasize that the

93. Id. at 85 .

94. Kenneth C. Cole, The Theory of the State as a Sovereign Juristic Person, in IN DEFENSE OF SOVEREIGNTY, supra note 55, at 86.

95. Id.

96. Id.

97. Id.

98. Id.

99. Id. at 88 . 
kind of "sovereignty" called for on this account does not by any means measure up to the pretensions of the sovereignty which actually came to be claimed by the nation-states [over the succeeding centuries]. What each sovereign could reasonably claim as a prerequisite for effective local government was a finality of decision on all issues arising within his realm. This was because the responsibility for maintaining order could not be discharged without insulating the system of law enforcement within the state from all outside control. Hence the device of forbidding appeals from national courts to any foreign or international tribunals may be justified on this basis.

But insulation of the nation-state in the matter of law enforcement is a very different thing from insulation as respects law itself. The maintenance of order on a particularist basis requires that local interpretation of general law be final; it does not require a denial of the existence of a general law. ${ }^{100}$

According to Cole, the expansive (and, in his view, unwarranted) conception of state sovereignty can be traced "to the mistakes of its most prominent opponents,"101 including what he describes as "right-wing" ultra-conservatives, ${ }^{102}$ "left-wing" socialists,${ }^{103}$ and critics taking pluralist, sociological, and juristic approaches. ${ }^{104}$ Cole says that those mistakes, which he refers to also as "the ineptitude of the attack on sovereignty," 105 have left us with a concept of state sovereignty that "ignore[s] traditional conceptions of legality." 106

Stankiewicz denounces both Benn's analysis and Cole's analysis, but in ways that I find unconvincing when considering sovereignty as a legal concept. Stankiewicz acknowledges that Benn has identified six distinct meanings of sovereignty, "each of which has awkward difficulties of interpretation and application," 107 but Stankiewicz's rejection of Benn's conclusion - that these difficulties should prompt us just to discard "sovereignty" as a concept in this context—seems to rest on distinguishing

\footnotetext{
100. Id. at 87-89 (first and third emphasis added).

101. Id. at 90 .

102. Id.

103. Id. at 91 .

104. Id. at 98. Cole gives an extensive analysis of how, from a juristic (legal) perspective, it ultimately proves impossible to identify satisfactorily just where, or in what organ of the state, sovereignty is supposedly located. After proposing and rejecting numerous candidates, he says "the most attractive stop-gap candidate for sovereignty ... is ... the organ originally employed to draft the constitution" (that is, the constitutional convention) - but he explains why, on reflection, it also makes no sense to assign such a role to that organ. $I d$. at 96-102.

105. Id. at 92 .

106. Id. at 90 .

107. Stankiewicz, supra note 55, at 11 .
} 
between a juristic view of law and a political-science view of law. ${ }^{108}$ For Stankiewicz, the latter of these is more important, in part because it is "dynamic," whereas "[t]he juristic view of the law is a static one."109 In like manner, it seems that the critique Stankiewicz directs at Cole's essay also rests on the view that sovereignty should be a concept that serves a wide range of purposes, of which the political-science purposes are overarching in importance. ${ }^{110}$ The last line in Stankiewicz's attempted rebuttal of Cole's essay admits that it is a mystery "why jurists use the concept of sovereignty, despite the appalling difficulties it creates." 111

In my view, this acknowledgement by Stankiewicz that the concept of sovereignty creates "appalling difficulties," 112 and that the meaning of the concept is more troublesome and less clear in the context of a juristic view of law, ${ }^{113}$ can only support (not diminish) the central position that Benn and Cole (and Maritain, for that matter) urge: that at least as a legal concept, sovereignty is deeply flawed because its definition is muddled, its emergence is an accident of history, and its faithfulness to absolutism is objectionable in today's world. ${ }^{114}$

\section{IC. Default-Setting Sovereignty}

In addition to being deeply flawed, it seems that sovereignty is most appropriately regarded as also being partly optional, in the sense that states can opt out of it in certain circumstances. This is a point brought home clearly by two sets of essays. The first, under the title of Problematic Sovereignty, examines, as of about two decades ago, the political-

\footnotetext{
108. Id. at 18 .

109. Id.

110. Id.

111. Id. at 21 .

112. Id.

113. Id. at 18 .

114. Stankiewicz also criticizes an essay by the internationally-renowned Hans Kelsen of Berkeley. Kelsen's essay asserts that "[t]he term 'sovereignty,' while denoting one of the most important concepts in the theory of national and international law, has a variety of meanings, a fact that causes regrettable confusion." Hans Kelsen, Sovereignty and International Law, in IN DEFENSE OF SOVEREIGNTY, supra note 55, at 115. Kelsen offers means of reducing that confusion but explains that doing so requires choosing between two concepts of international law-one that (in simplified form) accepts international law or one that rejects international law as a valid normative order. $I d$. at 118-31. Stankiewicz asserts that Kelsen's discussion of sovereignty "is not easy to reconcile with that of a political scientist"; he surmises that "Kelsen's difficulties [in dealing with some misapplications of the concept of sovereignty] perhaps illustrate why some political scientists have insisted that 'law' is but part of a larger discipline." Stankiewicz, supra note 55, at 23, 27. Again, I find little persuasive value to an argument "in defense of sovereignty" that rests primarily on political-science grounds: such an argument does little to address how sovereignty can be used effectively (if at all) as a legal concept in today's world. Id.
} 
governance arrangements that apply in a cluster of unusual states and regions of the world. ${ }^{115}$ The second set of essays, published very recently, surveys a range of constitutional and structural options that reveal a more creative and sophisticated approach to political-governance arrangements than the traditional views of state sovereignty would offer ${ }^{116} \ldots$ even if a clear definition of sovereignty were available.

\section{IC1. Problematic Sovereignty and Practical Solutions}

In his introductory essay to the 2001 book Problematic Sovereignty, Stephen Krasner enumerates the questions that the volume addresses:

[i] [T]o what extent do existing institutional arrangements, rules, and principles associated with the concept of sovereignty inhibit the solution to some of the most pressing issues in the contemporary international order? [ii] Can these rules be bent? [iii] Can they be ignored? [iv] Do they present an insurmountable or at least significant barrier to stable solutions, or $[\mathrm{v}]$ can alternative arrangements be created? ? $^{17}$

In summarizing the analysis of the various essays that comprise the volume, Krasner offers these answers: (i) yes, existing rules of sovereignty do inhibit the solution of some pressing issues, at least in their vigorous application, but (ii) yes, these rules can be bent and even (iii) ignored in certain circumstances, especially by means of voluntary arrangements reached between concerned parties; as a consequence, (iv) no, the traditional rules of sovereignty do not present an insurmountable barrier to stable solutions - and just how significant a barrier they might present turns on (v) how imaginative and resourceful the involved parties are in creating alternative arrangements. ${ }^{118}$ Or, to use Krasner's own formulation in the preface to the book Problematic Sovereignty, "[ $\mathrm{t}] \mathrm{he}$ fundamental conclusion of this study is that the rules of sovereignty are not absolutely constraining. They are not taken for granted. New rules can be written; conventional ones can be ignored." 119

115. See generally Problematic Sovereignty vii-viii (Stephen D. Krasner, ed., 2001) [hereinafter PROBLEMATIC SOVEREIGNTY]. The essays in that collection focus mainly on Hong Kong, Tibet, Belarus, Taiwan, Bosnia, and Palestine. Id.

116. Regional Autonomy, Cultural Diversity and Differentiated Territorial Government: The Case of Tibet-Chinese and Comparative Perspectives (Jens Woelk \& Roberto Toniatti, eds., 2017) [hereinafter Woelk \& Toniatti]. I contributed two chapters to that collection, focusing on constitutionalism and rule of law in China. Id. at 23-66.

117. Stephen D. Krasner, Problematic Sovereignty, in Problematic SovereignTy, supra note 115 , at 1.

118. See generally discussion infra Sections IC, IE, \& IF.

119. Problematic Sovereignty, supra note 115 , at viii. 
Let me briefly "unpack" that set of conclusory statements by expanding slightly on some key points Krasner and his contributing authors make. A first such point is definitional in character: as Krasner explains, "[t]he concept of sovereignty has been used by sociologists, international lawyers, and political scientists, but not always with the same meaning." 120 For international lawyers, he says, "individual states are the basic building blocks of the international system. These states are sovereign in the sense that they are juridically independent and can enter into treaties that will promote their interests as they themselves define them." 121

Second, Krasner then identifies "four aspects, or different ways of conceptualizing or talking about sovereignty,"122 as follows:

[i] Interdependence sovereignty refers to the ability of a government to regulate the movement of goods, capital, people, and ideas across its borders. [ii] Domestic sovereignty refers both to the structure of authority within a state and to the state's effectiveness or control. [iii] International legal sovereignty refers to whether a state is recognized by other states, the basic rule being that only juridically independent territorial entities are accorded recognition. [iv] Westphalian sovereignty, which actually has almost nothing to do with the Peace of Westphalia, refers to the autonomy of domestic authority structuresthat is, the absence of authoritative external influences. ${ }^{123}$

Third, Krasner emphasizes that these four aspects of sovereignty "do not necessarily go together," 124 and that the essays in the book he has edited have been chosen precisely because they show how malleable and non-necessary some of these aspects of sovereignty really are in actual practice. ${ }^{125}$ Specifically, he explains that "[i]n Taiwan, Hong Kong, Tibet, Bosnia, Palestine, and Belarus the rules associated with one or more of the

\footnotetext{
120. Krasner, supra note 117 , at 1.

121. Id.

122. Id. at 2. Krasner elaborates on all four of these aspects. Id. at 7-12.

123. Id. at 2 (emphasis added). In elaborating briefly on the last of these points, Krasner comments that "[a] state might claim to be the only legitimate enforcer of rules within its own territory, but the rules it enforces might not be of its own making." Id. This echoes a point made by Benn, as quoted above: "insulation of the nation-state in the matter of law enforcement is a very different thing from insulation as respects law itself. The maintenance of order on a particular basis requires that local interpretation of general law be final; it does not require a denial of the existence of a general law." See supra note 100 and accompanying text.

124. Id. In this respect, Krasner explains that gaining international recognition for a state "has sometimes involved sacrificing Westphalian sovereignty" and "[m]embership in international organizations has required relinquishing control over transborder movements." Krasner, supra note 117 , at 2 .

125. See generally discussion infra Sections IC, IE, \& IF.
} 
[four above-mentioned] characteristics associated with sovereignty have not been, or could not have been, followed."126 In short, sovereignty is "problematic" (hence the title of the book) in each of those settings.

Fourth, Krasner then summarizes how, in nearly all of those settings (Taiwan, Hong Kong, etc.), some "institutional arrangements that are inconsistent with conventional rules of sovereignty have been embraced."127 Post-1997 Hong Kong, for instance, lacks "domestic sovereignty" as defined earlier, ${ }^{128}$ since it does not have formal juridical independence, and yet "it enjoys international legal sovereignty" to some degree. ${ }^{129}$ Similarly, "Belarus hardly seems to have made a serious effort to establish its domestic and Westphalian sovereignty, and its leader [then it was Alyaksandr Lukashenka] has toyed with the idea of relinquishing his state's international legal sovereignty as well," especially by "press[ing] the Russian government to conclude one agreement after another to accelerate the integration, or reintegration, of the two countries' economies and to forge the closest possible political ties." ${ }^{130}$ Likewise, the situation in Taiwan "also confounds convention notions of sovereignty," inasmuch as "Taiwan has prospered in a kind of never-never land where it has many of the attributes of fully sovereign statesterritory, population, and domestic and Westphalian sovereignty-but only very limited international legal sovereignty."131

Fifth, Krasner highlights the fact that Tibet appears to be a case in which "the rules associated with sovereignty appear to have powerfully constrained the options that are available to actors," as is evident in the fact that neither Tibet's leaders "nor the leaders of China appear willing to embrace a status that would be something in between complete independence on the one hand and the status quo on the other." 132 This special case of Tibet is one that I will return to in Section IC2, immediately following this one.

Lastly, in offering some concluding remarks, Krasner portrays the traditional approach to state sovereignty as relying on a "bundled" concept, under which all four of the aspects of sovereignty-

\footnotetext{
126. Krasner, supra note 117 , at 2.

127. Id. at 4 .

128. See supra note 123 and accompanying text.

129. Krasner, supra note 117 , at 4.

130. Id. at 16. Krasner continues by explaining that Lukashenka "seems intent on ignoring, even to the extent of violating[,] some of the basic rules of international legal sovereignty by displacing foreign ambassadors from their residences." $I d$. at 16.

131. Id. at 17. For a discussion of these four attributes of sovereign states, see infra note 386 and accompanying text.

132. Krasner, supra note 117 , at 3.
} 
interdependence sovereignty, domestic sovereignty, international legal sovereignty, and Westphalian sovereignty, to use his terms - are assumed to be necessary elements to consider a state "really" sovereign. According to Krasner, this "bundled" approach is wrong: "By so readily accepting the bundled nature of sovereignty, students of international politics have constrained the range of issues they have addressed." 133 They should instead try to understand "the conditions under which alternatives to conventional notions of sovereignty are viable."134 Doing so for the cases summarized in the book he has edited shows that as a practical matter, "sovereignty in its fully bundled form [sometimes] does not provide an optimal outcome. In some instances, including Hong Kong and Taiwan, decision makers have found a plausible alternative. In others, such as Tibet, they have not." "135 In those instances, the "bundled" approach to sovereignty is "the default." ${ }^{136}$ Krasner cautions, however, that whatever innovative institutional arrangements are constructed are most likely to work "if they are the result of voluntary agreements that establish equilibrium outcomes."137

The work of Krasner and his contributing authors strongly suggests that two ingredients are most important in dealing with the concept of sovereignty in the setting that, as I explained at the outset of this Article, stand at the centerpiece of my current research - that is, global institutional measures to facilitate a transition to a new natural-systems form of agriculture. Those two ingredients are imagination and negotiation. Imagination is needed to design ways in which a range of affected entities - existing states, nongovernment organizations, international institutions, farmers, and others - can participate in the formulation and implementation of ecologically responsible rules governing agricultural production and ecological protection. Negotiation will be needed in order to move from design to agreement, bearing in mind Krasner's cautionary note that alternatives to what he calls the traditional "bundled" approach to sovereignty are most likely to work if they result from voluntary cooperation.

IC2. Options for Tibet and Other Specific Instances

Before studying these two ingredients - imagination and

133. Id. at 20 .

134. Id.

135. Id.

136. Id.

137. Id. at 21 . 
negotiation-more closely, let us see how another quite recent set of observations on sovereignty might provide further guidance. Recall that Krasner identified Tibet as a case in which traditional sovereignty rules served as powerful constraints on the options available to Tibet and the People's Republic of China in constructing a status between those two entities that is satisfactory to them both. ${ }^{138}$ A 2017 volume of essays attempts to whittle away at those constraints by surveying a variety of administrative and governance arrangements that have been put in place around the world to address special needs and circumstances of distinct populations within states.

As explained by Jens Woelk, one of the editors of the 2017 Tibetrelated book, the Memorandum on Genuine Autonomy for the Tibetan People (2008), is a proposal issued by the Tibetan Government in Exile in hopes of identifying a mechanism by which "the specific needs of the Tibet nationality for autonomy and self-government can be met through application of the principles on autonomy of the Constitution of the People's Republic of China." 139 Woelk continues:

The Memorandum is a Tibetan projection of the instrument of autonomy into the Chinese constitutional and legal framework.... The Memorandum uses the frame of the Chinese system and in particular two of its pillars: the differentiated and asymmetrical system of territorial governance and the elaborated system of minority-protection. ${ }^{140}$

Those two "pillars" of the Chinese system can, Woelk argues, provide adequate constitutional grounds for providing autonomy to Tibet-not independence, not secession, not “external sovereignty," but autonomy. ${ }^{141}$ He then explains that although a "right to autonomy is not (yet) recognised in international law," 142 there are in fact "numerous autonomy arrangements around the world." "143 He also explains that "[t]erritorial autonomy enables a group [of people] to form a de facto majority within

\footnotetext{
138. See discussion infra Section IC1.

139. Jens Woelk, Neither Panacea, nor Pandora's Box: Comparing Autonomy with a View on Tibet and China, in Woelk \& Toniatti, supra note 116, at 12 (citing the "Memorandum" itself).

140. Id. at 14 .

141. Id.

142. Id. at 2. For discussions of the movement toward a right to autonomy in international law, Woelk cites Beyond a OnE-Dimensional State: An EMERGing Right to AutonOMY? (Zelim Skurbaty ed., 2005) and Steven C. Roach, Minority Rights and an Emergent International Right to Autonomy: A Historical and Normative Assessment, 11 InT'L J. ON MinORITY \& GROUP RTS. 411 (2004). Woelk also acknowledges that "[t]he term autonomy is used differently by [various] scholars" and directs readers to Michael Tkacik, The Characteristics of Forms of Autonomy, 15 INT'L J. ON MINORITY \& GROUP RTS 369 (2008).
}

143. Woelk, supra note 139 , at 3. 
(a part of) the State, [and] thereby exercise[] ... [a significant] degree of control on government in this territory." 144

Much of that book proceeds to "draw on the experiences of other autonomous areas around the world" 145 in order to explore whether, and how, some such experiences might provide inspiration for a political and constitutional arrangement between Tibet and China. My interest here, of course, is not with Tibet, nor is it with the concept of autonomy per se. After all, those matters concentrate mainly on minority rights of human populations. Still, the various illustrations examined in that Tibet-related book demonstrate that sovereignty is more complicated, and can be made more nuanced and circumstance-specific, than is commonly assumed.

The particular instances of autonomy the various contributors to that Tibet-related book explain come from Italy (Südtyrol), ${ }^{146}$ Canada, ${ }^{147}$ Indonesia, ${ }^{148}$ India ${ }^{149}$ Malaysia ${ }^{150}$ and elsewhere. ${ }^{151}$ In each of those cases, special constitutional arrangements have been designed and implemented (or, in Indonesia, are in the process of implementation) to enable the members of a minority population to live in a manner that is consistent with their own character and circumstances, thereby preserving their identity and the cultural diversity that they contribute to the larger

144. Id.

145. Id. at 2 .

146. Jens Woelk, From Compromise to Compact: Working autonomy in South Tyrol, in Woelk \& Toniatti, supra note 116, at 133 (focusing on the South Tyrolean autonomy arrangement dating back several decades).

147. Jean-François Gaudreault-Desbiens, Can Quebec's Relative Autonomy within Canada be a Template for Tibet?, in Woelk \& Toniatti, supra note 116, at 194 (focusing on the autonomous powers and the relative cultural autonomy that Quebec enjoys within the Canadian federation).

148. Hans-Joachim Heintze, The Autonomy of Aceh, in Woelk \& Toniatti, supra note 116, at 225 (focusing on the special arrangements that are envisioned, but not yet fully implemented, to provide autonomous powers of Aceh within Indonesia).

149. Thomas Benedikter, Territorial Autonomy in India, in Woelk \& Toniatti, supra note 116, at 253 (focusing on the special asymmetrical federal arrangements that are enshrined in India's constitution).

150. Andrew Harding, Is Malaysian Federalism a Good Example or a Warning for Solving the China/Tibet Issue? A brief inquiry into a half-century experiment in asymmetric federalism, in Woelk $\&$ Toniatti, supra note 116, at 267 (focusing on the special arrangements for the states of Sabah and Sarawak).

151. One of the editors also explains that in several other instances, attempts to put similar arrangements in place have failed largely because autonomy rights "are often (wrongly) associated with the idea of secession." Woelk, supra note 139, at 4. This is also, he says, "the primary reason for the reluctance of States to recognize such a right [of autonomy] at [the] international level." Id. In that regard, however, he notes that "some recent international documents and instruments show that the International Community is at least considering self-government options"- and he cites in this respect the UN Declaration of the Rights of Indigenous Peoples, Article 35 of the Copenhagen Declaration on Human Dimension of the Conference on Security and Cooperation in Europe, and the so-called "Lund Recommendations" on Effective Political Participation in Public Life of National Minorities. Id. 
society - and from which the larger society benefits. ${ }^{152}$

In sum, the 2017 Tibet-related book provides specific, solid examples of how the traditional doctrine of state sovereignty, which the editors acknowledge to be "a European invention," "153 has been modified to fit particular circumstances calling for more effective governance. This series of actual examples supports the assertion made by Bartelson, Maritain, and others (as described above in Section IB) that sovereignty is sloppy, malleable, and subject to distortion and departure.

\section{ID. Macho Sovereignty?}

Much of the foregoing discussion is highly technical, parsing a wide variety of detailed definitions and analyses of sovereignty-and, in the immediately preceding paragraphs, of "autonomy." I suggest now a change of pace, in order to reflect on the fact that sovereignty - at least in some general form, however sloppy-is a concept that has extremely broad and deep resonance in the public at large. Whatever finely-reasoned intellectual treatment we might wish to give to the concept and to how it might best be interpreted or modified, we must recognize that this is a legal and political concept that gets bandied about widely in the popular press and in political rhetoric.

I start with some illustrations, and then I offer some observations about what relevance these "regular-person" perspectives on sovereignty might have for purposes of dealing with sovereignty in the context of global institutions and transitioning to a new natural-systems form of agriculture.

- Late in his campaign for the U.S. presidency, Donald Trump used the term "sovereign" vaguely, perhaps as a synonym for "independent" or "autonomous": "We've seen this firsthand in the WikiLeaks documents in which Hillary Clinton meets in secret with international banks to plot the destruction of U.S. sovereignty in order to enrich these global financial powers, her special interest friends and her donors."154

- Earlier in his campaign, Trump used the term to signify

152. See supra notes $122-27$ and accompanying text.

153. Woelk, supra note 139, at 7. Woelk goes on to emphasize the artificiality of the doctrine of the nation-state: "In fact, the (presumed) homogeneity of the populations forming a Nation making up a State has, in most cases, rather been a mirage," especially as "[f]requent border changes and exchange of territories made it necessary to integrate groups with different characteristics compared to the majority population of the State." Id.

154. See Niraj Chokshi, Trump Accuses Clinton of Guiding Global Elite Against U.S. Working Class, N.Y. TimES (Oct. 13, 2016), http://www.nytimes.com/2016/10/14/us/politics/trumpcomments-linked-to-antisemitism.html?_r=1 [https://perma.cc/C87D-8B9S]. 
territorial exclusivity: "Immigration ... should mean improvements to our laws and policies to make life better for American citizens .... It is our right as a sovereign nation to choose immigrants that we think are the likeliest to thrive and flourish here." 155

- Theresa May, in referring to the UK's exit from the EU, used "sovereign" in the sense of "unaffiliated" with an external political structure: "We are going to be a fully independent, sovereign country - a country that is no longer part of a political union with supranational institutions that can override national parliaments and courts."156

- In his blog The Patriot Post, self-described patriot Arnold Ahlert links "sovereignty" to national character: "This is a fight between those who believe in the exceptionalism of our nation and the sovereignty that engenders it, and those who view America as just another "market" like any other, one to be ruled by a cabal of transnational elitists with utter contempt for that exceptionalism, our workers and our Constitution."157

- The political commentator Glenn Beck distinguished sovereignty from "internationalism": "Global politicians and global corporations are playing games; they'll get rich by building a box for American entrepreneurs to live in. They may think they can end American sovereignty and start internationalism, but they haven't met the Americans I have, who on tax day will kick out of the box they refuse to be placed in."158

- Jeff Sessions, before becoming U.S. Attorney General, linked sovereignty with border security: "If you don't secure the border, as Trump said, you don't have a nation. Your sovereignty is undermined."159

155. Trump: It is Our Right as a Sovereign Nation to Choose Immigrants Likely to Thrive, REAL CLEAR POLS. (Aug. 31, 2016), https://www.realclearpolitics.com/video/2016/08/31/trump_it_is_our_ right_as_a_sovereign_nation_to_choose_immigrants_likely_to_thrive.html [https://perma.cc/PS86F84Z].

156. Theresa May's Conservative Conference Speech: Key quotes, BBC News (Oct. 2, 2016), http://www.bbc.com/news/uk-politics-37535527 [https://perma.cc/54EB-QPXV].

157. Arnold Ahlert, The TPP Will Destroy America's National Sovereignty, PATRIOT POST (June 9, 2015), https://patriotpost.us/opinion/35665 [https://perma.cc/LG5E-KRGF].

158. Glenn Beck, For Sale: American Sovereignty, Fox News (Apr. 2, 2009), http://www.foxnews.com/story/2009/04/02/for-sale-american-sovereignty.html [https://perma.cc/9D S6-2349].

159. John Hayward, Jeff Sessions: America's Sovereignty at Stake in 2016 Presidential Election, BREITBART NEws (Mar. 24, 2016), http://www.breitbart.com/2016-presidential-race/2016/03/24/jeff- 
- In the same vein, a Tennessee congresswoman also linked sovereignty to national-border and immigration control: "I think that one of the things we have talked about regularly is making certain we know who enters and who exits and that they're coming on the appropriate visa.... We need to protect the sovereignty of our nation and we need to protect the security of our people here in the country." 160

- Another commentator associates sovereignty with energy independence: "What sacrifices American sovereignty is when our nation is beholden to unstable nations for our energy rather than aligning with allies and developing our own natural resources." 161

- Russian President Vladimir Putin links sovereignty with national pride and singularity: "If for many European countries, sovereignty and national pride are forgotten concepts and a luxury, then for the Russian Federation a true sovereignty is an absolutely necessary condition of its existence," Putin is reported as having told a full room of cabinet ministers, lawmakers, and community leaders. "I want to stress: either we will be sovereign, or we will dissolve in the world. And, of course, other nations must understand this as well." $" 162$

These various uses of the term "sovereign" and "sovereignty" are rather fuzzy in their intended meanings, but their context suggests that they aim to convey a sense of national strength, autonomy, and freedom from institutions and influences that are "foreign" to the state whose sovereignty is being emphasized. Their content suggests further a sense of muscularity, perhaps a "machismo," to the image that the terms are intended to convey.

sessions-americas-sovereignty-at-stake-in-2016-presidential-election/ [https://perma.cc/Y9S5DHAQ].

160. Matthew Boyle, Marsha Blackburn on Chattanooga: 'We need to protect the sovereignty of our nation', BREITBART NEWS (July 16, 2015), http://www.breitbart.com/big-government/ 2015/07/16/exclusive-marsha-blackburn-on-chattanooga-we-need-to-protect-the-sovereignty-of-ournation/ [https://perma.cc/VW28-3RFT].

161. Whitney Pitcher, Carney: Keystone Pipeline would 'sacrifice American sovereignty', BREITBART News (Apr. 23, 2012) (quoting a White House press secretary under President Barack Obama, commenting on the proposed Keystone Pipeline), http://www.breitbart.com/biggovernment/2012/04/23/jay-carney-keystone-pipeline-would-preemptively-sacrifice-americansovereignty/ [https://perma.cc/FLT4-4YYL].

162. Putin Defends Aggressive Foreign Policy as Necessary for Russia's Survival: 'We will be sovereign, or dissolve', NAT'L POST (Dec. 4, 2014), http://news.nationalpost.com/news/putindefends-aggressive-foreign-policy-as-necessary-for-russias-survival-we-will-be-sovereign-ordissolve [https://perma.cc/B6GX-2LLT]. 
To some extent, these usages of "sovereign" and "sovereignty" also seem to involve the sentiments of nationalism, strength, and solidarityand especially a sense of separateness from others (other people, other states, other entities). The significance of these populist and non-specific connotations of "sovereign" and "sovereignty" is this: so long as these terms are used in vague ways to reflect and celebrate pride in a country's strength, independence, autonomy, and separateness, efforts at establishing and nurturing cooperative arrangements aimed at collective solutions to global problems (with causes and consequences crossing state boundaries) will be hampered by invocation of "sovereignty" as an immutable value. Like the queen in chess, "sovereignty" can move in any direction and take out any competing piece or proposal, without much opportunity for rebuttal.

\section{IE. Sovereignty and States from a Practitioner's Perspective}

In the course of my exploration of sovereignty thus far in this Article, I have drawn from a variety of sources, ranging from highly technical analyses to broad popular rhetoric and ramblings. Now I concentrate on another source: international practitioners whose views on sovereignty bear on "how the rubber hits the road" in actual legal and diplomatic affairs at the global level. For this, I draw mostly from the observations of two such practitioners, as supplemented by my own experience in working extensively in over a dozen countries and in three international organizations.

In recounting earlier a number of criticisms that have been directed against the concept of sovereignty, I offered this summary: at least as a legal concept, sovereignty has been found by many commentators to be deeply flawed because its definition is muddled, its emergence is an accident of history, and its faithfulness to absolutism is objectionable in today's world. ${ }^{163}$ As part of the book Problematic Sovereignty that I have referred to above, ${ }^{164}$ Thomas Heller and Abraham Sofaer-two highly renowned international legal practitioners ${ }^{165}$ - co-authored an essay

\footnotetext{
163. See supra note 110 and accompanying text.

164. See supra note 115 and accompanying text.

165. Thomas Heller is a climate policy lawyer currently serving as chairman of the board of Climate Policy Initiative. His career has concentrated on law, economic development, and the performance of legal institutions, especially those in the developing world. He was a contributing lead author for various reports of the Intergovernmental Panel on Climate Change and has served on the faculties of the University of Wisconsin and Stanford University. Abraham Sofaer served as a U.S. Supreme Court clerk, as an assistant U.S. attorney, as a federal district judge in New York, as Legal Advisor to the U.S. Department of State, in private practice in Washington, D.C., and as a senior
} 
offering a "practitioners' perspective" on sovereignty. ${ }^{166}$ In doing so, they acknowledged "the confusion, controversy,... and scorn that surrounds ... the concept of sovereignty," and in fact they note that the editor of the Problematic Sovereignty volume, Stephen Krasner, has "conclude[d] that the concept of sovereignty is "mired in hopeless confusion." "167

Still, Heller and Sofaer offer several reasons why the concept of sovereignty is "used so extensively and casually in international diplomacy and legal practice." ${ }^{168}$ All of those reasons concentrate on the importance of states. Heller and Sofaer insist, for instance, that "sovereignty signals a status that has many specific, functional purposes in international diplomatic and legal practice, and to that extent it has concrete and useful meaning... [regarding the central] powers and obligations that attend the status of statehood."169 "States dominate the transnational arena," they explain, ${ }^{170}$ and the notion of sovereignty serves as an exceptionally useful shorthand for summarizing the cluster of rights and powers that states possess.

The enumeration of such rights and powers offered by Heller and Sofaer is one of the better ones I have seen. They explain that " $[\mathrm{t}] \mathrm{o}$ qualify as a state (possessing sovereignty), an entity must have a defined territory and population under the control of its own government, which has the capacity to engage in relations with other states."171 They then note that with statehood "comes certain rights, capacities, and obligations," including: ${ }^{172}$

- The right to its territorial integrity

- The right to use necessary and proportionate force in individual or collective self-defense

- The right to govern its population by prescribing, applying, and enforcing law within its jurisdictional competence

\footnotetext{
fellow at the Hoover Institution at Stanford University. During his tenure at the State Department, he gave special attention to disputes involving Egypt, Israel, Iraq, Chile, and the Iran-Contra scandal. In private practice, he represented the World Wildlife Fund, served as an arbitrator in several international disputes, and advised on affairs related to the PanAm 103 terrorist bombing. Supra note 115 , at xi-xii.

166. Thomas C. Heller \& Abraham D. Sofaer, Sovereignty: The Practitioners' Perspective, in PROBlematic SovereignTY, supra note 115, at 24-52.

167. Id. at 24 .

168. Id.

169. Id.

170. Id. at 25 .

171. Id. at 26. For further discussion of these qualifications of a state and sovereignty, see infra note 386 and accompanying text.

172. Heller \& Sofaer, supra note 166, at 26.
} 
- Eligibility to become a member and fully participate in the United Nations and other international bodies, . . . and to join in litigation in the International Court of Justice (ICJ) as a party

- The capacities of a legal person, such as to own, purchase, or transfer property, to enter into contracts, and to seek and be subject to legal remedies

- Immunities from the application of national law for its noncommercial activities, its diplomats and diplomatic property, and its head of state

- The capacity to join with other states in making international and transnational law through international treaties, agreements, and conduct

- The duty to respect the territorial integrity, political independence, and rights of other sovereignty nations

- The duty to abide by international norms of conduct agreed to by treaty or considered universal and part of customary law. ${ }^{173}$

Importantly, Heller and Sofaer acknowledge that the international community, along with the status of states, must be seen as undergoing a process of change. For one thing, "[s]tates are increasingly surrendering some of their policy options through international agreements and sharing their authority and functions with international institutions and nongovernmental forces," ${ }^{174}$ a trend that Heller and Sofaer say is captured in the notion of "interdependent sovereignty" that Krasner has identified. ${ }^{175}$ However, they insist that legal practitioners understand that these acts by states "do not legally constitute a surrender of sovereign power, but rather its exercise." 176

Beyond this general acknowledgement of change, Heller and Sofaer also make a bigger concession as they look to the future of sovereignty and the role of states:

\footnotetext{
173. Id. at 26-27.

174. Id. at 25 .

175. See supra note 123 and accompanying text.

176. Heller \& Sofaer, supra note 166, at 25 (emphasis added). In a later passage, Heller and Sofaer explain that the Permanent Court of International Justice (PCIJ) examined the interaction between treaty-making and sovereignty in the very first case to come before it. In that case, Germany argued that "a treaty negotiated after the First World War that required Germany to give access to all vessels through an internal waterway could not be valid because it constituted a surrender of sovereignty, in particular the right of a state to maintain its neutrality." Id. at 31-32. The court, in rejecting that argument, acknowledged that a treaty requiring or prohibiting action by a state obviously "places a restriction upon the exercise of the sovereignty rights of the State" but that the proper way to characterize "the right to enter into international engagements is [as] an attribute of State sovereignty," not a violation of it. Id. at 32 (quoting S.S. Wimbledon Case (U.K. v. Ger.), 1923 P.C.I.J. (ser. A) No. 1, at 25 (Aug. 17).
} 
The commitments and delegations [that] nations have made over the last fifty years do, however, represent a process that has changed the roles of states. It may eventually alter their powers. States have delegated to international organizations and private entities the power to administer programs, to adjudicate controversies (especially over trade issues), and to propose policies. Sometimes, these delegations are under standards so vague as to confer significant discretion. Such delegations may be so broad that they conflict with national laws or could become so extensive that sovereignty would be surrendered. ... [In particular, states] that are members of the European Union (EU) have materially limited aspects of their powers to prescribe and apply rules, particularly in commercial and human rights matters but increasingly in matters of national finance and foreign affairs.... In the final analysis, the EU states may choose to merge their sovereignty into a regional entity, as the states of the Confederation chose to do in 1789 [in North America]. That would reduce the number of states in the world but would not alter the fact that sovereign states control the transnational arena. ${ }^{177}$

A point of special interest appears in the last sentence of the passage. Heller and Sofaer assert there that action by EU states "to merge their sovereignty ... would not alter the fact that sovereign states control the transnational arena." $" 178$

Really? In a later paragraph of their paper, Heller and Sofaer acknowledge that some of the rights, capacities, and obligations that they enumerated earlier 179 "are possessed by or may apply to entities other than states." 180 The authors have little choice but to acknowledge this, given the experience of the EU. Heller and Sofaer do discuss the EU, noting that a process is underway there "that can already be characterized as one in which certain aspects of sovereign power are shared or relocated." give several illustrations of this, drawing from various aspects of EU governance-decision processes not requiring unanimous assent, establishment of common policy decisions on foreign affairs and security issues via intergovernmental bodies, and "an increasingly complex mosaic of voting rules and judicial capacities ... [that reach] deep into issues of frontier control [and other issues] long imagined to be at the very core of sovereign territorial control." 182

Given these illustrations from the EU experience, it is no surprise that Heller and Sofaer acknowledge that "[c]hanges in the distribution of

\footnotetext{
177. Id. at $25-26$.

178. Id.

179. See supra note 173 and accompanying text.

180. Heller \& Sofaer, supra note 166, at 27 (emphasis added).

181. Id. at 35 .

182. Id. at 36 .
} 
authority have taken place that are profound and that may fairly be claimed to reflect trends that will ultimately lead to increased sharing of authority with international and private entities." 183 They insist, however, that "[t]his process ... has not deprived states of their predominant authority, and [this process] will continue only with the consent of states as their preferred course for the management of transnational affairs." "184 Perhaps anticipating claims contradicting that position, Heller and Sofaer write that "a widespread perception exists that sovereignty, when understood as autonomous and effective control over national territories, is on the wane," 185 and they acknowledge that "[t]he threat of reduced effective sovereignty has led toward multilevel governance as a prevailing practice, with an unruly mix of regional and functional organizations of overlapping asserted memberships and jurisdictions." 186 Nevertheless, they urge, "states remain the decisive transnational agents" and "the dominant power in both theory and practice in transnational affairs." 187 Indeed, "[a]bsent agreement on what would replace states as the vehicle for transnational governance, a sudden, significant decline in the sovereign powers of states could dangerously destabilize the very processes that sovereignty is currently blamed for obstructing." 188

In short, this excellent analysis by Heller and Sofaer concentrates on states as central to sovereignty. Notwithstanding dramatic changes that have occurred in the international community-and notwithstanding in particular the rise of international organizations generally, the special EU experience, and the broad criticisms that have been directed at sovereignty ${ }^{189}$ - Heller and Sofaer insist that states remain at the center of global governance. But for how long? In their closing paragraph, they hedge their bets on that issue:

Sovereignty is perceived as a concept in crisis and eventual decline because even the more effective nation-states cannot alone satisfy the aspirations of modern, domestic constituencies and have therefore agreed or been forced to share their juridical powers and governmental

\footnotetext{
183. Id. at 41 .

184. Id. (emphasis added).

185. Id. at 39 .

186. Id. at 40 .

187. Id. at 41 .

188. Id. at 45 .

189. Heller and Sofaer survey some of the more prominent anti-sovereignty grounds. Among the observers who say "the notion of sovereignty should be reexamined, deconstructed, or even discarded," Heller and Sofaer cite some extraordinarily well-known international-law experts: Richard Lillich, Richard Falk, UN Secretary-General Boutros Boutros-Ghali, and Louis Henkin (who has asserted that sovereignty should be "decomposed"). Id. at 42 .
} 
functions with other individual and collective actors in an increasing variety of transnational fora. While the future may bring some new concept that replaces sovereignty, that day remains distant. ${ }^{90}$

What Heller and Sofaer do not attempt to predict is how far distant that day is. What I believe emerges from much of the literature I am surveying in this Article - and what my own experience suggests that we have seen in recent years - is that the day when a revised version (if not an entirely "new concept") of sovereignty emerges is not very far in the future. If this is true, then it is incumbent on us to consider what means and models can be followed in order to bring this about.

Before turning, however, to that challenge - and specifically to how such revisions to the concept of sovereignty could bear on global governance relating to agricultural reform and environmental protectionit remains important to give further attention to several other views on sovereignty in its current form. In particular, I should touch briefly on some of the master-works for the subject. I turn to that now.

\section{IF. Other Musings on Sovereignty}

Two major authorities on sovereignty, and on international relations more generally, are Harry Hinsley and Stephen Krasner (the same Krasner whose book Problematic Sovereignty I discussed above in Section IC1 of this Article). Hinsley, who served as a history professor, as Master of St. John's College, and as vice-chancellor at the University of Cambridge, published widely on international relations and on British intelligence operations during the Second World War. His treatise on sovereignty, first published in 1966, is regarded as an excellent survey of how various strands in the evolution of political ideas and of political organization yielded the doctrine of sovereignty. Krasner, who has academic degrees from Harvard, Columbia, and Cornell, is an international relations professor at Stanford University and is a former Director of Policy Planning at the United States Department of State.

In the following paragraphs I highlight some key points made by Hinsley and Krasner in their works on sovereignty. Then I draw from some assessments made a century ago, just as the era of the First World War was creating such a transformation in world-view on the part of many people.

190. Id. at 45 (emphasis added). 
IF1. Hinsley and Krasner: Politics, Sovereignty, Society, and Organized Hypocrisy

A leading light in political theory, Hinsley offered this overall assessment about three decades ago regarding sovereignty, authority, and political power:

Men do not wield or submit to sovereignty. They wield or submit to authority or power. Authority and power are facts as old and ubiquitous as society itself; but they have not everywhere and at all times enjoyed the support or suffered the restraints which sovereignty, a theory or assumption about political power, seeks to construct for them. Although we talk of it loosely as something concrete which may be lost or acquired, eroded or increased, sovereignty is not a fact. It is a concept which men in certain circumstances have applied - a quality they have attributed to a claim they have counterposed - to the political power which they or other men were exercising. ${ }^{19}$

Hinsley then asks what the function has been of the concept of sovereignty - that is, what are "the circumstances . . in which they have resorted to this assumption" that "there was a final and absolute authority in their society," 192 so that power should be thought of in terms of sovereignty. He says this about when the concept has been prominent:

The concept has been formulated when conditions have been emphasizing the interdependence between the political society and the more precise phenomenon of its government. It has been the source of greatest preoccupation and contention when conditions have been producing rapid changes in the scope of government or in the nature of society or in both. It has been resisted ... when conditions, by producing a close integration between society and government... have inclined men to assume that government and community are identical or else to insist that they ought to be. In a word, the origin and history of the concept of sovereignty are closely linked with the nature, the origin and the history of the state. ${ }^{193}$

For Hinsley, then, understanding sovereignty requires understanding the nature of the state. On that point, he makes an important distinction: although sovereignty is not a fact, the state is:

[T] he state — or at least the instrument of power to which we should apply this term-exists in the phenomenal world. Properly used, the state is

191. F. H. HinsLey, SOVEREIGNTY 1 (2d ed. 1986).

192. Id. at 2 .

193. Id. (emphasis added). 
the name we attach to one among the various political institutions which societies develop. It is a distinctive political institution, the particular means of organizing power which societies have adopted at a particular stage in their evolution. ${ }^{194}$

Indeed, Hinsley insists, the growth of the state as an institution dominating the world, particularly since the late 1800 s "has been so enormous, [and] has so overshadowed all other associations, that it has sometimes gone far towards absorbing all the functions of society. This has made it difficult for us to grasp that it [the state] is not the political society itself." 195 Hinsley presses this point emphatically: "the political institutions of societies [such as the state as a political institution] should not be confused with the societies themselves." ${ }^{196}$ In order to explain this point, he notes that in both advanced and primitive societies, the law that emerges from formal political action "is never the sole code regulating social behaviour, and the role of citizen is but one of several roles which each man plays as a member of society."197

In short, Hinsley urges us (i) to regard the state as a political institution that is separate from the society that it "imposes itself on"198 and (ii) to understand that sovereignty is a concept that sometimes - but not always and seldom immediately - "emerges in the wake of the rise of the state." Furthermore, he explains that the concept of sovereignty followed "long after the emergence of the state" in European societies and "it has not yet figured at all in the history of non-European societies." 200 Hence, "while the emergence of the state as a form of rule is a necessary condition of the concept of sovereignty, it is not a sufficient condition of it."201

I have dwelt on Hinsley's views because they underscore the tentative - what I would call the "non-essential" - character of the concept

\footnotetext{
194. Id. at 3.

195. Id. (emphasis added).

196. Id. (emphasis added).

197. Id.

198. Id. at 15. Hinsley characterizes the state as an instrument of power "that is alien to [the] natural ways" of society, and that this is why "the transition to the acceptance of the state has historically been a long and reversible process." Id.

199. Id. at 17. Hinsley notes in this regard that a community of people "may remain segmentary [rather than united] in many respects even after the forms of the state have appeared, and even after they have been accepted, within it" - a fact that explains why "the term 'segmentary state' [has been devised] to connote the intermediate political system in which the administrative forms of the central state and the segmentary organization of power in the society are found in combination." Id. at 18 . As illustrations of such segmentary states, Hinsley mentions the U.S.A. in the eighteenth century and the German empire in the nineteenth century, although he observes that the federal character of both bears on how they developed. Id.

200. Id. at 21 .

201. Id. (emphasis added).
} 
of sovereignty. In his account (which is worth knowing because of the reputation he has as an authority on such subjects), sovereignty (i) is obviously separate from and subsidiary to the state, (ii) is present and robust in modern history but should not be regarded as somehow having a monopoly over the ways of characterizing the relationship between the state and the exercise and expression of authority. Recall that earlier in Section IC, under the subheading "default-setting sovereignty," we saw that some observers urge that sovereignty is most appropriately regarded as also being partly optional, in the sense that states can opt out of it in certain circumstances. Hinsley would presumably concur in that view and then double down, saying that states need not have opted into it in the first place, although as a practical matter most modern states have done so.

Having set those markers in place for the relations between society, the state, and sovereignty, Hinsley embarks on a historical review to explain how the concept of sovereignty-working in some cases against heavy odds - has in fact achieved such strength as to dominate today's globe. His survey emphasizes the "prehistory" of the concept, including contributions made in the Roman period ${ }^{202}$ and in medieval Europe, ${ }^{203}$ and he naturally explains the roles played by figures whom I mentioned earlier, including Bodin, Hobbes, and Rousseau. ${ }^{204}$

Hinsley then turns to international relations. He summarizes, at the beginning of a chapter titled "The Concept of Sovereignty in the History of Relations Between States," why sovereignty cannot apply to a level higher than that of the state:

Applied to the community, in the context of the internal structure of a political society, the concept of sovereignty has involved the belief that there is an absolute political power within the community. Applied to the problems which arise in the relations between political communities, its function has been to express the antithesis of this argument-the principle that internationally, over and above the collection of community, no supreme authority exists. ${ }^{205}$

This should not be surprising, Hinsley explains: "The idea that there is a sovereign authority within the community carries with it - at least it leads to - the idea that this authority is one among other authorities ruling

\footnotetext{
202. See id. at $27-44$.

203. See id. at $45-125$.

204. See id. at 120-25, 141-57. For my summary account of the work of Bodin, Hobbes, and Rousseau, see supra Section IA of this Article, especially text accompanying note 18, and supra Section IA2, especially text accompanying note 78.

205. HINSLEY, supra note 191, at 158 (emphasis added).
} 
in other communities in the same sovereign way." ${ }^{206}$ Consequently, in the international context the concept of sovereignty has "denied that there exists above the community a supreme power."207

Hinsley seems somewhat bemused, therefore, at the fact that mighty efforts have been made to reach a different outcome, in which sovereignty could somehow be applied to, or found in, some authority outside and above the state. He explains such efforts as they appeared in Rome and in Medieval Europe ${ }^{208}$ — especially as they centered on the theories of the ius civile, the ius gentium, the ius fetiale, and ius natural, ${ }^{209}$ and how they evolved into the highly influential formulation offered by Hugo Grotius, who found a structure of binding rules among states in the blend of ius gentium voluntarium (derived from human positive law) and a "law of nature" whose character "Grotius left ... ambiguous" but which seemed to consist mainly of "the general principles that conformed to the best elements in man." "210 Grotius, Hinsley notes, "was the first man to insist on the need for a body of positive international law, separate from the natural law and deriving from the will and practice of states"; in this way, Grotius' De Jure Belli ac Pacis "was the first systematic treatise on this [international] law."211

But Grotius was not able to find or create universal sovereignty. Hinsley explains that the "problem which [lay] at the root of Grotius's confusion" was this: Given the fact "that the international society lacked the legal sanctions which served [to enforce rules] in the single state, [and that] it lacked the single state's legislative, judicial and government organs and its social cohesion,... [w] here in a world of sovereign states was [some higher form of] restraint to be discovered" that would constitute something like the sovereignty found in the individual states? ${ }^{212}$ Nowhere, Hinsley would answer. As a consequence, "the frequent lament since the eighteenth century ... [is] that in a hundred or one hundred and fifty or even two hundred and fifty years the ideas of men like Grotius ... have

\footnotetext{
206. Id.

207. Id.

208. See id. at 161-86.

209. The ius civile was the law made by the citizens of Rome to govern their affairs; the ius gentium, closely linked with the widely received notion that there was a law of nature, was the name given to those elements or principles that seemed to be common to the various customary laws of the Mediterranean local communities which lay beyond Rome; and the ius fetiale, named after the fetial priests of the city, consisted of the solemn forms to which it was proper to conform when the city was conducting relations - making war and concluding treaties-with other communities. Id. at 161-62. For Hinsley's discussion of ius naturale, see id. at 180-83.

210. Id. at $188-89$.

211. Id. at 189.

212. Id. at 196.
} 
had little or no influence on the practice of states." ${ }^{213}$

Hinsley explains that despite the fact that the concept of state sovereignty excludes, by its own logic, the discovery or imposition of some authority higher than the state, efforts have been made, especially in times of global crisis, to fight against this logic. In some cases, the efforts have reflected opinions in favor of "limit[ing] or even abolish[ing] the sovereign independence of the separate state by institutional means." This opinion, he says, "played a decisive part in shaping the League of Nations." 15 That institution failed, Hinsley says, because "it sought ... to avoid ... the recurrence of war, by the suppression or the limitation by external means of the sovereignty of the individual state at a time when the outstanding development of recent history had been the increase in the power, the scope and the efficiency of the individual state." 216

In Hinsley's view, the UN "has as yet been no less a failure" than the League was ${ }^{217}$ - again, because of the continuing vitality of the concept of sovereignty. Hinsley was writing during the Cold War (the second edition of his book was published in 1986, revising the original 1966 edition), and his view of the continuing vitality of sovereignty also appears in the last pages of his book, where he commented on the conflict between the U.S. and the USSR, the two superpowers of the day. ${ }^{218}$ According to Hinsley, the strength of the concept of sovereignty could be seen in the fact that "their [actual] abstention from war with each other for the past forty years" 219 is based on an informal "doctrine of peaceful co-existence... [which] pronounces that while rivalries are inevitable between societies having different structures and different ideologies, those rivalries must for ever be kept short of war by the states." 220 With what seems to be an air of resigned realism, Hinsley remarks that "this is not much to go on."221

Writing about a decade and a half more recently than Hinsley, Stephen Krasner reflects some later developments but underscores the same conflict between the realities of sovereignty and the desires (by some) of global regulation of state power. In a book that Krasner wrote two years before his Problematic Sovereignty book (discussed above in Section IC1

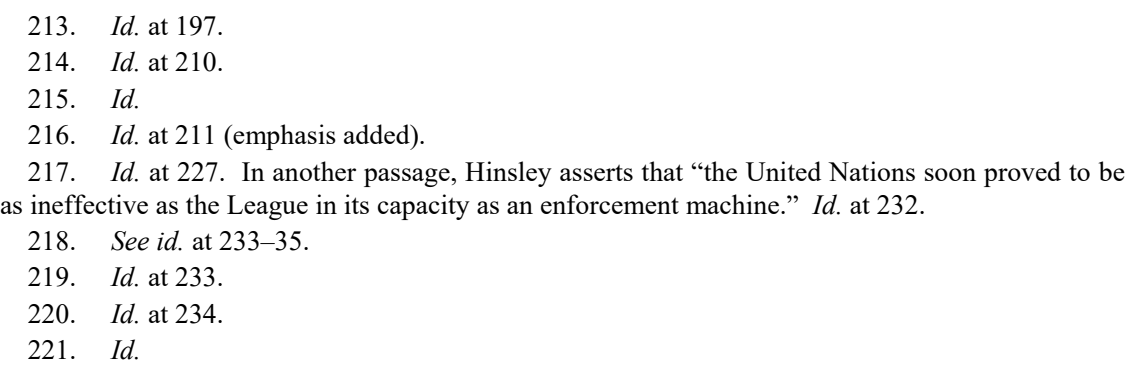


of this Article), Krasner gives this overview of the current status of sovereignty:

Some analysts have argued that sovereignty is being eroded by one aspect of the contemporary international system, globalization, and others that it is being sustained ... by ... the mutual recognition and shared expectations generated by international society. Some have pointed out that the scope of state authority has increased over time, and others that the ability of the state to exercise effective control is eroding. Some have suggested that new norms, such as universal human rights, represent a fundamental break with the past, while others see these values as merely a manifestation of the preferences of the powerful. ${ }^{222}$

Krasner then explains that this "muddle" in the manner in which various analysts view sovereignty in today's world "reflects the fact that the term 'sovereignty' has been used in different ways." 223 He elaborates by emphasizing the four variants seen earlier: international legal sovereignty, Westphalian sovereignty, domestic sovereignty, and interdependence sovereignty. ${ }^{224}$ The second of those-Westphalian sovereignty, which occupies most of his attention in his 1999 book on sovereignty as "organized hypocrisy"-refers to "political organization based on the exclusion of external actors from authority structures within a given territory." 225

A central theme Krasner develops is that Westphalian sovereignty has been widely surrendered - so much so that it is rather hypocritical to continue regarding it as conceptually valid in today's world. For instance, he asserts that "[i]nternational financial institutions [IFIs], such as the World Bank and the International Monetary Fund, have institutionalized and routinized practices that are inconsistent with Westphalian autonomy" because those IFIs "do not simply offer funds on the condition that they be repaid; they extend resources only if borrowers are willing to accept changes in their domestic policies and often institutional structures as well."226

Human rights, Krasner writes, can also be seen as an area in which

222. STEPHEN D. KRASNER, SOVEREIGNTY: ORganized Hypocrisy 3 (1999) [hereinafter ORGANIZED HYPOCRISY].

223. Id.

224. See supra note 122 and accompanying text.

225. ORGANIZED HYPOCRISY, supra note 222, at 3-4.

226. Id. at 34-35. He singles out the European Bank for Reconstruction and Development (EBRD) in particular, saying that its lending is conditional upon borrowing states accepting democratic principles and reforms. Id. at 35 . 
Westphalian sovereignty has been violated. ${ }^{227}$ Indeed, Krasner asserts, Westphalian sovereignty has been surrendered through bargaining "that affected basic constitutional structures, not just specific institutions or policies" such as human rights. ${ }^{228}$ In this regard, Krasner explains that "American practices in Italy and Germany after the Second World War involved contracts with national leaders that were designed to promote democratic regimes, or at least to exclude or repress Communist influence; national leaders invited the influence of their American counterparts."229

Some instances of bargained-away Westphalian sovereignty resulted not just in a limitation in the discretion of national leaders (restricting their ability to mistreat minorities, for instance, or to undermine democratic processes) but also in a sharing or blending of sovereignty. This appears, Krasner posits, in the case of the EU, which he says "has been created through contracts entered into by the rulers of the European states," who have thereby "establish[ed] new policies and institutional arrangements, some of which transcend territorial boundaries and compromise their domestic autonomy."230

A similar instance of shared or blended authority emerging from what Krasner considers a bargaining away of Westphalian sovereignty appears in the case of the law of the sea. Specifically, the rules established in the 1982 United Nations Convention on the Law of the Sea permit a coastal state to claim an Exclusive Economic Zone (EEZ). ${ }^{231}$ "Within the EEZ [a coastal state does] ... have authority over mineral and fishing resources, but ... [it does] not have control over shipping." ${ }^{232}$ Krasner argues that although this EEZ regime "does not violate autonomy" because "there is no exercise of external authority,... it does violate territoriality by creating an area within which states have authority over some issues but not others." 233

What Krasner offers in these illustrations is a body of evidence supporting one of the overarching themes of his book - that what he calls "Westphalian sovereignty" should be regarded as an "example[] of organized hypocrisy," in the sense that even though the concept makes sense and is regarded as highly important, it has persistently been

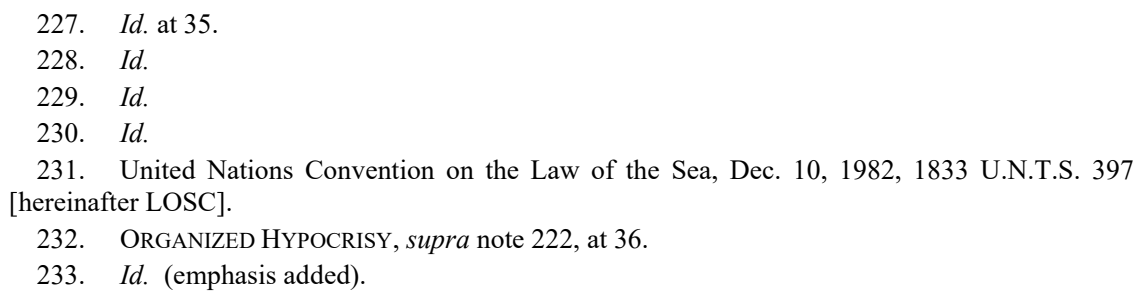


violated. ${ }^{234}$

But how can it be true that both (i) Westphalian sovereignty is widely accepted as at least a rhetorically strong and vibrant concept of central importance to the international system and (ii) Westphalian sovereignty is regularly violated? Krasner explains that the so-called "English school" of thought asserts that international norms such as those encompassed by "Westphalian sovereignty" can persist despite frequent violations because "an international society is the product of a shared civilization" for which "there must be 'an international social consciousness, a world-wide community sentiment.",235 Krasner elaborates on what this "English school" view asserts about where such an "international social consciousness" can be found in today's world:

For the English school, ... [t]he contemporary sovereign state system is a product of beliefs that are rooted in Christian notions of natural law. These European concepts have spread, to one extent or another, to other areas of the world. Where there is no shared civilization, no shared sense of values, there is no international society, although there may be an international system, a situation in which there is interaction but no constraining norms. According to the English school, there were, for instance, no common rules affecting relations between Genghis Khan and those he conquered, between the Spanish and the Aztecs, or between the Christian and Moslem worlds.

Krasner questions the validity, though, of the "English school" view that today's international system - unlike those that existed at the times of Genghis Khan or the Spanish invasion of Aztec civilization or the early rise and expansion of Islam - enjoys some sort of shared values or takenfor-granted norms. "It is . . difficult," he writes, "to find any practices in the international system that are consistent with the notion that there are some norms that are taken for granted.... Rules as apparently uncontested as the treatment of diplomats have been grossly violated," as in the case of Iran's seizure in the late 1970s of the U.S. diplomats. ${ }^{237}$ This

234. Id. at 40 (emphasis added). There are four means by which "Westphalian sovereignty" has been violated, Krasner says: "through conventions, contracting, coercion, and imposition." Id. The illustrations offered here, involving IFI lending, human rights, national constitutional structures, EU institutional arrangements, and the EEZ regime, are all contractual and conventional in nature.

235. Id. at 47 (citing Martin Wight, Western Values in International Relations, in DIPLOMATIC INVESTIGATIONS: ESSAYS IN THE THEORY OF INTERNATIONAL POLITICS 96-97 (Herbert Butterfield \& Martin Wight eds., 1968).

236. Krasner, supra note 222, at 47-48 (emphasis added). Krasner explains that some other schools of thought - he cites the constructivist school and the Yale school of international law in this regard-also assert "that international relations can only be understood from a perspective that emphasizes shared norms and values." Id. at 48.

237. Id. at 51 . 
and other incidents leave Krasner convinced "that the shared norms and internalized constraints stipulated by the English school do not exist." "238

For this reason, along with others that Krasner explores, he concludes that sovereignty - at least what he calls "Westphalian sovereignty" and "international legal sovereignty"- should be regarded merely as "examples of organized hypocrisy": "Their defining rules have endured and been widely recognized and endorsed but, at the same time, sometimes compromised-in the case of Westphalian sovereignty, frequently compromised." 239

Why does this matter? That is, why might we care that Krasner applies the label "organized hypocrisy" to the type of sovereignty that we are examining here? Because Krasner has a highly-respected reputation in the area of international relations generally and has drawn his conclusions after undertaking a careful study based on extensive scholarly literature and professional experience. His "sovereignty as hypocrisy" views, as set forth in a work that was followed two years later by his Problematic Sovereignty book, add further weight to the sentiments explored thus far in this Article, namely that sovereignty is definitionally sloppy, frequently disregarded or set aside, most popular in its coarse and distasteful "macho" form, and extremely difficult to defend (despite Stankiewicz's efforts to do so, as explained above in Section IB2) against charges that it is absolutist, anachronistic, and otherwise unsuitable for use in the modern world.

\section{IF2. Lansing and Laski: Views From a Century Ago}

Disagreements and uncertainties over sovereignty-what it means, what values it protects, what innovations it suppresses - are hardly new. Before bringing this analysis of sovereignty to a close, it is worth looking briefly at two views of sovereignty from a century ago. One comes from Robert Lansing, an American lawyer who served as legal advisor to the U.S. Department of State at the time of the First World War, and later as Secretary of State under President Woodrow Wilson. ${ }^{240}$ Before that,

\footnotetext{
238. Id. at 55 .

239. Id. at $71-72$.

240. It was Lansing who has often been quoted as having advised President Wilson in 1919 that "[t]o declare war is one of the highest acts of sovereignty." See, e.g., José Sette-Camara, Methods of Obligatory Settlement of Disputes, in INTERNATIONAL LAW: ACHIEVEMENTS AND PROSPECTS 520 (Mohammed Bedjaoui, ed. 1991). Lansing has also been quoted as having remarked, in conjunction with his role as a member of the Paris Peace negotiation team in 1919, that "the essence of sovereignty is the absence of responsibility." Jurgen Brauer \& Robert Haywood, Non-state Sovereign Entrepreneurs and Non-territorial Sovereign Organizations, Working Paper No. 2010/09, United
} 
Lansing had built his reputation as an authority on international law by serving as counsel for the U.S.A. in various boundary and fisheries arbitrations; he also served as an editor of the American Journal of International Law. The other set of views comes from Harold Laski, a British economist, politician, and lecturer who became a widely known intellectual spokesman for socialism in the years between the two world wars. Laski lectured in history at Harvard, McGill, and Yale Universities and wrote widely on sovereignty, authority, and political theory generally.

In his Notes on Sovereignty, written between 1907 and 1921 and collected for publication in 1921, Robert Lansing offers several key points. First, he asserts that sovereignty is essential to society: "The organization of a political society without the operation of sovereignty is as incomprehensible as a creation without a creator, as a thought without the mind from which it sprung." ${ }^{241}$ Second, although he acknowledges the difficulties inherent in providing a definition of something so fundamental as sovereignty, Lansing "defines sovereignty in its broadest sense as the power to do all things without accountability." 242 Third, from that broad definition, he offers refinements involving discussions of "Divine sovereignty" and then "human sovereignty" - the latter of which he defines as "the power to the extent of human capacity to do all things on the earth without accountability" 243 and which he says "prevails in a state." 244

With these efforts to define the scope of sovereignty, Lansing then describes its substance. For this, he focuses on force. "Sovereignty is real," he writes, "only when the possessor can compel the obedience ... of every individual composing the political state and within the territorial state." 245 Moreover, this power to compel obedience "necessarily arises from the possession of physical force superior to any other such force in the state" and indeed it is "the application or the menace of brute force," he asserts, that is involved in the exercise of sovereignty in a state, with regard for "rational, equitable, and ethical ideas" being only

\footnotetext{
Nations U. (Feb. 2010), https://www.wider.unu.edu/sites/default/files/wp2010-09.pdf [https://perma. cc/CU4X-T4LY], at 6 (citing GaReth Evans, The Responsibility to Protect: ENDING Mass ATROCITY CRIMES ONCE AND FOR ALL 8 (2008)).

241. ROBERT LANSING, NOTES ON SOVEREIGNTY 2 (1921).

242. Id. at 3 .

243. Id.

244. Id. at 4. It is this state sovereignty that Lansing says "history knows and law recognizes, [and it is] the sovereignty which ... is the force constantly at work forming and reforming political institutions and regulating human conduct." Id.

245. Id. at 7 .
} 
"discretionary" on the part of the possessor of sovereignty. ${ }^{246}$

Those views reflect a hearty embrace of positivism as espoused by John Austin. Indeed, Lansing cites Austin in asserting that "law in a state is a rule of human conduct emanating from the sovereign." 247 This Austinian view has been largely abandoned in the last century, as have some other propositions that might strike us as curious today. For instance, Lansing offers these observations:

The body of individuals [possessing sovereignty] in a state ... is not restrained in any way ... in declaring the fundamental law of the state. They may, indeed, if they so will, [take actions] which are manifestly unjust and immoral. It is not at all a question of right, but a question of power....

As it is impossible, except when actual physical strife occurs in a state, to determine with certainty who are and who are not the possessors of the real sovereignty, there are certain qualifications which have been assumed in modern states to be evidence of an individual's right to share in the exercise of the sovereignty.

These qualifications are usually based, whether intentionally or not, upon the presumptive physical strength of the individual. They are as follows: First, Sovereign [sic] rights are confined to males, because ... females are physically inferior and therefore powerless to maintain such rights by force. Second, The [sic] males are also limited to those who are presumed to have attained full bodily vigor, which is assumed to be when they have reached a certain age. ${ }^{248}$

Having thus asserted that sovereignty rests entirely on power, not right, and that it cannot involve participation by females, and likewise that it cannot involve participation by minors, Lansing draws an analogy between (i) individual human beings in a state and (ii) the states, territories, and colonies that comprise a federal system such as the U.S.:

[T] he individual states in a federal state like the United States stand in the same relation to the federal sovereignty that the male citizens of legal age stand to the sovereignty in a single state. To carry the analogy further in the case of the United States - the territories of the United States are similar to citizens of the male sex in a single state, who are minors, but

246. $I d$.

247. Id. at 45 (quoting JOHN AUSTIN, LeCTURES ON JURISPRUDENCE 79 (Robert Campbell ed., London, John Murray, 5th ed. 1885). In particular, Lansing quotes Austin's assertion that "[1]aws proper, or properly so called, are commands." Id. Other observers have characterized Austin's view of law as a set of orders issued by a sovereign and backed by force or the threat of force. H.L.A. HART, THE CONCEPT OF LAW 18-20 (1960).

248. LANSING, supra note 241 , at 20-21. 
who will in time attain to equality in sovereign rights; and colonies are like the females in a state, who owe it allegiance but lack the inherent qualities to become possessors of the sovereignty. ${ }^{249}$

To most readers in the early twenty-first century, the views that Lansing presents from the early twentieth century seem antiquated and perhaps offensive. Some other views he expresses might, on the other hand appear naïve or imperialistic, depending on one's perspective. Having discussed "the characteristics of qualities of the sovereignty which finds expression in a state," Lansing then turns his attention to "the more extensive type of sovereignty which affects politically the entire human race and territorially the whole earth." $" 250$

In this regard, Lansing seems to endorse the view "which sees in the world but a single social organism [that is] all-inclusive and universal" and that possesses "a sovereignty that is superior to the sovereignty in a state." "251 Lansing acknowledges that such sovereignty is only "unformed and necessarily a theoretical conception" at the time he was writing, but he says that "powerful political and moral influences are at work in the world to change the theory into practice"-and an appreciation of this fact "compels the conviction that the entire human race ought to be considered, and in fact is, a single community, which awaits the further development of modern civilization to complete its organization and make of all mankind a great, universal political state. ${ }^{~ 252}$ Already, Lansing asserts, in the currently "unorganized mass of humanity there must be a certain body of individuals possessing a physical might sufficient to compel obedience by every member of the human race throughout the world. Such superior physical might constitutes sovereignty, and, since its only limit is the earth, it may properly be termed World Sovereignty." 253

From this assertion that there is a strong momentum toward world sovereignty, Lansing draws what might be a logical conclusion: the expression of such world sovereignty will be "the organization of a World State - an idea that he says has been envisioned many times in the past but has not been possible until the present age (that is, the early twentieth century when Lansing was writing). ${ }^{254}$ As evidence of the momentum (what he calls the "tendency of modern thought") toward such a world

\footnotetext{
249. Id. at 26 .

250. Id. at 55 .

251. Id. at 56 .

252. Id.

253. Id. at 57 .

254. Id. at 58 .
} 
state, Lansing points to the fact that the individual nations of the world had already largely accepted the "fiction" of legal equality of states. ${ }^{255}$

Lansing's views on sovereignty and global unity were not shared, of course, by all of his contemporaries. Harold Laski offers a sharp contrast. Writing in 1916, Laski opens his book Studies in the Problem of Sovereignty ${ }^{256}$ with a broadside attack on assertions of global unity and world sovereignty. ${ }^{257}$ After acknowledging, with citations to Hegel, Dante, and two Catholic popes, the strong appeal that such ideas of unity and concentration of power and loyalty do hold for some persons, ${ }^{258}$ Laski dismisses these ideas as both unrealistic and, on careful reflection, repulsive. ${ }^{259}$ Put simply, our loyalties, our allegiances, our identities, are not monolithic but pluralistic.

In the event of a great war, for example, as a member of the State you may be called upon to fight; as a member of another group, the Quakers, you may be called upon to resist that demand. It seems clear that little is gained by talk of 'over-riding demands,' of saying, for instance, that the demands of the State are all-important. They are all-important only to the State. The history of societies fatally contradicts the view that in a crisis only the State will have power of compulsion. What of certain miners in South Wales? What of certain Unionists in Ulster? Of militant suffragists? Did not to them the wills of certain groups other than the State conflict with it and prove more intense in their demand? 260

Laski then makes a frontal attack also on positivism. As noted above, Robert Lansing relied heavily on John Austin's form of positivism in asserting that law is "a rule of human conduct emanating from the sovereign." ${ }^{261}$ Laski dismisses this as nonsense. Law "clearly is not a

255. Id. at 67. As further evidence of the momentum toward a world state and "a manifestation of the existence of a sovereign will in the world," Lansing cites the international adoption of policies relating to piracy and the slave trade. $I d$. at 74 .

256. Harold J. Laski, Studies in the Problem of Sovereignty (Howard Fertig ed. 1968) (1917).

257. Id. at $1-9$.

258. See id. (noting "the temptation that bids us to make our State a unity" and suggesting that "we tend, in our political thinking, to adopt a sort of mystic monism as the true path of thought" and noting that the notion of state sovereignty emerges because "[t]he State must triumph and has need of some organ whereby its end may be attained").

259. Id. at 11-12.

260. Id. Laski's mention of "certain coal miners in South Wales" probably refers to members of unions - such as the South Wales Miners' Federation, formed in October 1898 following the defeat of the South Wales miners' strike of 1898. Id. By 1914, just before Laski wrote on sovereignty, the SWMF had tens of thousands of members. See generally RoBIN PAGE ARNOT, SouTH WALES Miners, Glowyr de Cymru: A History of the South Wales Miners’ Federation (1914-1926) (1974).

261. See supra note 247 and accompanying text. 
command," he says. Instead, "[w] here sovereignty prevails, where the State acts, it acts by the consent of men" 262 and not because of force.

If, for example, Parliament chose to enact that no Englishman should be a Roman Catholic, it would certainly fail to carry the statute into effect. We have, therefore, to find the true meaning of sovereignty not in the coercive power possessed by its instrument, but in the fused good-will for which it stands. Men accept its dictates either because their own will finds part expression there or because, assuming the goodness of intention which lies behind it, they are content, usually, not to resist its imposition. ${ }^{263}$

For Laski, then, the concept of a unitary, absolutist, all-powerful state with a heavily-muscled form of sovereignty that shoulders aside all competing loyalties and authorities "runs counter to some of the deepest convictions we can possess." 264 Discarding that "monistic" view in favor of what he calls a "pluralistic theory" would, Laski argues, be in keeping with "the consistent disruption of absolutisms" that he says has occurred in both "the realm of philosophy" and "the sphere of politics." $265 \mathrm{He}$ presses further:

The history of recorded experience seems to show that this kind of dogma [i.e., clinging to absolutisms such as the monistic view of state sovereignty] is the stumbling-block in the way of all progress. The State has sovereign rights; and those who manipulate it will too often cause it to be used for the protection of existing rights. The two get identified; the dead hand of effete ancestralism falls with a resounding thud on the living hopes of to-day. ${ }^{266}$

Laski acknowledges how radical a departure it is that he is proposing from Hobbesian views of sovereignty and from the prevailing view of state authority. After all, Laski's pluralistic theory suggests that whatever loyalty individuals will show toward the state in whose territory they live is ultimately voluntary in nature, based on their view of how creditworthy that state's actions are. And anarchy poses a threat to sovereignty. ${ }^{267}$

I am well enough aware that in any such voluntarism as this room is left for a hint of anarchy. To discredit the State seems like enough to dethroning it. And when the voice of the State is viewed as the deliberate expression of public opinion it seems like the destruction of the one

\footnotetext{
262. Laski, supra note 256, at 12.

263. Id. at $12-13$.

264. Id. at 21.

265. Id. at 21-22.

266. Id. at 22 .

267. Id. at 24 .
} 
uniquely democratic basis we have thus far attained. But the objection, like the play queen in Hamlet, protests too much. It assumes the homogeneity of public opinion, and of that homogeneity not even the most stout-hearted of us could adduce the proof. Nor is its absence [that is, the absence of homogeneity in public opinion, actually a] defect. On the contrary, it seems to me that it is essentially a sign that real thought is present. A community that can not agree is already a community capable of advance....

I imagine the absolute Hobbes, who has seen internal dissension tear a great kingdom in pieces, holds up hands of horror at such division of power. [Still, it is difficult to agree] with that prince of monistic thinkers.... [After all, it] is from the selection of variations, not from the preservation of uniformity, that progress is born .... We shall make the basis of our State consent to disagreement. Therein shall we ensure its deepest harmony. ${ }^{268}$

Fortunately for us, Laski gives direct attention to federalism. In a special appendix offering "a note on sovereignty and federalism," he asserts that the U.S. Constitution actually declines "to erect an instrument of sovereign power" for the country. ${ }^{269}$ In the U.S. system, Laski writes, "[w]e do not know who rules. Certainly the president is not absolute. Neither to Congress nor to the Supreme Court is unlimited power decreed." ${ }^{270}$ Faced, he says, with the challenge of reconciling sovereign claims from both (i) the national authorities and (ii) the individual constituent states, "[t]he [founding] fathers reconciled these opposites by abolishing altogether any notion of Austinian sovereignty." ${ }^{271}$ Even the Constitution itself, Laski urges, is a narrowly limiting instrument that by its very nature - written, specific, and rigid-flies in the face of a fullthroated sovereignty that Austin and his adherents would grant to the state. ${ }^{272}$

Then Laski sums up his views. He says that "sovereignty, rightly regarded, ought not to be defined as omnicompetence at all."273 Instead, its exercise is "an act of will behind which there is such power as to make the expectation of obedience reasonable" but not a foregone conclusion. ${ }^{274}$ Regarded in this way, sovereignty "is, after all, not such a very formidable thing"; and specifically, "the sovereignty of the state does not in reality

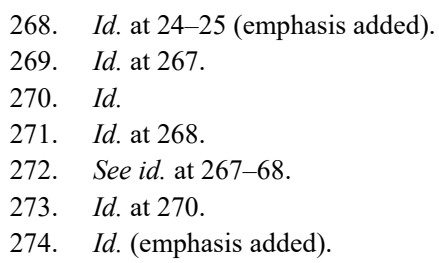


differ from the power exercised by a Church or a trade union"275 In the end, he says, "[w]e begin to see the State as akin to that medieval empire which was above all a community of communities. The sovereign appears as a thing consistently to revere rather than as a thing undeviatingly to obey." 276

\section{IG. Negotiated Innovation and Pluralistic Sovereignty}

Imagine Robert Lansing reading Harold Laski's account of sovereignty. Lansing would have found it alarming, maybe even goofy. As Laski himself said, Hobbes would probably "hold up hands of horror" at Laski's pluralist and rather casual view of sovereignty. Some of the authorities I have surveyed thus far in this Article would doubtless do the same-W. J. Stankiewicz comes to mind, given the ambitious defense of traditional sovereignty that he mounted. ${ }^{277}$ For those observers, sovereignty is real, robust, muscular, monolithic, and crucial to the international system.

Laski's dramatically different view, though, would also attract many endorsements. Whatever they might think of Laski's political views more generally, ${ }^{278}$ some of the observers I have cited above-Jens Bartelson, ${ }^{279}$ Jacques Maritain, ${ }^{280}$ Staley Benn, ${ }^{281}$ Kenneth Cole, ${ }^{282}$ and Stephen Krasner $^{283}$ come to mind in particular-would probably find Laski's hundred-year-old views on sovereignty quite palatable and (as I do) rather

\footnotetext{
275. Id. He continues:

The force of a command from the State is not, therefore, bound to triumph, and no theory is of value which would make it so. When Germany orders its subjects to refrain from the discussion of peace terms it may enforce its rule when only Rosa Luxemburg or Liebknecht is concerned; it could not do so were the Socialists as a whole to rebel. Id. at $270-71$.

276. Id. at 274 .

277. See supra Section IB2.

278. Harold Laski encountered considerable criticism and even rebuke during his career. Having first promoted the form of pluralism reflected above, he shifted after 1930 to a Marxist emphasis on class conflict and the need for a workers' revolution, which he hinted might be violent. Laski's position angered Labour leaders who promised a nonviolent democratic transformation. Laski's position on democracy came under further attack from Winston Churchill in the 1945 general election, and the Labour party had to disavow Laski as its chairman. For details, see BILL JONES, THE RUSSIA Complex: The British Labour Party and the Soviet Union 16 (1977); KenNeth Hoover, ECONOMiCS AS IDEOLOGY: KeYNES, LASKI, HAYEK, AND THE CREATION OF CONTEMPORARY POLITICS 164 (2003).

279. See supra Section IB1.

280. See supra Section IB2, and particularly text accompanying notes 60-83.

281. See supra note $91-93$ and accompanying text.

282. See supra note 94-105 and accompanying text.

283. See supra Sections IC1 \& IF1.
} 
refreshing. Indeed, maybe even Thomas Heller and Abraham Sofaer, viewing sovereignty from their international-law-practitioner perspective, would find themselves agreeing with Laski's emphasis on pluralism, at least to the degree that such pluralism reflects the notions of "interdependent sovereignty" 284 and the process by which "certain aspects of sovereign power are shared or relocated." 285

Even so, the fact remains that in general discourse the concept of sovereignty retains tremendous power. For many of its proponents, especially advocates of what I referred to above as "macho sovereignty," ${ }^{286}$ sovereignty constitutes - both in its exercise and its defense - a high-pressure, high-profile, high-energy, high-stakes affair. Those persons are unlikely to be moved to discard the term "sovereignty" and the concept they think it names, even in the face of evidence that it is definitionally sloppy, historically suspect, frequently disregarded or set aside, and widely unattractive for its embrace of monolithic power and its fealty to absolutism.

Given this reality, any attempt to proffer a new version of sovereignty that would reflect the circumstances of the modern age - and that would, perhaps more importantly, anticipate a new age in which agriculture is practiced differently and environmental restoration is a fundamental and non-derogable value - probably needs to retain the term "sovereignty" in some respect. As an acknowledgement of that fact, I have settled on the term "pluralistic sovereignty." Let me offer the following one-paragraph synopsis before giving some further attention to sovereignty's sisterconcept, which is the concept of the so-called nation-state.

Instead of a concept of sovereignty based on an assumption of autonomous territorial isolation and on the pretension of a singular nationality, a new and more realistic version of sovereignty for today's world would be pluralistic in its outlook - both (i) in the expectation that authority over specific territories of the Earth's surface would be shared and blended (as is already true in important respects and becoming increasingly so for good reason) and (ii) in the realization that multiple types of authorities (not just so-called "nation-states" of the sort emerging from European circumstances of several centuries ago) can naturally and legitimately exercise sovereignty. Such a "pluralistic sovereignty" would rest on the two pillars of innovation and negotiation, in the sense that it would both (i) aggressively seek new solutions, including technological solutions, to governance issues in an increasingly complex and integrated

\footnotetext{
284. See supra note 175 and accompanying text.

285. See supra note 181 and accompanying text.

286. See supra Section ID.
} 
world, and (ii) result from participation by an unprecedented breadth of persons and entities whose interests are to be taken into account in addressing such governance issues. Ultimately, the "pluralistic sovereignty" that would emerge from such negotiated innovation has as its aim to create and reflect a governance structure that would have a set of entities, loyalties, authorities, and responsibilities suitable for the modern age - with special attention to the existential ecological crises that this modern age presents.

To that one-paragraph synopsis of what I call "pluralistic sovereignty," let me add two other brief points before turning to my discussion of the nation-state. The first point is historical in character; the second focuses on the climate crisis and the agriculture crisis.

Historically, a system of "pluralistic sovereignty" would resemble the political and social landscape found in Europe before the rise of the nationstate, when people found themselves answering to numerous cross-cutting loyalties. In that setting, these loyalties might run simultaneously to a local prince, a more distant king, the parish priest, a group of village elders, and perhaps a guild - all of which were recognized as having some rulemaking authority over specified subject-matters. ${ }^{287}$ My view of "pluralistic sovereignty" is similar: authoritative rules would emerge from (and be enforced by) more than one entity, depending on the subjectmatter at issue.

Environmental protection is a specific subject-matter of primary concern to me in this regard. Given the crisis I see in our present form of agriculture - a matter I have explored in detail elsewhere ${ }^{288}$ — coupled with the related emergency that we face in the way of unprecedented climate disruption, ${ }^{289}$ I believe "monolithic sovereignty" falls short. Effective and authoritative sources of rule-making and rule-enforcement should be established to address these existential challenges. Indeed, looking beyond the concept of sovereignty to the concept of the nation-state, I find the latter entirely adequate for meeting these challenges, and I have

287. For a discussion of "pluralism" in a legal sense before the rise of powerful nation-states, see John W. Head, Great Legal Traditions: Civil Law, Common LaW, and Chinese Law in HistoricAl AND OPERATIONAL PERSPECTIVE 85-86 (2011).

288. For my explanation of economic, ecological, and social unsustainability of what I describe as modern extractive agriculture, see HEAD-2017, supra note 4, at 39-133. As noted there, my views draw from a wide range of authorities on the history and practice of agriculture, especially from an ecological perspective.

289. At the outset of this Article, I offered some observations about the impact of the climatechange crisis on Kansas. For a more general explanation of the relationship between the climate crisis and the agricultural crisis, see HEAD-2017, supra note 4, at 98-103 (cataloguing the many ways agriculture contributes to climate disruption) and 340 (referring to the "risk of crop yield reductions as the world warms"). 
proposed a parallel structure - that of the "eco-state." Let us turn to that topic now.

\section{OVERCOMING THE ANACHRONISM OF THE STATE AND NATIONALISM}

What I have tried to establish in Part I of this Article is that the concept of sovereignty is deeply flawed, historically anachronistic, impossible to define effectively, and worthy of dismissal. Its saving grace, if any, is that the sheer persistence of the concept of sovereignty (for now, at least) in the vocabulary of international law and international relations augurs against discarding it entirely and toward adopting instead a notion of "pluralistic sovereignty" that reflects what I have called "negotiated innovation" in establishing various forms of political organization and authority in the world. As I have explained in a preliminary way elsewhere, the exercise of such "pluralistic sovereignty" in the context of agriculture and environmental restoration would involve introducing a novel fundamental political unit—what I call the "eco-state." 290 Because traditional sovereignty has been exercised by the so-called "nation-state," I turn for the remainder of this Article to an examination of that concept, as well as the concept of nationalism that lies at its heart.

I use the somewhat disparaging adjective "so-called" (that is, the "socalled" nation-state) because what my examination reveals, among other things, is that there really is no such thing, technically speaking, as a true nation-state. More important, though, than this matter of terminology is the fact that the nation-state as a concept is the obsolete remnant of a longpast era that bears little resemblance to today's world. It shares this characteristic with sovereignty. It also shares another characteristic with sovereignty: the concept of the nation-state, like the ideology of nationalism that lies at its heart, does us more disservice than service because it involves serious flaws that distort our understanding of modern international relations and how they can be improved. These and other points I explain in the following paragraphs, beginning with the concept

290. See HEAD-2017, supra note 4, at 373-74, 379. As I explained there, the term "eco-state" does not originate with me. See, e.g., James Meadowcroft, From Welfare State to Ecostate, in THE StATE AND THE Global Ecological CRISIs 3-23 (John Barry \& Robyn Eckersley, eds., 2005) [hereinafter Barry \& Eckersley]. See also Rethinking the GreEn State: EnVIRONMENTAL GOVERNANCE TOWARDS ClimATE AND SuSTAINABILITY TRANSITIONS (Karin Bäckstrand \& Annica Kronsell, eds., 2015). These works examine the notion of "eco-state" (or, in the case of the second one, "green state") in ways substantially different from the concept I am developing in my work. Both concentrate mainly on enhancing environmental-protection efforts within existing states. For instance, introductory comments in the book edited by Barry and Eckersley note that it aims to explore "to what extent it might be possible to 'reinstate the state' as a facilitator of progressive environmental change rather than environmental destruction ...." See supra Barry \& Eckersley, at $\mathrm{x}$. 
of nationalism.

\section{IIA. Nationalism and Its Dark Side}

In an excellent book dating from the year 2000, Michael Hechter examines the nature and behavior of nationalism. ${ }^{291}$ In doing so, he offers a clear definition of "nation" and of "nationalism"-while acknowledging the difficulty of doing so-and he addresses three particular issues. ${ }^{292}$ First, why is nationalism a recent phenomenon, dating back only for two or three centuries? ${ }^{293}$ Second, why does nationalism emerge differently in different circumstances - that is, strong and insistent in some, much less so (or not at all) in others? ${ }^{294}$ Third, how can the "dark side" of nationalism - that is, its tendency toward violence — be contained? (This third question provides the title for his book: Containing Nationalism) ${ }^{295}$

\section{IIA1. Defining Nationalism and Its Relatives}

Each of these three questions bears on our inquiry here, which focuses especially on sovereignty, authority, and governance. After all, the desire for some form of self-rule or at least a high degree of self-determination or self-governance, lies at the center of Hechter's definition of nationalism. He asserts that "nationalism" (a term he says first appeared in 1774) ${ }^{296}$ means "collective action designed to render the boundaries of the nation congruent with those of its governance unit."297

Naturally, that definition requires further definitions, particularly of "nation" and "governance unit." Hechter urges that although "the terms 'nation' and 'state' are often used interchangeably, ... nationalism cannot be understood when the meanings of these two terms are not kept distinct." 298 Tracing the word "nation" to the Latin verb nasci (to be born), Hechter explains that "the term 'nation' originally designated a group of people who were born in the same place." 299 More recently, though, a broad consensus has emerged as to what "nation" means in today's world: "Whatever else it may consist of, the term nation refers to a relatively large

\footnotetext{
291. See generally Michael Hechter, ContAining NATIONAliSm (2000).

292. See discussion infra Section IIA1.

293. See id.

294. See id.

295. See discussion infra Section IIA2.

296. HECHTER, supra note 291, at 5.

297. Id. at 7 .

298. Id. at 11.

299. Id. at 10 .
} 
group of genetically unrelated people with high solidarity." 300

As for "governance unit," Hechter refers to "that territorial unit which is responsible for providing the bulk of social order and other collective grounds-including protection from confiscation, justice and welfare-to its members." ${ }^{301}$ He emphasizes that although many governance units in today's world are states, this has not always been true (he reminds us that "in classic feudalism the mantle of governance falls to the manor"), ${ }^{302}$ and it is only partially true even now.

It is at this juncture that Hechter first emphasizes the significance of federal systems. Noting first that in a few countries, such as France, the governance unit is the central state (so that the content and schedule of public-school instruction in France, for instance, is highly uniform on any given day), this is in fact the exception:

In many other complex societies, however, governance tasks are carried out simultaneously in different territorial units. Since governance in federal systems always involves more than one level of decision-making, its locus is much more difficult to ascertain. In the United States, for example, the Federal government is responsible for the provision of defence and, ultimately, of justice. But state governments are responsible for providing some collective goods (including higher education, freeway maintenance, and aid to dependent children), whereas still others (including policing, fire protection and elementary education) are the responsibility of municipalities, or even smaller units such as local school districts. Since the allocation of powers between various levels of government has always engendered intense political conflict, it is no easy task to determine where the bulk of governance occurs in a polity like the United States. ${ }^{303}$

With these specific definitions of "nation" and "governance unit," and particularly with the suggestion that it is often difficult in federal systems to determine precisely what is the "governance unit" (the upper level of the federal government? a lower level?), it is not unusual for nationalism to emerge in such federal systems. This is an important point in my examination of the mechanisms that might be used at the international level to ensure global agroecological integrity. After all, the international legal system in place since World War II is to some degree a federal system in which some rules and functions - peace-keeping, for instance, and some

300. Id. at 11. Since all humans are in fact genetically related, Hechter must be regarded as referring to people not from the same family of recognized kinship. In support of his definition, Hechter cites John Stuart Mill, Max Weber, Josef Stalin, and numerous others who emphasize the same elements. Id.

301. Id. at 9 .

302. Id.

303. Id. at 10 . 
elements of economic management - are collectivized in international organizations that have nearly universal membership by states. In those respects, then, at least the intended "governance unit" is a federal one with many powers remaining with states but a few powers delegated broadly to the purview of one or more international organizations.

\section{IIA2. Containing Nationalism}

This being the case, Hechter's views on nationalism — and particularly his third question about how to "contain the dark side" of nationalism (bringing discord and violence) - hold direct relevance to any effort to design a system that is more effective than the current one is at providing urgently-needed protections of the ecosphere. What does Hechter regard as the best method for gaining broad support for a centralization of certain key public goods? He offers this answer:

The best hope for containing the destructive elements of nationalism therefore hinges on conditions that decrease the demand for sovereignty among national groups. Such groups demand sovereignty to enact a governance structure that is more accountable to them. Whereas distinctive national values will tend to persist, the responsiveness of central states to these distinctive values can be affected by institutional arrangements that, at least in principle, are modifiable. ... [I]nstitutions which increase the central state's accountability to national minorities should reduce the demand for sovereignty, and hence the potential for nationalist conflict. ${ }^{304}$

Hechter then explains that "[w]ould-be institutional designers have several prominent ideas to consider on this score: [1] consociationalism, [2] electoral laws, and [3] that variant of indirect rule known as federation." ${ }^{05} \mathrm{He}$ deals quickly with "consociationalism," in which "leaders of the various nations participate in decision-making as a cartel," with each leader "armed with veto powers." 306 Such a system, which Hechter says has prevailed (and gained praise) in Switzerland, attracts criticism on grounds that (i) the veto power "is a recipe for governmental inaction," (ii) "it avoids popular participation," in part because (iii) "it relies on élite bargaining carried out in secrecy."307

Electoral laws, Hechter explains, can overcome some of consociationalism's deficiencies, but they introduce more of their own

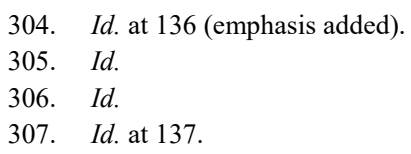


shortcomings. ${ }^{308}$ By "electoral laws," or what he more precisely calls an "electoral system," Hechter means a system that "translate[s] electoral votes" by the public directly "into parliamentary seats" and thereby assures that "representatives are held accountable by [their] constituents." 309 Whatever other merits such a system may have, Hechter says, it "may not necessarily reduce intergroup conflict" 310 - that is, it does little to suppress the "dark side" of nationalism.

Hechter then turns his attention to "that form of indirect rule known as federation" or what is also commonly called federalism:

Federation is an institutional arrangement, taking the form of a sovereign state, that is distinguished from other such states solely by the fact that its central government incorporates regional units into its decision procedure on some constitutionally entrenched basis. . . . Federations all employ indirect rule, but their forms can vary widely. For example, the degree to which federal units are formally equal is always an empirical question (in the United States, for example, the Rhode Island voter for the Senate has twenty times the power that her California counterpart has). Further, federations have different degrees and types of decentralization. ${ }^{311}$

Nothing about Hechter's definition, of course, is surprising. Most readers will be familiar with federalism. What warrants attention, however, in Hechter's assessment is this: Federalism can, he says, both (i) intensify nationalist conflict and (ii) inhibit nationalist conflict. ${ }^{312}$ Federalism might stimulate nationalist conflict, Hechter explains, "because it provides potential nationalist leaders with patronage and other resources that can be mobilized for nationalist ends." 313 Beyond that, federalism "may have cognitive implications": when a group is treated as a subsidiary unit of a larger, federal political entity, that group is encouraged "to think and act according to national categories," thereby regarding itself as having a distinct (national) identity. ${ }^{314}$ As evidence of federalism's tendency to stimulate nationalist conflict, Hechter cites the U.S.A. (the "Civil War broke out in a federation"), Pakistan (which, in its early days as a federation, "lost Bangladesh"), and the three main "socialist states to dissolve following the climactic year of 1989," namely the Soviet

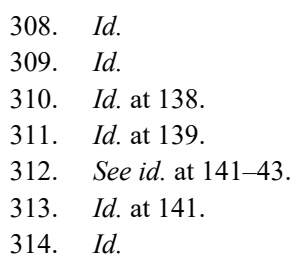


Union, Czechoslovakia, and Yugoslavia — all of which "also just happened to be federations." 315

On the other hand, federalism can inhibit nationalist conflict. After all, federalism "involves the devolution of (at least some) decision-making to localities" thereby "increas[ing] local self-governance" on the part of the federation's constituent political units and reducing each one's "demand for sovereignty." 316 The implications of this reasoning, Hechter says, are clear:

A constitution that minimizes the [federal] state's control over disposable, transferable revenue and rights presents a very small target for nationalists. It stands to reason that local politicians are less likely to play the nationalist card when their constituents see less benefit in [local] sovereignty. [Accordingly,] to contain nationalism, the central rules of multinational states ought to grant political devolution to mobilized national minorities. ${ }^{317}$

As evidence of how federalism can inhibit nationalist conflict, Hechter cites several illustrations. One is "Britain's [late-1990s] offer of devolution to Scotland and Wales..., with the more thoroughgoing devolution in Scotland more enthusiastically supported than its relatively anaemic Welsh counterpart." ${ }^{118}$ Other illustrations appear, Hechter reports, in "Spain and Belgium [which] have recently undergone significant constitutional moves from unity toward federation as a means of resolving national conflicts." 319 And "even France - traditionally, the archetypal unitary state-has granted Corsica a certain amount of devolution." 320 In each of these and other cases that Hechter cites, "very significant powers have been granted to the relevant subunits" within the large federated state. ${ }^{321}$ As discussed above in Section IC2 of this Article, these instances of devolution can be seen as fitting within a larger landscape of constitutional and structural options that reveal a creative and sophisticated approach to political-governance arrangements.

In sum, Hechter draws attention to two opposing views. One posits that federalism tends to intensify nationalist conflict. The other posits that federalism tends to inhibit nationalist conflict. He explains several factors

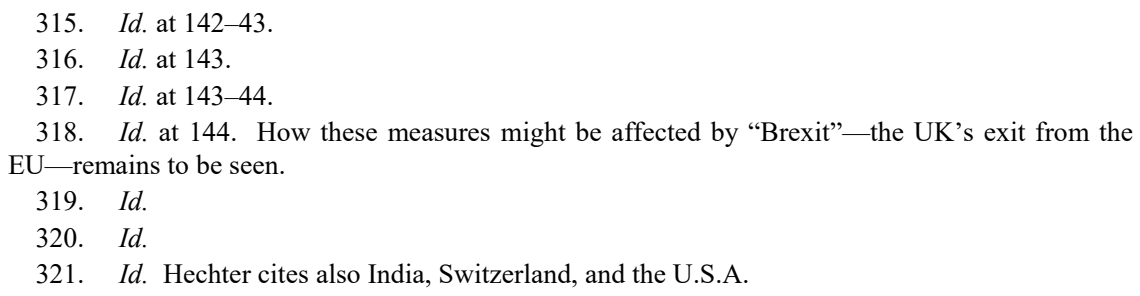


that might help explain this apparent inconsistency, ${ }^{322}$ and then concludes by asserting that federalism works best (in the sense that the violence it engenders remains weakest) when a proper balance is struck between centralization and decentralization:

To contain nationalistic violence, therefore, a balance must be struck between peripheral regions' dependence on the centre for military and economic resources, and the autonomy to pursue their own production and consumption values. Federation is no panacea for nationalist violence in relatively centralized states, but it does offer substantial hope for mitigating nationalism's dark side. ${ }^{323}$

Hechter acknowledges that striking this correct balance "is much less difficult to prescribe than to implement." ${ }^{324}$ This is true, but it need not be overly dispiriting. Hechter's analysis suggests that federalism is workable; the rewards are potentially quite high if the proper balance of authorities can be struck between the central unit of governance and the peripheral units of governance. While Hechter's analysis concentrates on states and their subsidiary units, it offers a useful prospect also for interstate relations as well. If the correct balance of authorities can be struck between (i) centralized functions at the international level (as with use-offorce rules and certain economic-management rules of the sort referred to above in Figure 2, near the beginning of this Article and (ii) decentralized functions at the "lower" levels of the region, the state, the district, and the local units of government, then perhaps what Hechter calls the "nationalism's dark side" can be contained at the global level.

Hechter goes on to enumerate some especially important elements in "implementing decentralization" properly - that is, in ensuring a correct balance between the central and the peripheral authorities in a federal system. ${ }^{325}$ One such element is procedural justice: "When people think that a particular decision is unfair, but that the procedure that generated the decision was fair, they are less likely to act on that perception to change the outcome. Procedures perceived as fair can significantly influence perceptions of the fairness of a specific outcome." 326 Moreover, Hechter

\footnotetext{
322. For instance, Hechter cites some recent evidence that explores (i) the influence that economic development has on the incidence of rebellion and protest in federal systems, (ii) the difference between states that have at least one minority concentrated in a region with its own governance structure versus those states to do not, and (iii) the distinction between rebellion (aimed at secession) and protest (aimed at lesser degrees of reform). Id. at 146-48.

323. Id. at 152 .

324. Id.

325. Id. at $152-53$.

326. Id. at 153 .
} 
writes, procedures are regarded as fair if they entail adequate checks and balances, provide ample "voice" by various stakeholders in the decisionmaking process, and seem to be neutral, accurate, transparent, and thorough in their application. ${ }^{327}$

In addition to procedural justice, though, Hechter emphasizes that minority cultural protections are also essential to implementing decentralization in a system. ${ }^{328}$ He insists that " $[\mathrm{t}]$ he best means of instituting minority cultural protectionism is by making the, admittedly, counterintuitive, claim that the majority will profit from it." 329 The most persuasive way of making this claim is to explain "that peripheral autonomy is desirable simply because it preserves cultural diversity." 330 He likens cultural diversity's benefits to biodiversity's benefits: "Like biodiversity, cultural diversity may result in future social pay-offs that are impossible to foresee." 331 He acknowledges how strong the argument seems that cultural diversity "threatens political unity and social order," but says that this argument "is quite mistaken: order can be provided more efficiently in a society made up of different national groups, each having distinct values, than in a culturally homogeneous society"-mainly because "a viable central state can profit from the social control activities of its constituent national groups." 332

Let me sum up: Hechter lays out a set of key points about nationalism. First, he defines nationalism as "collective action designed to render the boundaries of the nation congruent with those of its governance unit" and explains that the urge for collective action (nationalism) is a recent phenomenon emerging from peculiarities of European history. Second, nationalism manifests itself differently in different political and cultural settings, and this complicates the effort to contain the "dark side" of nationalism - that is, its tendency toward serious discontent and violence against central authorities that a particular nationality thinks are infringing on their own self-determination. Third, although a variety of methods have been tried in order to prevent such discontent and violence, federalism holds the most promise for doing so. Fourth, federalism will not work unless it is carefully designed to strike a proper balance between the central and the peripheral authorities. And fifth, striking that proper

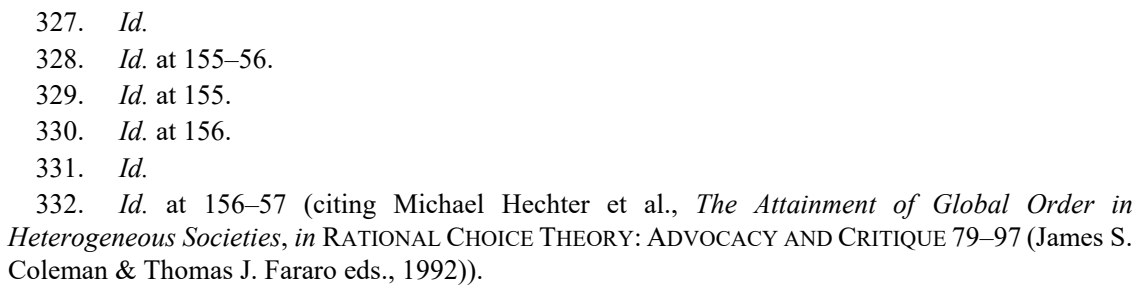


balance turns on such factors as procedural fairness and special protection of minority interests - that is, the interests of that "nation" or group that considers itself somehow separate in character from the larger population that the federal system encompasses.

In the closing two pages of his book, Hechter offers a last reflection. Having explored nationalism and how to contain its "dark side," Hechter speculates on the future of nationalism and of the "collective action" that defines it. In particular, he suggests that a different basis for collective action might at some point displace nationalism:

Although it is unlikely that nationalism will subside in the future, there is no reason to believe that it will be the most salient form of political conflict indefinitely. ... [Recall that] there ha[s] been a marked increase in direct rule - that is, in political centralization ... [ [and that this has resulted importantly from the] development of the welfare state during the post-war era in Western Europe and Canada .... By extending a wide range of entitlements, the welfare state increased citizens' dependence on the central state at the expense of local authorities. . .

[This might all change. We] ought not be too surprised if class supersedes ethnicity as a basis of collective action sometime in the future. Under what conditions might this reversal come to pass? One possibility leaps to mind. To the degree that alternative sources of welfare dry up, then organizations based on social class may be expected to return to the fore. The gradual demise of the welfare state in the United States may revive class politics in its wake. ${ }^{333}$

Hechter's closing speculations add a new wrinkle to our consideration of nationalism: not only has it manifest itself differently in different settings, and not only does it present a "dark side" that needs to be suppressed, perhaps through a carefully-designed form of federalism. In addition, economic and political developments might cause nationalism to be supplanted by class as the more potent force to be dealt with in maintaining order in the world. If this were to occur, then it would seem to require us to be even more imaginative in designing a form of federalism that would reflect the two key elements Hechter emphasized: procedural fairness and special protection of minority interests.

Let us turn our attention from nationalism to nationality. Specifically, how does nationality differ as a historical, ideological, and even emotional matter from some related concepts?

333. Id. at $158-59$ (emphasis added). 


\section{IIB. Nation, Country, Patria, State}

For a synopsis of how best to distinguish (maybe "disentangle" is more apt) the meanings of these four terms - nation, country, patria, and state-I turn to an elegant account written in the 1960s by Alexander Passerin d'Entrèves of the University of Turin. ${ }^{334}$ For d'Entrèves, a crucial starting-point in understanding these terms and the concepts they convey is to realize (i) that they have changed dramatically over time, and that (ii) these changes have resulted in large part from the intentional actions of strong political leaders.

On the first of these points, d'Entrèves explains that "[ $t]$ he ideas of nation and nationality are entirely absent from the definitions of the State which can be found in the writings of the three great thinkers who first mapped out the new landscape of the modern political world"335 — namely Machiavelli, Bodin, and Hobbes - and in fact "the concepts of nation and nationality are a comparatively recent product of history." 336 This is not to say that $n o$ sense of national differences was present in Europe at or before the times of those writers (the early 1500s for Machiavelli, the latter 1500 s for Bodin, and the mid-1600s for Hobbes), but the national differences that were perceived then "did not lead ... to a denial of a higher unity, that of the respublica christiana"; instead, "such diversities were thought of as the natural differences within a large family." 337 An example that d'Entrèves cites involves Dante, whose writings (in the early 1300s) show the separation between the two concepts of state and nation:

No one could possibly deny that Dante had a very strong national feeling. Italy stands out in his vision as a well-defined unit, with features, a language, a heritage of her own. But all his love for Italy did not prevent Dante from championing a supranational political programme: the unity of the Empire, in which he was content to reserve for his country merely a privileged place. ${ }^{338}$

On the other hand, d'Entrèves explains that there were efforts by political leaders - especially by the "new princes" at the beginning of the

334. Alexander Passerin d’Entrèves, The Notion of the State: An Introduction to POLITICAL THEORY (1967). The author explains that the book was first published in Italian in 1962. Id. at vii.

335. Id. at 170.

336. Id. at 171

337. Id. at 172

338. Id. Both Dante and Machiavelli, d'Entrèves continues, "seem to conceive the bond of nationality as something quite distinct from, perhaps even irrelevant to, the bond of citizenship, the political bond." Id. 
modern era (the sixteenth century, in his view) — "to make advantageous use of national consciousness ... [and] to mould and to direct that consciousness to the pursuit of certain peculiar ends," especially to consolidate power. ${ }^{339}$ Indeed, this is d'Entrèves's second main point: the rise of a concept of nationality in Europe resulted in large part from the intentional actions by strong and ambitious political leaders.

For instance, d'Entrèves asserts that the famous lines from Shakespeare's Richard II referring to "[t]his blessed plot, this earth, this realm, this England" expresses a strong sense of English nationality that "found both a pattern and a stimulus in the exceptional personality of that typical 'new prince', the great Elizabeth I," whom d'Entrèves calls a "master in the art of channeling the growing nationalism of her subjects within the range of her crude power-politics." 340

A question then emerges: If Elizabeth I and other leaders around the time of Bodin and Hobbes were using the concept of the nation as d'Entrèves asserts, why would d'Entrèves also insist that those writers did not include the concept in their definitions of the state? The answer, d'Entrèves explains, lies in the difference between ambition and description:

[Although it might] seem rather puzzling that writers, such as Machiavelli, Bodin, and Hobbes, should have passed over in silence so important an element as nationality in their definition of the State, ... the puzzle can be explained when we remember that the convergence of State and nation, which had at least in part taken place in their days, was closely tied to the pursuit of a particular programme, and ultimately depended on the 'will to power' of the new princes and the new States. Any change in that programme, and the two concepts could again fall apart. This is what actually happened when from national unification the rulers of Europe embarked on territorial expansion and on power-politics pure and simple. New ideologies [that is, ideologies other than that of nationality] were called upon to provide justification of the State's new course. $^{341}$

What d'Entrèves is describing, therefore, is nationality as a sort of flash in the pan, a concept that (i) sizzled loudly when political leaders (the European "princes," in his terminology) found advantage in nurturing it in order to strengthen the powers of the state but then (ii) got suppressed when political circumstances shifted. "Paradoxically, the idea of nationality seems to suffer eclipse at the very moment when the modern

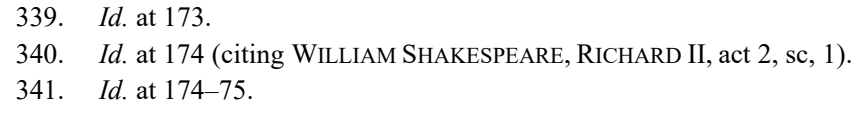


State was coming of age and the map of Europe was taking its familiar shape. Eighteenth-century statesmen neatly severed the practice of politics from nationalistic emotions." 342

It is at this point in his account that d'Entrèves introduces the notions of "country" and "patria." 343 In order to explain how the idea of the nation was manipulated for political purposes by the European "princes" in hopes of securing some political legitimation for the state, d'Entrèves distinguishes four terms - nationalism, nationality, country, and patriain a succinct way:

Nationalism transformed nationality from an historical fact into a political ideology, into the one exclusive principle of legitimation of the State. In order to do so it was necessary to affirm not only that nations existed as separate and well-determined units, but that national unity was an ideal to be sought after and fostered, and that the only 'good' State was the Nation-state. Thus was the nation raised to a dignity it had never possessed in the past, or rather to a dignity which had been given a name in past ages, whenever there was a question of locating the ultimate focus of allegiance and loyalty, the highest good for which men could be called upon to sacrifice their life. The Romans had called it patria. The nearest equivalent in English is, I believe, not so much 'fatherland' as 'country'....

[T] he idea of country has a long history and a respectable pedigree. Patria is an inheritance from classical culture. It is held out as the highest object of love in a number of famous writings which like Cicero's De Officiis, provided the mainstay of education in the West. Patriotism existed long before there were nations, let alone Nation-states. [Moreover,] patriotism was not necessarily linked to national consciousness or to political allegiance. ${ }^{344}$

In no way, d'Entrèves insists, was it a foregone conclusion that what he calls "the ultimate focus of allegiance and loyalty" would be the nation. ${ }^{345}$ Instead, the "ultimate focus" has shifted over time and been different for different people. True, for some persons the highest allegiance might be to one's nation, as defined by some confluence of language, history, religion, ethnicity, homeland, and the like. For others, though, it would be a personal loyalty to a king; for yet others, it would be an allegiance to a particular city-as for Machiavelli to Florence, d'Entrèves writes. ${ }^{346}$ For many men, he insists, "the ideas of State, nation,

\footnotetext{
342. Id. at 175 .

343. Id. at $176-77$.

344. Id.

345. Id.

346. Id. at 177.
} 
and country in no sense coincide." 347 For Voltaire, d'Entrèves points out, "one's country is wherever one lives happily and well [ubi bene, ibi patria]" 348 - which amounts to the same thing as saying that the "country" or "patria" to which a person feels allegiance "is the result of a choice."

Having introduced this idea of ubi bene, ibi patria - that a person chooses where his or her loyalty and allegiance lie, based on where he or she lives happily and well-d'Entrèves emphasizes how the French Revolution illustrates how it is possible for there to be in fact a convergence of nation, state, and country.

[W]e shall never appreciate the tremendous importance of the French Revolution unless we realize that it was that revolution which gave the concept of nation an entirely new meaning, transforming it, as it were, from a mere product of history into a deliberate construction, a partnership not only of mores but of wills. This is the time when we witness the final coincidence of the three ideas we have followed throughout their erratic independent course. 'The nation becomes the country,' but it does so because the nation is the expression of selfdetermination, because the State no longer consists in the mere whim of the autocrat or in the consolidation of the interests of a few privileged classes, but in the sovereignty of the 'general will'.... [Rousseau, so influential in the French Revolution,] was the prophet of the new religion which was henceforth to dominate the modern world ... [in saying that patriotism] is the true way to salvation. ... [In this view,] Democracy joins hands with Nationalism, and the State, hitherto the sum of cold calculations of power, gathers to itself a power hitherto unknown. For that power is no less than the outcome of a whole people's participation in those decisions which were at one time the privilege of the few. ${ }^{349}$

The French Revolution, then, provided the peculiar political and social setting that brought unity to the three concepts - that is, the state as a package of political power and authority, the nation as a partly-real but partly-contrived social construct, ${ }^{350}$ and the country or patria as the object of a person's highest loyalty and allegiance. This unity, d'Entrèves reminds us, was short-lived, so that "there was soon once again to be a parting of the ways [between state, nation, and country] in this new

\footnotetext{
347. Id.

348. Id. at 178 ("Where it is good, that is my fatherland.").

349. Id. at $178-79$.

350. Id. In another passage, d'Entrèves reflects this partly real but partly contrived character of the nation by highlighting "two possible ways of conceiving the nation: one based on purely "natural' factors, the other on 'spiritual' elements; the one on something give, the other on something desired." The first of these conceptions, he explains, focuses on some fairly straightforward "linguistic and ethnical differentiation" as well as more "dubious biological factors, blood and race," whereas the second conception "was based on the recognition of the importance of the cultural bond" among people claiming to be part of the same nation. $I d$. at $179-80$.
} 
world." "351 According to d'Entrèves, this parting of the ways reflected the dramatic differences that occurred in how various states and nations developed in Europe. ${ }^{352}$ I would emphasize a different reason: the dramatic differences in how various states and nations outside Europe developed, and particularly how some states that were only recently decolonized when d'Entrèves wrote his book (in the 1960s) have surged in importance on today's world stage.

I find d'Entrèves's account of these related concepts - state, nation, country, patria - directly relevant to my principal aim in this Article. That aim is (i) to emphasize how poorly certain concepts rooted in sixteenthand seventeenth-century Europe serve the needs of today's world and (ii) to outline how they might be modernized to make them suitable for use in addressing global problems. What d'Entrèves's account offers is an explanation of why the concept of nationality cannot be relied on to convey much legal significance today. Despite the enthusiasm with which some leaders of various countries or groupings tout the significance and the value of nationality, even a brief historical survey reveals that "nation" and "nationality"- like "sovereignty" - are terms that defy clear definition at any one point in time, much less over a chaotic history. They reflect historical realities that passed away long ago and that in any event were largely ignominious in their origin (efforts by princes to consolidate their power)..$^{353}$

In closing his survey of these terms and their meanings, d'Entrèves offers a look to the future. After highlighting the fact that the modern state has drawn on the concept of the nation for legitimacy-hence the term "nation-state" - d'Entrèves surmises that whatever fundamental political unit emerges in the future will likewise need to find some legitimizing concept to lean on for support:

We often hear it said that the new, the supra-national State, which is invoked and longed for today by so many, will be the signal for the final disappearance of those nationalisms which have brought Europe to the brink of ruin [he refers surely to the two World Wars, both commencing on the European continent]. But one thing at least can be said with certainty. Whenever the new [form of] State arises and establishes itself as a working proposition, it too will need an 'ideology' on which to lean, a faith capable of kindling men's imagination and warming their hearts. It will be essential, in other words, for this State to inspire men with a spirit of dedication as great as that inspired by the 'old' State, and for it

\footnotetext{
351. Id. at 179.

352. Id.

353. See supra note 339 and accompanying text.
} 
to acquire in the eyes of its new citizens the value of a new and better communis patria. ${ }^{354}$

As I have suggested in my 2017 book, ${ }^{355}$ a possible legitimizing concept for a new form of political organization - what I refer to as the "eco-state"-is "ecospheric natural law."

IIC. Further Clarity on the Nation-State: Ali Khan and Patrick Glenn

In the preceding Section, I drew on the writings of Alexander Passerin d'Entrèves in the 1960s to highlight how the concept of the nation (like the concept of sovereignty) is hard to define, changeable over time, and only sporadically and opportunistically associated with the concept of the state. Similar points have been emphasized in more recent writings. In the following paragraphs I draw attention to the writings of two persons whom I count among my friends. Like d'Entrèves, they both explore the historical foundations of the so-called nation-state, and they counsel against perceiving of it as in any way permanent — or perhaps even present today in the real world.

\section{IIC1. Accidents of the Past, Diversity of the Future}

In a book published about twenty years ago, L. Ali Khan offers an elegant historical account of the state and the sovereignty it came to exercise. He places special emphasis on the peculiar and accidental influences - including the foibles and fates of certain individual personsthat contributed to the victory that political and religious pluralism enjoyed in Europe in "dismantl[ing] the authority of the medieval legal order that sought to impose, without consultation, one set of values and one set of ruling elites [- that is, the values and elites of the Church-] on all communities" in that part of the world. ${ }^{356}$ Urging that we regard the concept of the state as a product of those peculiar and accidental influences, Ali Khan explains that it should be recognized as "the most serious impediment to the creation of a global household" that is already under way, haltingly, as a "complex process of enmeshment" among the

\footnotetext{
354. D'ENTRÈVES, supra note 334, at 180.

355. See HEAD-2017, supra note 4, at 386-90.

356. L. Ali Khan, The Extinction of Nation-States: A World Without Borders 2 (1996). Ali Khan, a legal scholar and professor at Washburn University School of Law, is a recognized expert on international and comparative law, with specializations in international terrorism and Islamic law.
} 
world's diverse communities. ${ }^{357}$ By prevailing over that impediment, Ali Khan asserts, we can facilitate the emergence of what he calls "Free State," at which time sovereign borders will "evolve into open borders, allowing the free flow of goods, services, capital, labor and persons" and "the nation-state loses its identity as a distinct legal entity." 358

Terms and ideas of this sort-"global household," "enmeshment" of communities around the world, "Free State," and the like - might strike a casual reader as overly imaginative or ethereal, not to mention unlikely in today's world. Ali Khan addresses that point in two ways. First, he acknowledges that this "Free State" condition is not one that is likely to be attained soon, given the fact that in today's world "many nation-states are powerful and many people do not envision beyond their national boundaries." ${ }^{359}$ Second, he urges the reader to realize that "the Grotian concept of the sovereign state was essentially idealistic at the time" that Grotius struggled to design a system that could effectively supplant the then-dysfunctional and anachronistic political system that despite its apparent permanence and unshakeable supremacy was in fact experiencing its death-rattle in the Thirty Years War. ${ }^{360}$ Expressed in an oversimplified way: what might seem utterly impracticable today will surely change, and it is in fact quite rational to try anticipating and shaping such change. Indeed, perhaps we have a duty to do so in light of such pressing environmental dangers as those posed by global climate change and soil degradation.

Ali Khan's account of the historical formation of the sovereign state begins with a synopsis of how the protracted effort following the fall of the Western Roman Empire to re-establish "one superpower over diverse communities" gained traction, encountered barricades, and ultimately collapsed in failure. ${ }^{361}$ Here is how he characterizes that sweep of history and then applies its lessons to the future:

The historical events that furnished the essential ingredients for the formation of the sovereign state involve the era of empires when imperialism clashed with the universal church, a fierce struggle leading

\footnotetext{
357. Id. at 3 .

358. Id. at 8 .

359. Id. at 9 .

360. Id. at $1-2$.

361. Id. at 13. He identifies, for instance, the specific roles played by German emperors and Roman popes, by competing conceptions of law ("one derived from the power of material resources, including weapons, and the other from the authority of theology including morals"), by Muslim Turks, by Martin Luther, and by the colonial adventures of the French, the English, the Dutch, and the Spaniards - culminating, then in the 1648 Peace of Westphalia, which ended the Thirty Years War by "restructur[ing] the genetic composition of the Holy Roman Empire, vesting its principalities with a degree of autonomy and legally freeing them from both papal and imperial institutions." Id. at 14-15.
} 
to their mutual attrition. The eventual triumph of the sovereign state over mighty empires and universal religions is a story of the human will to resist the authority of a single superpower, striving to rule all communities in every corner of the world, sometimes in the name of One Emperor and sometimes in the name of One God. It reminds us that no single people or church can control the destiny of the world. Nor can the social, moral and spiritual development of humanity ever be uniform. Diversity, not uniformity, is the driving motif of the human story. Thus the rise of the sovereign state reveals a simple historical secret: any attempt to impede the flowering of diversity is doomed to fail. Even when sovereign states seek to mutate into Free States - a central theme of this book - the human desire to create and preserve culturally divergent communities will continue to thrive. A single world government is, therefore, not a new vision of future society; it is a failed medieval dream to be avoided. ${ }^{362}$

In short, Ali Khan (i) describes how the sovereign state arose out of peculiar historical circumstances, (ii) emphasizes the significance of diversity over uniformity as "the driving motif of the human story," and (iii) projects a global political future in which that same drive for diversity will continue to prevail, auguring against any singular world government. ${ }^{363}$

\section{IIC2. No Such Thing as a Nation-State?}

My late friend Patrick Glenn, formerly at McGill University, uses the same starting-point: diversity. In particular, he has explained that there is a strong element of artificiality in the theory that the states in today's world are "national" in character - that is, that they comprise or reflect a single "nationality." In a book published shortly before his death, Glenn emphasized the fact that there is not, and never has been, such a thing as a "nation-state." 364 Instead, all states are "cosmopolitan" in character.

[My] argument is that all states are cosmopolitan in character, often in spite of themselves and of the choices they may have made. Most people do not presently think that this is the case ... but this is principally because the western theory of states has been formulated in terms of necessary equality and uniformity within states. It is the notion of a "nation-state" that has largely prevailed. ...

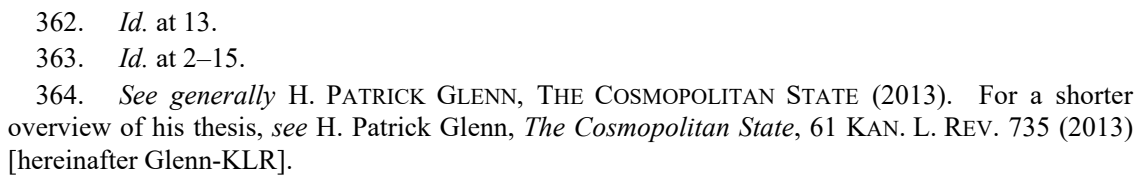


[That notion] began as an essentially romantic idea in eighteenth century France - the idea that "la nation" should have its own legal and political structures ... [but it] is an idea that has failed. We have been trying to make it succeed for over two centuries now, but it has not succeeded. It is simply not the case that there has ever been a nationstate, and we may now therefore draw the conclusion that there never will be. ${ }^{365}$

Glenn explains that he is using the term "nation" according to the usual definition implying a homogeneous people. ${ }^{366}$ This definition suggests that in order "to have a 'nation-state' which is in fact true to this bringing together - this confluence of the institutions of both a state and a peopleyou have to find a nation that satisfies the requirement of homogeneity, and it must coincide with a given state structure." $" 367$ It is impossible, Glenn asserts, to find such a nation-state. Some of the seemingly obvious candidates - he mentions Finland, Germany, Japan, and North Korea-all fail to meet the homogeneity test. ${ }^{368}$ Even such a small state as Tuvalu, which might be thought to have a congruence of a nation and a state, fails that test: Tuvalu "is ethnically, religiously, and linguistically diverse."369

Concluding, therefore, that there is no such thing as a nation-state, Glenn proceeds to an even more interesting assertion: "The most successful states, moreover, are the states that have been most successful in dealing with their own internal diversity." ${ }^{370}$ Citing the U.S.A. in particular, Glenn offers these observations:

There is no nation here, in the sense of a homogeneous population. The United States is a successful cosmopolitan state because its legal and political project has succeeded - most of the time on most questions - in having the people here think in terms of what has been called "constitutional patriotism".... Civic identity thus largely prevails over other identities. There is collaboration in working with diverse peoples. So the states that have been seen as the most successful republican and united enterprises are in a sense paradoxically the states that have been most successful in dealing with their inherently cosmopolitan character. ${ }^{371}$

365. Glenn-KLR, supra note 364, at 737-38 (emphasis added).

366. Glenn refers to "a homogeneous people united by language, religion, and even ethnicity." Id. at 738. As noted above, d'Entrèves refers to a "fairly straightforward linguistic and ethnical differentiation as well as more dubious biological factors, blood and race" as elements in defining a nation. See supra note 350. The formulation that I used above near the end of Section IIB was "some confluence of language, history, religion, ethnicity, homeland, and the like."

367. Glenn-KLR, supra note 364, at 738 (emphasis added).

368. Id. at $738-40$.

369. Id. at 740 .

370. Id. at 741 (emphasis added).

371. Id. 
What does Glenn mean by the term "cosmopolitan"? He takes great pains to distinguish that term from the term "universalist":

[O]ne can be cosmopolitan without being universalist in character .... For this I rely on what I take to be the usual meaning of "cosmopolitan," which the Oxford English Dictionary defines as "[h]aving the characteristics which arise from, or are suited to, a range over many different countries." This ordinary language understanding of cosmopolitanism has been defended with great subtlety by Stephen Toulmin, who in the mid-twentieth century argued that "cosmopolitan" means what the word indicates - it is a combination of "cosmos," hence "cosmo," and "polis," or polity - so that "cosmopolitan" means it is possible to have a harmonious bringing together of the cosmos and a particular polity. This understanding of the world implies a notion of harmonious coexistence rather than of obligatory universality.

Given this ordinary language understanding of cosmopolitanism, the cosmopolitan state is not a state of domination that purports to impose its law on the rest of the world. It is not a world state or a hegemonic state. Instead, the cosmopolitan state is a state that has dealt more or less successfully with the inevitable internal and external diversity within which all states must function. There is no cosmopolitan universal law, but there are cosmopolitan attitudes and cosmopolitan methods. There are also cosmopolitan officials who know, in light of the utter particularity of each state, how to reconcile in a particular state claims for exception to and application of the law and normativity of the majority In short, the cosmopolitan state has to address the challenge of balance. $^{372}$

This notion of cosmopolitanism is precisely what I believe should lie at the heart of the pluralistic sovereignty that I have introduced briefly at the end of Part I of this Article. The same notion should influence the striking of a balance in federalism that I described above. ${ }^{373}$ I would take issue with Glenn, however, in his assertion that there "is no cosmopolitan universal law." ${ }^{374}$ What will be necessary in order to assure agroecological integrity - the subject of my overarching research effort-is a broad acceptance of the proposition that some fundamental propositions, comprising what I mentioned above as "ecospheric natural law," are universal in character, similar in character to norms of jus cogens as recognized in contemporary international law. ${ }^{375}$

372. Id. at 742-43 (emphasis added) (internal citations omitted).

373. See supra text immediately following note 332 (urging that "federalism won't work unless it is carefully designed to strike a proper balance between the central and the peripheral authorities").

374. Glenn-KLR, supra note 364 , at 743.

375. The notion of jus cogens, as reflected in Article 53 of the Vienna Convention on the Law of Treaties, is that of a "peremptory norm of general international law," which the provision then 
Not content with just issuing general prescriptions-for instance, insisting that a successful cosmopolitan state is one that creates "a harmonious bringing together of the cosmos and a particular polity," and urging that "the cosmopolitan state has to address the challenge of balance" 376 - Glenn offers a fresh conceptual perspective on how to achieve such a "bringing together" and such a "balance." He draws from Hilary Lawson's 2001 book Closure: A Story of Everything: ${ }^{377}$

Lawson says two things. The first is that the only way we can understand the world is to effect some kind of closure. If you want to do anything, if you want to think about anything, you must narrow the focus. You've got to decide that this is your problem, this is your unit of political construction, this is your legal problem, or whatever it might be... Once you've effected a closure around a problem, concept, or thing, then it becomes possible to study it.

This is an interesting proposition. The more important and second part of Lawson's project, however, is to say that closures can never be definitive. Closures can never be definitive because when effecting closure, you necessarily effect a closure around something that is part of a much larger field of what Lawson calls "texture." You are faced constantly with a reality of undistinguished texture. To understand anything about that reality, you must effect a kind of closure. But the closure effect is surrounded in an ongoing way by the texture that lies beyond the closure you have effected....

The modern state is a form of closure. Consider what has happened in Europe over the course of several centuries. Throughout much of European legal history, there were recognizably cosmopolitan states with ecclesiastical law, commercial law, and, in some measure, Roman law running across what are now state borders. There were many horizontal webs of pan-European law.... These horizontal webs of law ... suffered greatly in the process of the territorial and national closures of the seventeenth through twentieth centuries.

This process of political and legal closure had its precedents, of course. Before the contemporary state there were other forms of closure. We have had, in earlier times, closure around tribes as the major form of legal and political organization. Tribes have now lost much of their significance because the closure of the tribe has given way for many

describes as "a norm accepted and recognized by the international community of States as a whole as a norm from which no derogation is permitted and which can be modified only by a subsequent norm of general international law having the same character." Vienna Convention on the Law of Treaties art. 53, May 23, 1969, 8 I.L.M. 679, 1155 U.N.T.S. 331.

376. Glenn-KLR, supra note 364, at 743.

377. Hilary L. Lawson, Closure: A StORy OF Everything (2001). Lawson is an Oxfordeducated English philosopher whose journalistic and scholarly career flowered in the 1980s. Lawson founded the Institute of Art and Ideas in 2008 with the aim of making ideas and philosophy a central part of cultural life. 
people to other, more tempting forms of closure. But tribes are still with us, as shown by the fact that [US] state law [and Canadian provincial and territorial law] recognizes the law of aboriginal peoples. ...

Another example from the past: in feudal times we had closure around the manor. The manor was the basic form of organization of feudal societies. [Today, though,] the manor has lost a great deal, if not all, of its significance. It yielded to ongoing attraction of the texture that surrounded it. It gave way to city-states, so called because they were the product of a form of political and legal organization meant to be in large measure self-sufficient. The city-states and the manors then gave way to kingdoms. There were even so-called absolutist kingdoms, such as that of Louis XIV, the Sun King. But those kingdoms couldn't resist other forms of closure that emerged from the texture surrounding them. So we saw the emergence of the contemporary state as a territorially bounded exclusive source of law for what is meant (or imagined) to be a uniform population within it.

We are finding today that the contemporary state is losing its grip. States are tempted by texture beyond themselves.... [As a consequence], the contemporary state today is declining in influence. ${ }^{378}$

Beyond this concept of "closure versus texture"-and the progression by which each unit of political closures has yielded, one by one, to what Glenn calls the "ongoing attraction of the texture that surrounded it"Glenn offers one further conceptual perspective that I find directly relevant to a study of sovereignty and "nation-states" in today's world. ${ }^{379} \mathrm{He}$ explains the so-called "law of the excluded middle" and says that it is gradually (and properly) losing influence in favor of a more subtle and accurate view of the world:

Western lawyers and western people have been taught to think in terms of classical logic. There are so-called "laws of thought." [There is, for instance,] ... the "law" of the excluded middle: A or not-A. Between two contradictory propositions, say the classical logicians, there is no middle ground. This is very depressing news for lawyers, faced with the important task of finding some area of middle ground over a vast number of cases.

Why is it logically the case that there is an excluded middle? It flows from the basic assumptions of classical logic. Take me, for example. I am Patrick Glenn. Classical logic treats me as A, a much crisper notion than the real Patrick Glenn. From my perspective, the rest of the world is not Patrick Glenn, or not-A. Thus it becomes logically "Patrick Glenn" or "not-Patrick Glenn" and there is an excluded middle: there is nothing between "Patrick Glenn" and "not-Patrick Glenn." Why is that

378. Glenn-KLR, supra note 364, at 744-47 (citing LAWSON, supra note 377).

379. Id. at 746 . 
logically necessary? Because "not-Patrick Glenn" starts exactly at the (crisp) border of Patrick Glenn and goes on out forever; it is galactic in character. The "not-Patrick Glenn" eats up all possibility of a middle ground. Classical logicians tell us this is how we must think, once there has been formulation of initial, crisp and contradictory propositions, and the teaching of this logic has been very influential in efforts to construct the legal unity thought necessary for a nation-state. Kelsen relied on it explicitly, $\left[{ }^{380}\right]$ and codifiers were much influenced by it.

There are, however, what are being called the "new logics" in the world. [One assertion coming from the "new logics"] is that we needn't take classical logic and the "law" of the excluded middle as we have taken it. That is because a more subtle view of the world does not accept that boundaries are always crisp. Quantum physics is now telling us this, and we already know that normative propositions are always fuzzy in terms of their field of application. All need not be mutually exclusive. There can therefore be a many-valued logic, in which multiple truths can be sustained and a middle ground found between them. This is good news for lawyers, though they may have known it all the time.

To generalize: you can accept contradictions and live with them. You can accept a right to freedom of expression and a right to privacy and everything then depends on where particular cases are situated within the field defined by those contradictory general principles. Logicians are beginning to recognize that the real world is much subtler than a world composed of As and not-As. It really is possible, as legal practice tells us, to find included middles. ${ }^{381}$

Glenn draws on this "new logic" that permits the "included middle" in order to urge us "to think in terms of cosmopolitan logic" in order to get comfortable with the notion of a cosmopolitan state-one in which multiple nations and authorities coexist. ${ }^{382}$ This is the third of three key points that Glenn's account offers to us and that have prompted me to emphasize his work here. First, he confirms what I have already emphasized in this Article - that such familiar terms as "state" and "nation," along with "nation-state," "nationalism," "nationality," and even "sovereignty," are so definitionally confused and historically peculiar as to lead us away from a clear understanding of today's world rather than toward such an understanding. Second, all states in today's world are in reality "cosmopolitan states" (not "nation-states"), and those states that are more cosmopolitan (and more comfortable with that fact) are the states that are (in Glenn's estimation) most successful. Third, whatever "closure" we engage in for purposes of defining any unit of political

380. For this, Glenn cites Hans Kelsen, PuRE THEORY OF LAW 206 (Max Knight trans., 1989) (1960) (discussing "the Principle of the Exclusion of Contradictions").

381. Glenn-KLR, supra note 364, at 750-51 (citing KELSEN, supra note 380) (emphasis added).

382. Id. at 752 . 
organizations state - such as the tribe, or the manor, or the city-state, or the (cosmopolitan) state - is necessarily artificial and tentative in at least two ways: (i) as a practical matter, the unit defined by such a process of "closure" has a tendency to yield to what Glenn calls the "ongoing attraction of the texture that surround[s] it"; and (ii) as a logical matter, the law of the "included middle" asserts that boundaries are not always crisp, and therefore we should be neither surprised nor discomfited at the prospect of multiple nations and authorities coexisting within a particular state. $^{383}$ Borders are porous in many or most respects, and that is a good thing.

Let me move briefly from politics to earth science. We can see in these three points emerging from Glenn's writing on the cosmopolitan state (as a political matter) a very close similarity to more contemporary views of the ecosphere. Some scientists and philosophers have urged recently, especially in view of our growing knowledge about the vastness of the universe and the tininess of those single-celled organisms that comprise the bulk of life on Earth, that we examine the scale of our perception and consider what new insights might be generated through shifting our scale of perception. ${ }^{384}$ From our usual perspective from inside the pedosphere - that is, from inside the system of all the organisms, soils, water, and air lying at the interface of the lithosphere, the atmosphere, the hydrosphere, and the biosphere ${ }^{385}$ - we typically think of some parts of Earth as living and others as non-living. For instance, animals and plants

383. See id. at $746-52$.

384. See Wes Jackson, Aubrey Streit Krug, Bill Vitek \& Robert Jensen, Transforming Human Life on Our Home Planet, Perennially, 2 ECOLOGICAL CITIZEN (2018), https://www.ecologicalcitizen. net/pdfs/v02n1-08.pdf [https://perma.cc/XA64-9WE7]. These authors draw on the writings of Stan Rowe, a geo-ecologist and environmentalist who worked as a research forester with Forestry Canada for nineteen years and also served as Professor of Plant Ecology at the University of Saskatchewan. Rowe urged his readers to stop thinking about "organisms as possessing life" and start thinking instead of "life as possessing organisms." HEAD-2017, supra note 4, at 387. In discussing the relationship between life, the ecosphere, and organisms, Rowe explains that "[f]or thousands of years, humans have been viewers immersed in the Ecosphere," and thus unable to see clearly that the Ecosphere is in fact an entity that itself has life. J. Stan Rowe, Biological Fallacy: Life = Organisms, ECOCENTRISM (1992), http://www.ecospherics.net/pages/RoBiolFallacy.html [https://perma.cc/KW2Z-CJXD]. (first published in 42 BIOSCIENCE 6 (1992)). However, Rowe clarifies, the Ecosphere "is not a superorganism; it is supraorganic: a higher level of organization than plants and animals, including people." Id. Moreover, he insists, the world is not riven with competition: "The lively Ecosphere gives the lie to those who see the world's reality as little more than a competitive arena, for without compliant cooperation among its multitudinous parts the diversifying creativity of the planet could not have evolved nor could its overall homeostasis continue." Id. For biographical information about Stan Rowe and copies of some of his works, see About the Authors and Translators, ECOCENTRISM, http://www.ecospherics.net/pages/aboutauthors.html\#rowe [https://perma.cc/8ETM-FF9R].

385. By some definitions, the pedosphere-from Greek $\pi \varepsilon ́ \delta$ ov (pedon, which is "soil" or "earth") and $\sigma \varphi \alpha i p \alpha$ (sfaíra, which is "sphere") - is the outermost layer of the Earth that is composed of soil and subject to soil formation processes. For more details on the pedosphere, see generally ELISSA Shart LeVine, The Pedosphere as a Hub (2001). 
seem dynamic but the environments we live in, with their stones and gases and water and wind, seem non-living. Likewise, we think we can easily draw lines between different "spheres" of the Earth as a structure, such as the biosphere versus the atmosphere. However, this "from the inside" viewpoint is only one perspective. When we take a view not from the inside but rather from the outside, we can start to realize how all components inside the system interact in extraordinarily complex ways. We can start to imagine how life is a property of the whole system, rather than merely a property exhibited by just some parts of the system.

One thing that I believe we can learn from the writings I highlighted above from Glenn, d'Entrèves, and Hechter, as well as from several of the writers I referred to in Part I of this Article relating to sovereignty, is that the scale of our perception has a crucial bearing on how we understand the social and political world. Just as we can draw lines between different "spheres" in the natural world, we can do so in the political world as well by using such familiar terms as "state," "nation," "sovereignty," and the like. Yet in both cases, we must be careful not to let those lines and definitions lead us away from a clear understanding of today's world. Likewise, just as a view of the natural world "from the outside" helps us realize how all natural systems on Earth interact in complex and interdependent ways, a view of the political world "from the outside" helps us realize how all political systems - at such various (artificial and tentative) levels as the village, the region, the state, or the Earth as a whole - interact in complex and interdependent ways. Therefore the more knowledgeable and appreciative we are about those complexities and interdependencies, the more successful we can be in our efforts at acting cooperatively to address global problems that we share.

The global problems that I concentrate on in my research are those of agricultural and ecological degradation. It happens, therefore, that the analogies I am trying to draw here-between (i) new and well-considered perspectives on global political reality and (ii) new and well-considered perspectives on the Earth's natural systems - are particularly close and clear ones. One element of them both that I have not yet adequately emphasized concerns land territory. I turn now to that element.

\section{IID. Territorial Integrity, Ownership, and Responsibility}

Thus far in this Article, I have dealt somewhat separately with the concepts of sovereignty and the nation-state. In fact, Part I of this Article has dealt with the first of these, whereas Part II has dealt up to now mainly with the second one. In one especially important respect, though, the two concepts of sovereignty and the nation-state-fuzzy and unsatisfying as 
those concepts may be - coincide: territory. Consider these points:

- The definition of a state virtually always includes territory as an element. For instance, the Montevideo Convention of the 1920s - more formally known as the Convention on the Rights and Duties of States - offers a definition of "state" that has become very widely accepted and cited: "The state as a person of international law should possess the following qualifications: (a) a permanent population; (b) a defined territory; (c) government; and (d) capacity to enter into relations with the other states." 386

- The definition of sovereignty in international law likewise is inextricably bound up with the idea of territory. Consider this definition, drawing from some of the most recognized and respected authorities in international law: "The exercise of . . . supreme authority by a State over its own territory is known in International Law as 'territorial sovereignty'.... Territorial sovereignty signifies ownership and possession of a territory, which entitles a State to exercise its authority and jurisdiction over the territory." 387

- A similar characterization of the central role played by territory appears in this excerpt: "The principle whereby a state is deemed to exercise exclusive power over its territory can be regarded as a fundamental axiom of classical international law." 388

- Territory figures prominently in the descriptions of

386. Montevideo Convention on the Rights and Duties of States, Dec. 26, 1933, 165 L.N.T.S. 19 (emphasis added). The Montevideo Convention is technically binding as a matter of treaty law only among its sixteen parties, all of which are in the Americas and all of which ratified it in late 1933. However, as many international law authorities have asserted, the definition of a state found in the convention codifies customary international law and is therefore binding on all states. See, e.g., D.J. HARRIS, CASES AND MATERIALS ON INTERNATIONAL LAW 99 (6th ed. 2004).

387. Walid Abdulrahim, State Territory and Territorial Sovereignty, https://sites.google.com/ site/walidabdulrahim/home/my-studies-in-english/6-state-territory-and-territorial-sovereignty [https://perma.cc/3NR8-5WSH] (emphasis added) (citing L. OPPENHEIM, 1 INTERNATIONAL LAW 563 (R.J. Jennings \& A.D. Watts eds., 9th ed. 1992); J.L. BRIERLY, LAW OF NATIONS 142 (4th ed. 1949); M. N. SHAW, INTERNATIONAL LAW, 411-26 (5th ed. 2003)).

388. Malcolm N. Shaw, The International Court of Justice and the Law of Territory, in THE DEVElopment OF INTERNATIONAL LAW BY THE INTERNATIONAL COURT OF JuSTiCE 151 (Christian J. Tams \& James Sloan eds., 2013) (emphasis added). Shaw goes on to assert that " [t]he development of international law upon the basis of the exclusive authority of the state within an accepted territorial framework has meant that territory has become "perhaps the fundamental concept of international law'." Id. (quoting from D.P. O'Connell). He further notes that despite recent political, technological, and economic changes, "it is fair to say that territorial sovereignty remains at the core of international law." Id. at 152. 
sovereignty offered by the various authorities I cited in Part I of this Article. ${ }^{389}$

- The UN Charter reflects the notion of territorial sovereignty in Article 2(4), which is widely regarded as a centerpiece of the collective-defense system that the Charter establishes, and as being reflective of the principle of sovereignty: "All Members shall refrain in their international relations from the threat or use of force against the territorial integrity or political independence of any state." 390

In short, traditional international law views control over territory as being critical to the existence of a state. Such control over territory seems to be, in fact, a sine qua non of both statehood and sovereignty.

Like those broader concepts, however, the notion of territory-and particularly the assertion that a state has exclusive or comprehensive control over what occurs in "its" territory-has come under intense scrutiny, especially in recent years. Academic literature on the topic includes numerous works reflecting a reevaluation of the roles that territory and territorial control play in international law and in the concepts of sovereignty and the state. ${ }^{391}$ While this expansive literature covers many topics, I wish to draw attention to only three, because they have special significance to the subjects that dominate my current research work-agricultural reform and ecological protection at the global level-

389. See, e.g., supra notes 46 (Bartelson), 123 (Krasner), 171 (Heller and Sofaer), and 378 (Glenn) and accompanying text.

390. U.N. CHARTER art. 2, $\uparrow 4$ (emphasis added).

391. For some especially significant contributions to the literature, see the work of Marcelo Kohen, including Marcelo G. Kohen, Is the Notion of Territorial Sovereignty Obsolete?, in BORDERLANDS UNDER STRESS 35 (Martin Pratt \& Janet Allison-Brown eds., 2000) [hereinafter Kohen-2000]; MARCElo G. KoHEN, TERRITORIALITY AND INTERNATIONAL LAW (2016). In the first of those works, Kohen makes this assertion: "It is no coincidence that 'sovereignty' and 'territory' are inextricably linked terms: the events that led to the emergence of the modern state had as their mainstay the territorial basis of the exercise of power." Kohen-2000, supra, at 35. Despite this, Kohen explains, territory and sovereignty increasingly need to be viewed separately, partly because sovereignty itself has undergone change as a concept and a practice: "Globalisation, interdependence and integration are contemporary phenomena which supposedly render the traditional concept of sovereignty obsolete. Indeed, more and more of the powers which pertained to states not so long ago are today vested in international institutions." Id. Some scholars, he continues, "refer to a new notion, 'intersovereignty", in order to explain the relinquishment of sovereignty by states in fields of common interest, where the decisions are shared with the other members of the international community." Id. (citing a 1988 work by Seara Vaszquez). "Moreover, territorial sovereignty is traditionally confined to one particular status: the state's spatial sphere of jurisdiction. This definition does not take into account other statuses ...." Id. at 37. Indeed, Kohen asserts, even though it is true that " $[t]$ he display of state power over a territory is normally the main manifestation of sovereignty, . . it is not the main characteristic of sovereignty. A state can control territory without being its sovereign." Id. In short, the linkage between territory and sovereignty is less obvious and more nuanced than in earlier times. 
and also, as it happens, at the personal, individual level. The three topics are territorial integrity, territorial control, and territorial responsibility. I will deal with each point briefly.

What is meant by territorial integrity? As noted in the bullet-point list I offered just above, ${ }^{392}$ the UN Charter makes express reference to territorial integrity. In international law, this Charter provision has been viewed largely as bearing on the stability of national boundaries, as reflected in this comment in a "user's guide" to a UN-initiated treaty:

Article 2(4) of the UN Charter requires all member states to 'refrain in their international relations from the threat or use of force against the territorial integrity or political independence of any state, or in any other manner inconsistent with the purposes of the United Nations.' While the Charter does not define what it actually means by 'territorial integrity', it is now well recognised and reflects the fundamental international objective in the stability of boundaries. In 1986, a chamber of the ICJ considered the principle as one of general international law. This view was confirmed by the 'Badinter Commission' regarding the former Yugoslav republics, stating that 'whatever the circumstances, the right of self-determination must not involve changes to existing frontiers at the time of independence.' 393

If we view the notion of "territorial integrity," however, from the perspective of agriculture and ecology, surely a broader definition is warranted than what appears in these UN Charter references. Let us construct such a broader definition by considering carefully each of the components - that is, the word "territory" and the word "integrity," starting with the latter.

Dictionaries typically give two main definitions for "integrity." The first definition focuses on ethical behavior and often refers to honesty, rectitude, good character, righteousness, virtue, decency, and truthfulness. The second definition is usually captured in the word "wholeness," to convey the sense of a complete, entire, undamaged, and unimpaired condition-with such synonyms as "soundness," "unity," "coherence," and "solidarity." 394 It is the second of these definitions that has more

392. See supra note 390 and accompanying text.

393. Territorial Integrity, UN WATERCOURSES CONVENTION ONLINE USER'S GUIDE, http://www.unwatercoursesconvention.org/the-convention/part-ii-general-principles/article-8-general -obligation-to-cooperate/8-1-3-territorial-integrity/ [https://perma.cc/PZ34-GRBT] (citing ICJ opinions and other authorities).

394. These and similar definitions and synonyms can be found in a range of online sources, including those supplied by Merriam-Webster. See Integrity, MERRIAM-WEBSTER, http://www.merriam-webster.com/dictionary/integrity [https://perma.cc/UFV4-HLHD] (last visited Mar. 30, 2019). 
relevance for territorial integrity in this context.

The word "integrity" comes from the Latin adjective integer, which itself combines three elements from Latin:

- the prefix in-, which in this sense corresponds to English "un-", having a negative force, as in the words "indefensible" or "inorganic";

- $\quad$-teg-, which is the combining form of tag-, which in turn is the base of tangere, "to touch"; and

- the suffix $-e r{ }^{395}$

Taken together, these three elements create a literal meaning for "integer" of "untouched" (in-teg-er = un-"touch"-ed) and related meanings of "whole" or "complete" - as can be seen in the English word "integer" as referring to "a whole number" as opposed to a fraction-and also conveying other related meanings of "untainted" and "upright." 396 Some sources would extend the connotation of "integer" to include "unhurt," "unchanged," "sound," "fresh," "whole," "entire," "pure," and even "honest" (which brings this second definition of "integrity" close to the first definition focusing on ethical behavior). ${ }^{397}$ It is this array of meanings for "integer" that gives rise to the "wholeness" definition of "integrity" that I explained two paragraphs before this one.

It is with these meanings in mind for "integer," and for the word "integrity" emerging from it, that we can specify what the word "integrity" might mean in the context of international law as it involves such concepts of sovereignty, the state, and most particularly "territorial integrity." This requires that we examine the term "territory." In doing so, we can place the notion of "territorial integrity" in a broader perspective than one focusing mainly on the stability of national boundaries, as reflected in Article 2(4) of the UN Charter.

The term "territory" carries various meanings that typically combine two main elements: (i) an area of the Earth's surface (usually land but sometimes water) and (ii) a sense of belonging or ownership. An online search yields such definitions as these for "territory":

- An area of land, or sometimes sea, that is considered as belonging to or connected with a particular country of person.

395. Integer, ONLINE ETYMOLOGY DiCTIONARY, https://www.etymonline.com/word/integer [https://perma.cc/XR55-DJZ8] (last visited Mar. 30, 2019) (noting that the term first appeared in English around 1500 as a noun and in the 1570 s as a noun).

396. Id.

397. See Integer, WiKTIONARY, en.wiktionary.org/wiki/integer [https://perma.cc/J4NV-SL2M] (last visited Mar. 30, 2019). 
- An area of land under the jurisdiction of a ruler or state.

- Any separate tract of land belonging to a state.

- The area that an animal defends against intruders, especially of the same species. ${ }^{398}$

- A field or sphere of action, thought, etc.; the domain or province of something. ${ }^{399}$

- Any tract of land; a region or district.

Many of those definitions have strong political content, ${ }^{400}$ but some of them-the last one in the above bullet-point list, for instance-can be regarded as quite general, having mainly a geographical content. Interestingly, the next-to-last item on that bullet-point list departs from the pattern of the others in its omission of any reference to a physical location or area; instead, it focuses on a subject-matter.

According to some on-line sources, the word "territory" appeared in Middle English during the first half of the fifteenth century, drawn from the Latin term territorium, meaning the land around a town. ${ }^{401}$ The derivation of the term territôrium, however, is subject to some uncertainty. One theory is that territōium comes from terra ("land"), -tor ("er," used for forming agent nouns,) and ium ("ity," for forming abstract nouns). Another theory also identifies terra ("land") as a source for territōium but asserts that the latter portion of the word comes from -orium, a suffix denoting place. A third theory suggests a derivation from terrere, which means "to frighten"; in this sense territōrium would mean "a place from which people are warned off." 402 A fourth theory focuses on torium as the root giving rise to such words "as 'tower', 'tour', and 'torre', which conveyed in Medieval English, Old French, Italian, and Spanish the meaning of both 'a well-rounded building' and 'a position of strength'.",403

This close attention to etymology reveals, then, a penchant for

398. According to one source, this use of "territory" - meaning an area defended by animalsdates only from 1774. Douglas Harper, Territory, ONLINE ETYMOLOGY DiCTIONARY, https://www.etymonline.com/word/territory [https://perma.cc/QB45-2E3M] (last visited Mar. 30, 2019).

399. An illustration of this meaning would appear in the phrase "for Donald Trump, unfettered self-adulation is familiar territory."

400. For instance, the notion of "jurisdiction" (a legal and political concept) often figures prominently in definitions of "territory," and especially in the types of territory appearing on lists of related definitions. These include capital territory, federal territory, overseas territory, dependent territory, disputed territory, and occupied territory.

401. See Territory, DICTIONARY.COM, https://www.dictionary.com/browse/territory [https://perma.cc/HV95-G65W] (last visited Mar. 30, 2019). Another source dates the appearance of "territory" to the late fourteenth century. See source cited supra note 398.

402. See supra note 398.

403. Daniel-Erasmus Khan, Territory and Boundaries, in THE OXFORD HANDBOOK OF THE History OF INTERNATIONAL LAW 231 (Bardo Fassbender \& Anne Peters eds., 2012). 
regarding territory as a geographic region accompanied by some sense of belonging or ownership. I believe that the common understanding of such a sense of belonging or ownership is that it is the geographical region, which is the thing that is owned or that "belongs to" some human institution such as a state. In other words, we typically think of a geographic area as "belonging to" a state, in the way that we typically think of a parcel of land "belonging to" and being "owned by" an individual human being or a group of private persons.

What if we turn the tables? I suggest that we try thinking of the sense of "belonging" and "ownership" as running in the other direction. Perhaps it is easier to think in this way by examining first the notion of private ownership of a parcel of land and explore two related propositions. The first is that there is a logical and legal flaw in considering a person to be "the owner of a parcel of land" at all. The second is that the sort of ownership or "belonging" involved in the case of a parcel of land runs from the person as the thing that in some sense "belongs to" or is "owned by" the land, instead of the other way around.

In my earlier book on international law and agroecological husbandry, I emphasized that property claims over land have substantially changed, as a legal matter, with the passage of time. ${ }^{404}$ In particular, I summarized these views from Sanjay Kabir Bavikatte, as expressed in his book Stewarding the Earth: Rethinking Property and the Emergence of Biocultural Rights:

The understanding of property in law has never been constant, and discussions around the concept are among the most contested areas of jurisprudence. In fact, if we approach law as politics, then the discourse of property is perhaps the epicentre. The very notion of personhood, and hence the juridical subject in liberal democracies, is based on an assumption that a right to property is integral to what we understand as 'person'... [since such liberal democracies typically characterize] personhood as incorporating a bundle of individual rights including the right to property....

[Some modern observers, however, are attempting to correct some major] fallacies regarding property in capitalist societies. . . .

[One of these fallacies arises] where property is understood as a thing rather than a right. The influential Canadian political scientist C. B. Macpherson in his analysis of property notes: 'In current common usage, property is things; [but] in law and in the [works of legal] writers, property is not things, but rights, rights in or to things'... . The reason

404. See HEAD-2017, supra note 4, at 309-12. 
why [this is a fallacy is that it is] a product of historical circumstances, specifically of the dominance of market economies, which ... [despite their recent development] are passed off as ahistorical and natural. ${ }^{40}$

Importantly, the description that Bavikatte gives in this passage of the "notion of personhood" applies equally to states as to individuals: it is a fundamental tenet of international law that statehood (like "personhood," in Bavikatte's formulation) is seen as "incorporating a bundle of . . . rights including the right to property." "406 After all, as noted above, the standard definition of a "state" includes territory as one of its four elements. ${ }^{407}$ Therefore, the first of the two "fallacies" that Bavikatte identifies-the fallacy of understanding property as a thing rather than a right — can exist in the case of territorial claims made by states as well as in the case of individual property claims. In exploring that fallacy further, Bavikatte quotes Macpherson in pinpointing when the first of these developmentsthat is, the equating of property with things rather than rights - arose:

The change in common usage, to treating property as things themselves, came with the spread of the full capitalist market economy from the seventeenth century on, and the replacement of the old limited rights in land and other valuable things by virtually unlimited rights. As rights in land became more absolute, and parcels of land became more freely marketable commodities, it became natural to think of the land itself as property. ${ }^{408}$

Put in the context of parcels or regions of land, correcting this commodification-of-land fallacy involves returning to a way of thinking in which property is not the land itself but certain rights in the land. Making this correction - whether in the case of individual property or in

405. Sanjay Kabir Bavikatte, Stewarding the Earth: Rethinking Property and the EMERgEnCE OF Biocultural Rights 116, 116 n.2, 117 (2014) (citing C.B. Macpherson, The Meaning of Property, in, Property: MaInstream and CRITICAl Positions 2 (C.B. Macpherson, ed., 1978)). Bavikatte is an environmental lawyer who founded the international organization Natural Justice, has served as legal advisor to several African countries, and has worked through the United Nations and other entities in coordinating grassroots initiatives with indigenous peoples on environmental matters. Id. at 267.

406. Id. $116,116 \mathrm{n} .2$.

407. See supra note 386 and accompanying text. The phrase "bundle of entitlements" is commonly used in the context of international law. See, e.g., Anthony D'Amato, Is International Law Really 'Law'?, Nw. U. SCH. OF L. SCHOLARLY COMMONS 1, 12 (2010), http://scholarlycommons.law. northwestern.edu/cgi/viewcontent.cgi?article $=1102 \&$ context=facultyworkingpapers [https://perma.cc /JEM2-DNFV] ("As a construct of international law, a nation is nothing more nor less than a bundle of entitlements, of which the most important ones define and secure its boundaries on a map, while others define its jurisdictional competency and the rights of its citizens when they travel outside its borders.").

408. Bavikatte, supra note 405, at 118 (quoting C.B. MACPHERSON, THE MEANING OF PROPERTY $7-8(1978))$. 
the case of a state's "territory" - clears the way for a more (accurately) pluralistic and disaggregated view in which various rights in property can be owned by various entities. At the level of international law, the entities generally recognized as having legal "personality" are (i) states and (ii) international organizations - by which I mean such institutions as the United Nations, the International Monetary Fund, the International Bank for Reconstruction and Development, the World Trade Organization, and others that have states as members-are not incorporated within any particular state, have a set of privileges and immunities that resemble those of states, and are governed by treaties that give them (either explicitly or implicitly) treaty-making and other powers.

It follows from this analysis that a state is not properly seen as "owning" the geographical region that denominates the territory that helps define it but should instead be seen as possessing a great many rights - but not all rights - to exercise authority within that geographical region. Expressed differently, it is certain rights, but typically not all rights, that "belong" to a state in "its" territory. Indeed, the rich variety of political arrangements described in the Tibet-related book that I referred to above in Section IC2 of this Article (Regional Autonomy, Cultural Diversity and Differentiated Territorial Government) illustrates how common it is to find blended, mixed-and-matched political authorities to exist within any particular geographic region, despite the fact that such region is regarded as being part of the territory of a particular state.

Having emphasized in the preceding paragraphs that there is an analogy between (i) the rights of a person over land and (ii) the rights of a state over "its" territory, I should emphasize that the forms of control and authority that a state has over land are in fact more complicated than the discussion thus far suggests. In explaining key details of privately-owned land, publicly-owned land, and state territory, Ali Khan offers these historical and definitional observations:

To clarify the concept of territory as an essential element of the sovereign state, Grotius invokes Seneca and others to distinguish between ownership and sovereignty. Ownership is tied to the estate; sovereignty is tied to the territory. The land an individual owns constitutes a private estate. Public estates are the land the state owns. All private and public estates within a state's borders jointly make up the territory of the state. With respect to public lands, the state possesses both ownership and sovereignty while over property the state has sovereignty without ownership. Thus even if every inch of land is privately owned, the territory remains subject to state sovereignty. This is so because the same land can be both an estate and a piece of the state's territory, simultaneously containing the rights of both the owner and the state. The ownership of an estate may be transferred from one person to another, 
even from the individual to the state or vice versa. But changes in ownership do not affect state sovereignty over the territory. ${ }^{409}$

Ali Khan then explains that these legal principles about land ownership and territorial claims "might be derived from the feudal principle that the king is the ultimate owner of all land." 410 In any event, the same general proposition of ultimate priority prevails in the international legal concept of a state's territory: a private owner's rights in an estate are in some measure always subject to the state's territorial sovereignty. Or, as Ali Khan expresses it, "the state's right derived from territorial sovereignty is superior to the owner's right derived from estate ownership." 411 As an illustration of this, Ali Khan reminds us that "[t]he state may lawfully forbid the owner from committing any crime on the estate." 412

In short, the rights of a state over land, in today's system, comprise two broad categories: (i) the state may possess certain rights of ownership (speaking technically, as noted above, what is owned is a set of rights, not the land itself), and (ii) the state will in any event possess rights inherent in its territorial claim to that land as falling with its recognized jurisdiction. The second of these categories of rights over land does not apply, of course, to individuals, although the first category does. What I wish to posit is that the second category of rights might be possessed not only by the so-called "nation-states" of the sort that have dominated the world for the past four centuries or so-entities that we might better call "anthro-states" to reflect Patrick Glenn's insistence that there is no such thing as a "nation-state" 413 _ but also by another form of political entity that I call the "eco-state." 414

A key rationale for such an innovation is that placing such authority over land not with traditional "nation-states" but rather with eco-states would facilitate a more effective program of restoration and preservation of the natural environmental endowments of the land - that is, their soils (pedosphere), their water (hydrosphere), their air (atmosphere), and their biodiversity (biosphere). This closer attention to restoration and protection would, in turn, involve a keen acknowledgement that the rights and interest in these natural environmental endowments and features

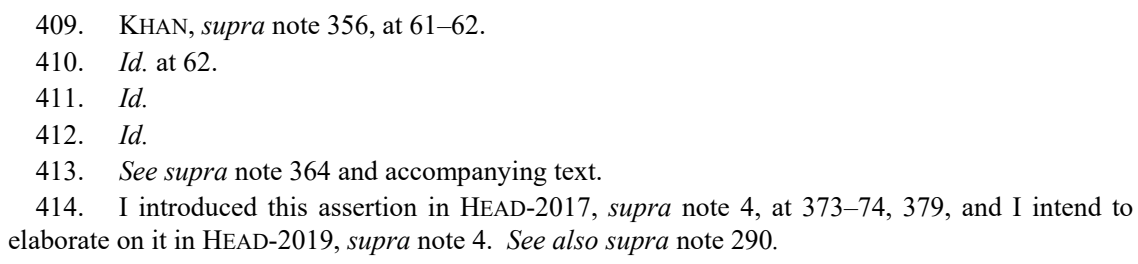


"belong" not just to the currently-recognized "owners" but to future generations of humans and to present and future generations of other species.

Let me turn now to the second logical and legal flaw I noted above: the mistake of thinking that the sort of ownership or "belonging" involved in the case of a parcel of land always runs from the land as the thing that in some sense "belongs to" or is "owned by" the person-or, at the international level, by the state - instead of the other way around. Here is the issue expressed in an overly-simplified form as it would apply to my wife and me: Do we own the eighty-eight acre tract of land we live on southwest of Lawrence, Kansas, or does it own us?

Recall that the title song in the play (and movie) Oklahoma includes these lines: "We know we belong to the land, And the land we belong to is grand." Al15 Leopold expressed a similar sentiment in lamenting the paltry efforts to protect land from degradation by humans:

Conservation is getting nowhere because it is incompatible with our Abrahamic concept of land. We abuse land because we regard it as a commodity belonging to us. When we see land as a community to which we belong, we may begin to use it with love and respect. ${ }^{416}$

Countless others have expressed a similar notion - that as humans we belong to, and are part of, and cannot live separately from, the rest of the natural world in which we have our being. ${ }^{417}$ What I wish to emphasize, though, in the present discussion of territorial sovereignty is this: we should attempt to regard a state as "belonging to" its territory instead of

415. Restored Cinema Footage, Oklahoma! - Oklahoma (1955), YouTuBE (Sep. 3, 2017), https://www.youtube.com/watch?v=XdymQslE1xs [https://perma.cc/J4XF-59P9].

416. Aldo Leopold, A SAND County AlmanaC viii (1949) (emphasis added).

417. The interdependence of humans in society was taken for granted in earlier times. Stephen Greenblatt's description of life in fifteenth century Europe reflects this sense of interdependence: "An isolated individual, considered outside the structures of family and occupation, made very little sense. What mattered was what you belonged to or even whom you belonged to.... The household, the kinship network, the guild, the corporation - these were the building blocks of personhood" within the societies of that time. STEPHEN GREENBLATt, THE SWERVE: HOW THE WORLD BECAME MODERN 15 16 (2011). Greenblatt then explants a consequence of this social structure: "Independence and selfreliance had no cultural purchase; indeed, they could scarcely be conceived, let alone prized. Identity came with a precise, well-understood place in a chain of command and obedience." Id. at 16. While numerous attributes of individual human independence - and human rights - are to be celebrated in modern society, it is worth bearing in mind that humans must be integrated into, and not pretend to be independent from, the natural world and its systems and limitations. Therefore, to modify Greenblatt's formulation with an ecological emphasis: "The ecosystem, the network of species, and the processes they contribute to - these are the building blocks of personhood within the natural world.... Identity comes with a precise, well-understood place in a system of physical and biological parameters and possibilities." It is in that sense that, as Leopold expressed it, we should "see land as a community to which we belong." LEOPOLD, supra note 416, at viii. Indeed, we should see the entire ecosphere as a community to which we belong. 
the other way around. More precisely, the human population living in a particular ecosystem should regard itself as a part of that ecosystem, in the same way that other species of plants and animals must do. From an ecological standpoint, no species (or individual within that species) can long survive if it does not harmonize its behavior with the fundamental realities of that ecosystem where it lives and which it shares with other species.

Hence, as a conceptual and legal matter, the notion of "territorial sovereignty" should be modified in several ways. Let me highlight five. First, this sort of "sovereignty" should not be equated with "ownership" in the sense of owning land; instead, the more technically-accurate notion of owning rights in land should be adopted, thus reflecting the fact that some rights in the land-some aspects of sovereignty over a territory-are allocated to one set of rights-holders and others are allocated to a different set of rights-holders. Rights to enjoy the fruits of the land, for instance, might be held by persons other than those who hold the right to sell it.

Second, as a corollary to the point just made, territorial sovereignty should not be regarded as territorial license or unfettered discretion on the part of the rights-holder to treat the land, and the ecosystems it comprises, in an abusive way. Just as, in Ali Khan's words, "[t]he state may lawfully forbid the owner from committing any crime on the estate," 418 likewise the state itself must be refrained, or be constrained, from degrading any aspects of those ecosystems. Expressed differently, territorial sovereignty must be regarded as involving as much responsibility for land as it does rights over land.

Third, the specific aspects of territorial sovereignty that relate directly to its "environment," construed broadly, should fall within the authority of eco-states, as I have referred to them briefly above, rather than within the authority of the traditional entities we commonly refer to as nation-states. Naturally, distinctions will be difficult to make in some respects as to what does and what does not relate directly to the environment of a region.

Fourth, inasmuch as placing environmental rights and responsibilities with eco-states will allow giving closer attention to restoration and protection, it must also facilitate an acknowledgement that natural environmental endowments and features "belong" not just to the currentlyrecognized "owners" but to future generations of humans and to present and future generations of other species. In this manner, a proper conceptualization of sovereignty should recognize both intergenerational and interspecies interests and equities.

418. KHAN, supra note 356 , at 62 . 
Fifth, using the term "territorial sovereignty," and analogizing it to property ownership, should not stand in the way of an effort to regard a state, or more precisely its people, as "belonging to" its territory instead of the other way around. A human population in an ecosystem must, in the words of the song Oklahoma (given above), "know we belong to the land." Terminology matters; concepts matter. Just as the well-worn term "nationstate" is deeply misleading, the term "territorial sovereignty" can be misleading.

\section{CONCLUDING OBSERVATIONS}

I have analyzed in this Article (i) the doctrine of sovereignty and (ii) the so-called nation-state that purports to possess and exercise such sovereignty. By means of this analysis I have emphasized how poorly certain concepts rooted in sixteenth- and seventeenth-century Europe serve the needs of today's world, and indeed how in many ways they stand in the way of effective governance, especially relating to environmental issues. Many of the observers whose work I have examined and summarized here criticize these hoary concepts so strenuously as to recommend abandoning entirely both the concepts and the terms that name them.

My approach is only slightly less drastic: since the terms "sovereignty" and "state" have such recognizable stature in the language of international law and politics, we might usefully retain them, at least temporarily, but also offer revised versions of each that will encompass new elements aimed at refashioning them for today's world. In that respect, I have introduced the concepts of "pluralistic sovereignty" (as distinct from the "monolithic sovereignty" that I described in Part I of this Article) and the "eco-state." Thus far, I have only sketched their general contours. Their elaboration is central to my larger research project. ${ }^{419}$

419. As noted above, I have introduced this assertion in HEAD-2017, supra note 4, at 373-74, 379 , and I intend to elaborate on it in HEAD-2019, supra note 4. For my observations about the applicability of the "eco-state" concept to the Mediterranean Basin and similar ecoregions elsewhere in the world, see John W. Head, A Mediterranean Biome Eco-State: Reorienting Sovereignty in the Mediterranean Basin and its Four Global Correlatives, 10 MEDITERRANEAN REV. 113-44 (2017). 